EPIDEMIOLOGIA COMPARATIVA ENTRE A HELMINTOSPORIOSE E A FERRUGEM DA FOLHA DO TRIGO: ESTUDOS MONOCÍCLICOS, POLICÍCLICOS E DE SIMULAÇÃO

GISELE ABIGAIL MONTAN TORRES

Engenheiro Agrônomo

Orientadora: $\operatorname{Prof}^{\mathrm{a}} \mathrm{Dr}^{\mathrm{a}}$ LILIAN AMORIM

Dissertação apresentada à Escola Superior de Agricultura "Luiz de Queiroz", da Universidade de São Paulo, para obtenção do título de Mestre em Agronomia, Área de Concentração: Fitopatologia.

P I R A C I C A B A

Estado de São Paulo - Brasil

Julho - 1996 


\section{Dados Internacionais de Catalogação na Publicação (CIP) DIVISÃO DE BIBLIOTECA E DOCUMENTAÇÃO - Campus “Luiz de Queiroz"/USP}

Torres, Gisele Abigail Montan

Epidemiologia comparativa entre a helmintosporiose e a ferrugem da folha do trigo: estudos monocíclicos, policiclicos e de simulação / Gisele Abigail Montan Torres. - - Piracicaba, 1996.

$117 \mathrm{p}$.

Dissertação (mestrado) - - Escola Superior de Agricultura Luiz de Queiroz, 1996.

Bibliografia.

1. Epidemiologia - Região tropical - Modelo 2. Ferrugem alaranjada em trigo Epidemiologia 3. Helmintosporiose do trigo - Epidemiologia I. Titulo

$$
\begin{gathered}
632.44 \\
\text { CDD } 633.44 \\
633.11
\end{gathered}
$$


EPIDEMIOLOGIA COMPARATIVA ENTRE A HELMINTOSPORIOSE E A FERRUGEM DA FOLHA DO TRIGO: ESTUDOS MONOCÍCLICOS, POLICÍCLICOS E DE SIMULAÇÃO

GISELE ABIGAIL MONTAN TORRES

Aprovada em: 29.08.1996

Comissão julgadora:

$\operatorname{Prof}^{\mathrm{a}} \mathrm{Dr}^{\mathrm{a}}$ Lilian Amorim

ESALQ/USP

Prof. Dr. Armando Bergamin Filho ESALQ/USP

Dr. Mário José Pedro Júnior IAC - Campinas

hilian for 2 . Prof $^{\mathrm{a}}$ Dr $^{\mathrm{a}}$ LILIAN AMORIM

Orientadora 
Dedico ao Luciano, meu marido, pelos momentos que deixamos de conviver durante a realização deste trabalho, e aos meus pais, Fredy Joel e Maria Aparecida, e irmãos, Ana Gabriela, Rafael e Raquel pelo amor, amizade e apoio constantes. 


\section{AGRADECIMENTOS}

À Prof ${ }^{\mathrm{a}} \operatorname{Dr}^{\mathrm{a}}$ Lilian Amorim, pela orientação e incentivo.

Ao Prof. Dr. Hiroshi Kimati, pelo apoio e amizade.

Ao Prof. Dr. Armando Bergamin Filho, pelas sugestões.

Aos engenheiros agrônomos Marcelo Giovanetti Canteri e Nelson Freire Machado, por tornarem possível a realização dos ensaios de campo na área experimental da Batavo, em Ponta Grossa.

Ao Prof. Dr. Tasso Leo Krügner, pela redação do Summary.

À bibliotecária Eliana Maria Garcia Sabino, pelo auxílio na organização das referências bibliográficas.

Aos professores e funcionários do Departamento de Fitopatologia, pela atenção com a qual sempre pude contar.

Aos colegas do Curso de Pós-Graduação em Fitopatologia, especialmente aos epidemiologistas Cláudia, Marcelo, Marilene, Marise, Maristella e Renato, pela convivência.

À FAPESP, pela concessão da bolsa de estudos.

A todos que direta ou indiretamente contribuíram para a realização deste trabalho. 


\section{SUMÁRIO}

Página

LISTA DE FIGURAS ......................................................... viii

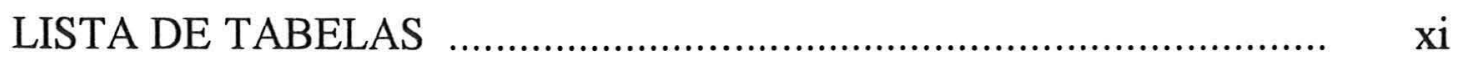

APÊNDICE .......................................................................

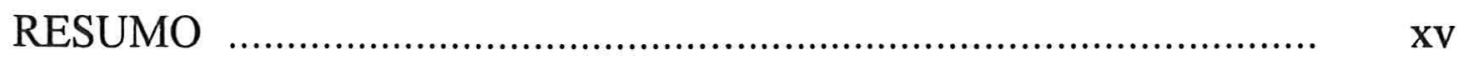

SUMMARY

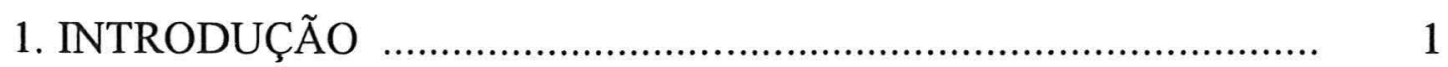

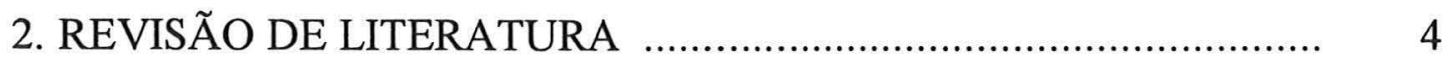

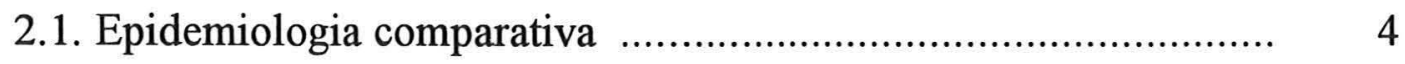

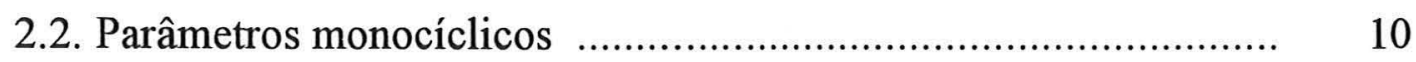

2.3. Quantificação da doença no campo .................................. 12

2.4. A cultura do trigo ....................................................... 15

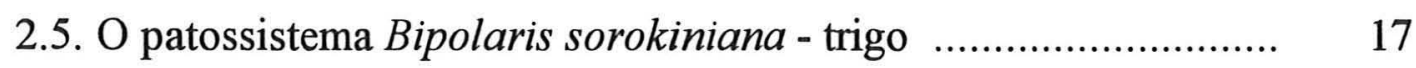

2.5.1. Etiologia e ciclo da doença .................................. 17

2.5.2. Influência do ambiente nos parâmetros monocíclicos ...... 20

2.5.3. Dinâmica da epidemia no campo ............................. 22

2.6. O patossistema Puccinia recondita - trigo .............................. 24

2.6.1. Etiologia e ciclo da doença ....................................... 24

2.6.2. Influência do ambiente nos parâmetros monocíclicos ...... 27

2.6.3. Dinâmica da epidemia no campo ............................... 29

2.7. Modelos de simulação .................................................... 32

3. MATERIAL E MÉTODOS ..................................................... 34

3.1. Determinação da área foliar de plantas de trigo ..................... 34

3.2. Experimentos em condições de ambiente controlado ................. 35

3.2.1. Avaliação do efeito da temperatura nos parâmetros monocíclicos da helmintosporiose 
3.2.1.1. Material vegetal ............................................ $\quad 35$

3.2.1.2. Obtenção e produção do inóculo ....................... 35

3.2.1.3. Inoculação ………………………………..... 36

3.2.1.4. Quantificação de parâmetros monocíclicos ...... 37

3.2.2. Avaliação do efeito da temperatura nos parâmetros monocíclicos da ferrugem da folha ............................... 39

3.2.2.1. Material vegetal ............................................. $\quad 39$

3.2.2.2. Obtenção e produção do inóculo ...................... 39

3.2.2.3. Inoculação .................................................... 40

3.2.2.4. Quantificação de parâmetros monocíclicos ...... 40

3.2.3. Avaliação do efeito da temperatura e do período de molhamento nos parâmetros monocíclicos da helmintosporiose ...................................................... 42

3.2.3.1. Material vegetal ........................................... 42

3.2.3.2. Obtenção e produção do inóculo ...................... 42

3.2.3.3. Inoculação ................................................... 43

3.2.3.4. Quantificação de parâmetros monocíclicos ...... 43

3.3. Experimentos em condições de campo ……………………..... 46

3.3.1. Experimento de Ponta Grossa - PR de 1994 .................... $\quad 46$

3.3.2. Experimento de Ponta Grossa - PR de 1995 .................... $\quad 50$

3.4. Estudos de simulação ................................................................ 52

4. RESULTADOS E DISCUSSÃO …................................................ 54

4.1. Experimentos em condições de ambiente controlado .................. 54

4.1.1. Efeito da temperatura nos parâmetros monocíclicos da helmintosporiose e da ferrugem da folha ....................... 54

4.1.2. Efeito da temperatura e do período de molhamento nos parâmetros monocíclicos da helmintosporiose ................ 63

4.2. Experimentos em condições de campo ………........................... 72 


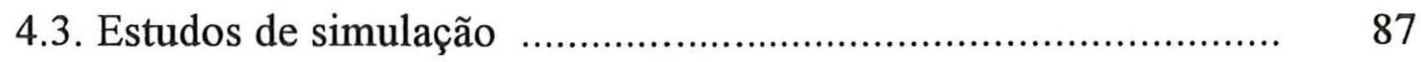

5. CONCLUSÕES ............................................................... 93

REFERÊNCIAS BIBLIOGRÁFICAS …......................................... 94 
Figura $n^{\mathbf{o}}$

Página

01 Escala para avaliação do tamanho das lesões da helmintosporiose do trigo (valores em $\mathrm{mm}^{2}$ )

02 Curvas de progresso dos dados de freqüência de infecção (A, B,), em número de lesões por $\mathrm{cm}^{2}$, e severidade $(\mathrm{C}$, D), em porcentagem, da helmintosporiose $(A, C)$ e da ferrugem da folha (B, D) do trigo, nas temperaturas de 16 , 21 e $26^{\circ} \mathrm{C}$, e 24 horas de câmara úmida. Cada ponto representa a média de cinco repetições

03 Efeito da temperatura $(\mathrm{T})$ e do período de molhamento (M) sobre a freqüência de infecção (FI) da helmintosporiose, em plantas adultas de trigo do cultivar IAC-24. Média de três repetições

04 Efeito da temperatura ( $\mathrm{T}$ ) sobre o período de incubação (PI) da helmintosporiose, em plantas do cultivar de trigo IAC-24 66

05 Efeito da temperatura (T) e do período de molhamento (M) sobre a severidade (SEV) da helmintosporiose, em plantas adultas de trigo do cultivar IAC-24. Média de três repetições 
06 Médias e erros padrão dos dados de número de lesões por $\mathrm{cm}^{2}$ (A, B) e porcentagem de severidade (C, D) da helmintosporiose $(A, C)$ e da ferrugem da folha $(B, D)$, em plantas marcadas do cultivar de trigo IAC-24, no ano de 1994. Cada ponto representa a média de dez plantas por parcela

07 Médias e erros padrão dos dados de número de lesões por $\mathrm{cm}^{2}$ (A, B) e porcentagem de severidade $(\mathrm{C}, \mathrm{D})$ da helmintosporiose $(A, C)$ e da ferrugem da folha $(B, D)$, em plantas marcadas do cultivar de trigo BR-34, no ano de 1994. Cada ponto representa a média de dez plantas por parcela

08 Médias e erros padrão dos dados de número de lesões por $\mathrm{cm}^{2}(\mathrm{~A}, \mathrm{~B})$ e porcentagem de severidade $(\mathrm{C}, \mathrm{D}) \mathrm{da}$ helmintosporiose e da ferrugem da folha, em folhas dos cultivares de trigo IAC-24 (A, C) e BR-34 (B, D), amostradas no ano de 1994. Cada ponto representa a média de cinqüenta a sessenta folhas

09 Médias e erros padrão dos dados de número de lesões por $\mathrm{cm}^{2}$ (A, B) e porcentagem de severidade $(C, D)$ da helmintosporiose $(A, C)$ e da ferrugem da folha $(B, D)$, em plantas marcadas do cultivar de trigo IAC-24, no ano de 1995. Cada ponto representa a média de dez plantas por parcela 
10 Médias e erros padrão dos dados de número de lesões por $\mathrm{cm}^{2}$ (A) e porcentagem de severidade (B) da ferrugem da folha, em plantas marcadas do cultivar de trigo BR-34, no ano de 1995. Cada ponto representa a média de dez plantas por parcela

11 Simulação de curvas de progresso de epidemias de helmintosporiose, com crescimento de lesão, e de ferrugem da folha, sem crescimento de lesão

12 Curvas de progresso de epidemias de helmintosporiose do trigo, obtidas em função do efeito simulado de variações no período latente em dias (A), na taxa diária de crescimento da lesão em $\mathrm{mm}^{2}$ por dia (B), na proporção de sítios suscetíveis (C), na máxima taxa básica de infecção em lesões por lesão por dia (D), na proporção de lesões esporulantes (E), e no tamanho inicial da lesão em $\mathrm{mm}^{2}$ (F)

13 Curvas de progresso de epidemias de ferrugem da folha do trigo, obtidas em função do efeito simulado de variações no período latente em dias (A), na taxa diária de crescimento da lesão em $\mathrm{mm}^{2}$ por dia (B), na proporção de sítios suscetíveis (C), na máxima taxa básica de infecção em lesões por lesão por dia (D), na proporção de lesões esporulantes (E), e no tamanho inicial da lesão em $\mathrm{mm}^{2}$ (F) 


\section{LISTA DE TABELAS}

Tabela $\mathrm{n}^{\mathrm{o}}$

Página

01 Parâmetros iniciais das simulações da helmintosporiose e da ferrugem da folha do trigo, com o programa LESION EXPANSION MODEL (Berger \& Bergamin Filho, 1990)

02 Equações, e respectivos coeficientes de determinação $\left(\mathrm{R}^{2}\right)$, que melhor se ajustaram aos dados de freqüência de infecção (FI), em número de lesões por $\mathrm{cm}^{2}$, e de severidade (SEV), em porcentagem, da helmintosporiose $(\mathrm{H})$ e da ferrugem da folha $(\mathrm{F})$ do trigo, em função da temperatura $(\mathrm{T})$, em graus centígrados, através de regressões não-lineares.

03 Freqüência de infecção, em número de lesões por $\mathrm{cm}^{2}$, da helmintosporiose e da ferrugem da folha do trigo, em plântulas do cultivar IAC-24 (estádios 12 a 14 da escala de Zadoks et al., 1974), incubadas em diferentes temperaturas, sob 24 horas de câmara úmida. Valores estimados pelas regressões não-lineares dos dados (exceto para a helmintosporiose a $26^{\circ} \mathrm{C}$ ). Média de cinco repetições 
04 Período de incubação da helmintosporiose e período latente da ferrugem da folha do trigo, em dias, em plântulas do cultivar IAC-24 (estádios 12 a 14 da escala de Zadoks et al., 1974), incubadas em diferentes temperaturas, sob 24 horas de câmara úmida. Valores estimados pelas regressões não-lineares dos dados (exceto para a helmintosporiose a 21 e $26^{\circ} \mathrm{C}$ ). Média de cinco repetições

05 Severidade, em porcentagem, da helmintosporiose e da ferrugem da folha do trigo, em plântulas do cultivar IAC24 (estádios 12 a 14 da escala de Zadoks et al., 1974), incubadas em diferentes temperaturas, sob 24 horas de câmara úmida. Valores estimados pelas regressões nãolineares dos dados. Média de cinco repetições

06 Área sob as curvas de progresso das doenças (AUDPC) helmintosporiose e ferrugem da folha, em condições naturais de infecção, em plantas de trigo dos cultivares IAC-24 e BR-34, no ano de 1994. Valores obtidos das curvas de progresso das doenças em lesões por $\mathrm{cm}^{2}$. Média de quatro repetições 
07 Área sob as curvas de progresso das doenças (AUDPC) helmintosporiose e ferrugem da folha, em condições naturais de infecção, em plantas de trigo dos cultivares IAC-24 e BR-34, no ano de 1994. Valores obtidos das curvas de progresso das doenças em severidade. Média de quatro repetições

08 Área sob as curvas de progresso das doenças (AUDPC) helmintosporiose e ferrugem da folha, em condições naturais de infecção, em plantas de trigo dos cultivares IAC-24 e BR-34, no ano de 1995. Valores obtidos das curvas de progresso das doenças em lesões por $\mathrm{cm}^{2}$. Média de quatro repetições

09 Área sob as curvas de progresso das doenças (AUDPC) helmintosporiose e ferrugem da folha, em condições naturais de infecção, em plantas de trigo dos cultivares IAC-24 e BR-34, no ano de 1995. Valores obtidos das curvas de progresso das doenças em severidade. Média de quatro repetições 


\section{APÊNDICE}

Apêndice $\mathrm{n}^{\mathrm{o}}$

Página

01 Dados climáticos (temperaturas mínima, média e máxima, umidade relativa do ar média e pluviometria) diários, obtidos no Campo Demonstrativo e Experimental da Cooperativa Agropecuária BATAVO, Ponta Grossa - PR, em 1994

02 Dados climáticos (temperaturas mínima, média e máxima, umidade relativa do ar média e pluviometria) diários, obtidos no Campo Demonstrativo e Experimental da Cooperativa Agropecuária BATAVO, Ponta Grossa - PR, em 1995 


\title{
EPIDEMIOLOGIA COMPARATIVA ENTRE A HELMINTOSPORIOSE E A FERRUGEM DA FOLHA DO TRIGO: ESTUDOS MONOCÍCLICOS, POLICÍCLICOS E DE SIMULAÇÃO
}

\author{
Autora: GISELE ABIGAIL MONTAN TORRES \\ Orientadora: PROF $^{\mathrm{a}} \mathrm{DR}^{\mathrm{a}}$ LILIAN AMORIM
}

\section{RESUMO}

Epidemias tropicais e temperadas possuem estrutura e comportamento distintos. Apesar disso, a epidemiologia tropical foi sempre tratada como uma extensão da temperada.

Doenças típicas de climas temperados têm o aumento do número de lesões como principal característica do progresso de epidemias. Já as doenças de climas tropicais apresentam o crescimento das lesões, além do aumento do número de lesões, para promover o desenvolvimento da doença.

O objetivo deste trabalho foi o de comparar os patossistemas Bipolaris sorokiniana - trigo e Puccinia recondita - trigo, utilizados como modelos de epidemia tropical e temperada, respectivamente, em uma cultura típica de clima temperado. Para ambos os patossistemas foram realizados experimentos em condições controladas de ambiente com o cultivar de trigo IAC24 e em condições de campo, com os cultivares de trigo IAC-24 e BR-34, nos anos de 1994 e 1995, além de estudos de simulação, através de um programa computadorizado de progresso de doenças, com e sem expansão de lesões.

Foram avaliados os parâmetros monocíclicos (freqüência de infecção, período de incubação ou latência e severidade) das duas doenças, em câmaras de crescimento. Num primeiro experimento, foram testadas as temperaturas de 16,21 e $26^{\circ} \mathrm{C}$. A temperatura de $26^{\circ} \mathrm{C}$ mostrou-se como a mais favorável para a helmintosporiose, enquanto que para a ferrugem foi a de $16^{\circ} \mathrm{C}$. Sob temperatura favorável, ambas as doenças apresentaram maior freqüência de infecção, menor período de incubação ou latência e maior severidade. Observouse ainda que a severidade de ferrugem é função do número de pústulas por $\mathrm{cm}^{2} \mathrm{de}$ 
folha, enquanto que a de helmintosporiose, do tamanho de suas lesões, uma vez que esta sempre apresentou menor número de lesões que a ferrugem, e maiores valores de severidade. Foi feito um segundo experimento em condições controladas de ambiente, no qual foi estudado o efeito da temperatura e do período de molhamento nos parâmetros monocíclicos da helmintosporiose. Houve efeito significativo tanto do aumento da temperatura, quanto do aumento da umidade, sobre a freqüência de infecção, o período de incubação e a severidade.

Em condições de campo, nos dois anos estudados, a ferrugem apresentou maior número de lesões por área de tecido foliar do que a helmintosporiose. Quanto à severidade, constatou-se efeito da interação patógenocultivar. Em função do crescimento de suas lesões, B. sorokiniana apresentou maior severidade no cultivar IAC-24. O cultivar BR-34, por sua vez, teve severidade de ferrugem maior que de helmintosporiose, devido ao alto número de pústulas de $P$. recondita por $\mathrm{cm}^{2}$.

Nos estudos de simulação, assim como nos estudos monocíclicos e policíclicos, verifica-se que para a ferrugem, o aparecimento de novas lesões é responsável por $100 \%$ da severidade final da doença, enquanto que para a helmintosporiose, a expansão de lesões contribui com $87 \%$ da quantidade de doença. 


\title{
COMPARATIVE EPIDEMIOLOGY OF SPOT BLOTCH AND LEAF RUST OF WHEAT: MONOCYCLIC, POLICYCLIC AND SIMULATION STUDIES
}

\author{
Author: GISELE ABIGAIL MONTAN TORRES \\ Adviser: PROF. LILIAN AMORIM
}

\section{SUMMARY}

Tropical and temperate epidemics have different structure and behaviour. Nevertheless tropical epidemiology has been treated as an extension of the temperate one.

Typical diseases of temperate climates have the increase of the lesion numbers as the main characteristic of epidemic progress. Tropical climate diseases, however, besides the increase in the number of lesions show the lesion expansion to promote their development.

The objective of this study was to compare the pathosystems Bipolaris sorokiniana - wheat and Puccinia recondita - wheat, used as models of tropical and temperate epidemics, respectively, in a typical temperate crop. Experiments were carried out for both pathosystems under controlled conditions with the wheat cultivar IAC-24 and under field conditions with the wheat cultivars IAC-24 and BR-34, during the years of 1994 and 1995. Simulation studies, through a computer program of disease progress, with and without lesion expansion, were also performed.

Monocyclic parameters (frequency of infection, incubation or latent periods and severity) for both diseases were evaluated in growth chambers. In a first experiment, temperatures of 16,21 and $26^{\circ} \mathrm{C}$ were tested. Temperatures of 26 and $16^{\circ} \mathrm{C}$ were the most favorable for the spot blotch and leaf rust, respectively. Under favorable temperature, both diseases showed higher frequency of infection, lower incubation or latent periods and higher severity. Rust severity was observed to be a function of the number of pustules per $\mathrm{cm}^{2}$ of leaf area, while the spot blotch was dependent of the lesion expansion, since this 
disease always showed smaller lesion number than the rust, as well as higher severity values. In a second experiment, the effect of temperature and leaf wetness period on the monocyclic parameters of spot blotch was also studied under controlled conditions. Temperature and humidity had significant effects on the frequency of infection, incubation period and severity.

Under field conditions, rust showed a higher number of lesions per leaf area than spot blotch. Concerning to disease severity, effect of the pathogencultivar interaction was verified. B. sorokiniana showed higher severity on the cultivar IAC-24, on the basis of the lesion expansion. Cultivar BR-34, on the other hand, had higher severity for rust than for spot blotch, due to the high number of pustules of $P$. recondita per $\mathrm{cm}^{2}$.

In the simulation studies, as well as in the monocyclic and policyclic ones, it was found that for rust the appearance of new lesions is responsible for $100 \%$ of the final disease severity, whereas for spot blotch the lesion expansion contributes with $87 \%$ of the disease amount. 


\section{INTRODUÇÃO}

A epidemiologia é a ciência da doença em populações (Vanderplank, 1963). Em outras palavras, é a ciência de populações de patógenos em populações de hospedeiros e a doença resultante desta interação sob a influência ambiental e a interferência humana (Kranz, 1974). Seus objetivos são a compreensão da estrutura e do comportamento das epidemias (Kranz, 1978) e, subseqüentemente, a elaboração de estratégias de controle (Campbell \& Madden, 1990).

O entendimento tem como base a comparação (Kranz, 1974). A epidemiologia comparativa delineia-se a partir da observação e da descrição de fenômenos que ocorrem no curso de uma epidemia até o desenvolvimento de generalizações (Kranz, 1978). Busca-se, através dela, avaliar o efeito de cada fator isolado e da somatória de fatores sobre a dinâmica da epidemia (Kranz, 1974). Contudo, a observação e a descrição destes fenômenos estiveram sempre voltadas para países da zona temperada (Paddock, 1967). Sabe-se, no entanto, que epidemias temperadas e tropicais possuem estrutura e comportamento diferentes (Bergamin Filho et al., 1986; Bergamin Filho, 1990; Bergamin Filho \& Amorim, 1996). Independentemente destas diferenças, tanto nos países temperados como nos trópicos, são unificadas as medidas de controle de doenças e o direcionamento dos programas de melhoramento visando resistência. 
Estudos apontam diferenças claras quanto ao desenvolvimento de doenças tropicais e temperadas (Bergamin Filho et al., 1986; Bergamin Filho, 1990; Bergamin Filho \& Amorim, 1996), e as mais significativas são apresentadas a seguir.

As regiões tropicais apresentam variações anuais mais estáveis que as temperadas, o que propicia condições para a manutenção de uma alta densidade de inóculo entre estações de cultivo (Wellman, 1962). Por outro lado, pela existência de uma incisão climática desfavorável, seja ela fria ou seca, tanto a sobrevivência como a disseminação do patógeno são comprometidas em regiões temperadas (Rotem \& Palti, 1980).

Ocorrem diferenças quanto aos modelos de produção de esporos entre patógenos temperados e tropicais. A esporulação de patógenos causadores de doenças típicas de clima temperado apresenta um pico no início do período infeccioso, enquanto que a de patógenos de doenças tropicais dá-se de maneira intermitente durante todo o período infeccioso (Bergamin Filho et al., 1986).

A estratégia utilizada para o desenvolvimento de doenças pelos patógenos tropicais difere daquela dos temperados. Para os primeiros, o crescimento da lesão é a chave para o sucesso da epidemia, enquanto que os temperados baseiam-se no aumento do número de lesões para que haja o progresso da doença (Bergamin Filho, 1990).

Mesmo estabelecidas estas diferenças, a epidemiologia tropical é uma extensão da temperada. Desta forma, estudos de epidemiologia comparativa, terão como resultado final o estabelecimento de estratégias de controle mais adaptadas às condições dos trópicos e sub-trópicos.

O objetivo deste trabalho foi a comparação dos patossistemas: Bipolaris sorokiniana - trigo e Puccinia recondita - trigo, utilizados como modelos de epidemia tropical e epidemia temperada, respectivamente, em uma cultura típica de clima temperado. O primeiro patógeno lança mão do aumento do 
tamanho das lesões, além do aumento do número de lesões, para promover o progresso da epidemia, enquanto que o segundo tem o desenvolvimento da doença baseado principalmente no aumento do número de lesões.

Para ambos os patossistemas, foram realizados experimentos em condições controladas de ambiente e em condições de campo. Os primeiros tinham a finalidade de avaliar o efeito da temperatura e da umidade sobre os parâmetros monocíclicos das doenças. Nos experimentos de campo, foram determinadas as curvas de progresso das doenças em condições naturais de infecção, quantificadas tanto pelo número de lesões por $\mathrm{cm}^{2}$, quanto pela área foliar atacada.

Por fim, com base nos dados obtidos, foi comparado o efeito de diferentes parâmetros epidemiológicos no desenvolvimento de epidemias tropicais e temperadas, através de um programa computadorizado de simulação de progresso de doenças, com e sem expansão de lesões, desenvolvido por Berger \& Bergamin Filho (1990). 


\section{REVISÃO BIBLIOGRÁFICA}

\subsection{Epidemiologia comparativa}

A comparação é a principal ferramenta no estudo de sistemas. Sistema é uma secção limitada do mundo real. A análise de sistemas visa o seu entendimento e a sua descrição quantitativa (Zadoks, 1971). Através da comparação, o fitopatologista testa a validade de teorias e estabelece princípios (Kranz, 1988). A epidemiologia comparativa serve à definição de similaridades $\mathrm{e}$ diferenças entre os sistemas, caracterizando-os como semelhantes ou não. Além da estrutura do sistema, constituída pelos elementos que o compõem, visa-se o conhecimento do comportamento deste sistema. Este padrão comportamental é resultado da interação entre os diferentes elementos (Kranz, 1978; Kranz, 1980).

A fitopatologia como ciência teve sua origem e crescimento em países da zona temperada (Paddock, 1967). Contrariamente ao que se observa nestas regiões, em áreas tropicais há uma gama inumerável de patógenos infectando uma mesma cultura (Moreno, 1985). O sistema tropical foi, ao longo do tempo, pesquisado sob uma visão reducionista (Janzen, 1973) a despeito de sua grande diversidade (Buddenhagen, 1983), devido à experiência prévia na agricultura temperada (Moreno, 1985). Além da diversidade biológica (Grant, 1962; Wellman, 1962), foi ignorada a diversidade ambiental (Buddenhagen, 1983 ) presente nos trópicos e sub-trópicos. Nas áreas temperadas, as condições climáticas são distintas entre as estações do ano, com a presença de uma incisão 
fria no inverno. As regiões tropicais, por sua vez, não possuem esta incisão fria e suas temperaturas caracterizam-se por serem mais estáveis durante 0 ano. Enquanto as regiões temperadas apresentam uniformidade climática ao longo de extensas áreas, nos trópicos, em curtas distâncias revelam-se diferenças climáticas (Wellman, 1962). A falta de estações do ano bem definidas é também fator que interfere na epidemiologia das doenças de plantas nos trópicos (Waller, 1976). Esta ausência de um período desfavorável ao desenvolvimento do patógeno durante o ano determina a presença contínua de inóculo. A endemicidade é, portanto, importante característica do sistema tropical (Waller, 1976; Putter, 1980).

Nas áreas de clima temperado, a variação no comprimento do dia afeta tanto o crescimento das plantas quanto a ocorrência de epidemias. Em áreas tropicais, por outro lado, por causa das altas temperaturas e altos níveis de radiação solar, é a disponibilidade de umidade que assume grande importância para os processos biológicos (Waller, 1976). Em clima temperado, os patógenos apresentam adaptação a uma maior amplitude de temperatura do que em clima tropical. Entretanto, geralmente, eles possuem também maiores requerimentos de umidade para o desenvolvimento de doenças, ao contrário do que ocorre para patógenos adaptados às condições restritas de umidade dos trópicos. Patógenos tropicais, inclusive, chegam a apresentar a versatilidade de se beneficiarem com interrupções do período de molhamento por períodos de seca (Bashi \& Rotem, 1974; Luz, 1982; Duczek \& Wildermuth, 1992; Sache \& Vallavieille-Pope, 1993; Vallavieille-Pope et al., 1995).

As medidas de controle de doenças utilizadas em países tropicais e sub-tropicais são aquelas que obtiveram sucesso nos países temperados (Paddock, 1967). Porém, sabe-se que as doenças são mais numerosas nos trópicos (Calpouzos, 1962; Sequeira, 1962; Waller, 1976). Além do que, alterado o 
equilíbrio de um ecossistema tropical, mais dificilmente ele é restaurado (Moreno, 1985).

Comparando-se a produção de esporos de vários patógenos, distingue-se dois padrões de comportamento. No primeiro deles, observa-se um pico de esporulação no início do período infeccioso. No segundo, a esporulação apresenta vários picos ao longo de todo o período infeccioso. Constata-se, então, que o primeiro grupo de patógenos é formado principalmente de fungos causadores de doenças importantes para as condições temperadas e no outro, de patógenos típicos de climas quentes (Castro et al., 1984; Fegies, 1985; Bergamin Filho et al., 1986; Mendes \& Bergamin Filho, 1989; Mendes \& Bergamin Filho, 1990).

Do ponto de vista da utilização da resistência como medida de controle, em virtude da facilidade da genética Mendeliana, os fitopatologistas deram, ao longo do tempo, preferência à resistência vertical. Tal prática passou a ser questionada tendo em vista os perigos da uniformidade genética e da vasta monocultura. Inclusive observou-se que, historicamente, as epidemias ocorreram, em parte, devido ao uso extensivo de variedades com o mesmo germoplasma. Buscando-se um novo direcionamento para os programas de melhoramento, sugeriu-se a utilização de multilinhas como medida de controle de doenças (Browning \& Frey, 1969). As multilinhas consistem da mistura de cultivares com diferentes genes de resistência vertical, os quais, em conjunto, fornecem um efeito semelhante ao de uma linhagem pura com resistência horizontal. Esta diversidade genética garante a redução tanto do inóculo inicial quanto das taxas de desenvolvimento das doenças. Acreditava-se que a doença teria um desenvolvimento mais lento numa mistura de linhagens ou cultivares com diferentes genes de resistência. Este efeito é verificado principalmente no caso de ferrugens de cereais (Browning \& Frey, 1969; Leonard, 1969; Johnson \& Taylor, 1976; Luthra \& Rao, 1979; Buddenhagen, 1983). 
As ferrugens, doenças típicas de climas temperados, apresentam o aumento do número de lesões como principal característica do progresso de epidemias. Shaner \& Hess (1978) ressaltam a importância da produção de novas lesões quando descrevem a epidemia de ferrugem da folha do trigo como sendo o aumento na população de urédias.

James \& Shih (1973), comparando o desenvolvimento do oídio e da ferrugem da folha em trigo constataram que a ferrugem aumenta relativamente mais pela incidência que pela severidade. Isto ocorre provavelmente devido ao maior número e mobilidade de seus esporos, os quais darão origem a novas lesões em folhas não infectadas. Imhoff et al. (1982b), estudando a ferrugem do feijoeiro, verificaram que o tempo e a quantidade de esporulação do patógeno também estão entre os mais importantes fatores na determinação das taxas de aumento da doença. A esporulação, porém, é de difícil quantificação precisa in vivo (Johnson \& Taylor, 1976). Adota-se, então, o período latente como sendo o ideal na avaliação da resistência, pelo fato de ser um parâmetro de tempo diretamente relacionado com a esporulação do patógeno (Zadoks, 1971; Parlevliet \& Van Ommeren, 1975; Parlevliet, 1979; Parlevliet, 1986).

Em trabalho recente, Lannou et al. (1994a) analisaram o efeito do crescimento da lesão na eficiência de misturas de cultivares para o controle de doenças, através de epidemias simuladas em computador. Foram estudadas diferentes taxas de multiplicação do patógeno e diferentes gradientes de dispersão de esporos. Ambos os fatores, assim como a disponibilidade de tecido hospedeiro interferem sobre a taxa de crescimento da lesão, a qual tem efeito inversamente proporcional à eficácia das misturas de cultivares para o controle de doenças. Neste ponto, reside outra diferença, talvez a mais importante, entre patossistemas temperados e tropicais. Enquanto doenças típicas de condições temperadas, como dito anteriormente, crescem principalmente devido ao aumento do número de 
lesões, doenças de climas tropicais e sub-tropicais apresentam, além do aumento no número de lesões, o aumento do tamanho das lesões.

Berger (1973) observou que em condições de campo, o aumento da severidade da helmintosporiose do milho é explicado pelo aumento no tamanho das lesões. Houve um aumento da doença, mesmo com a diminuição do número de lesões, conseqüência da coalescência das lesões já existentes. O mesmo comportamento foi verificado em Puccinia striiformis, que diferentemente das demais ferrugens de cereais, apresenta crescimento de lesão (Emge et al., 1975). Para as septorioses do trigo, foram observadas taxas de crescimento da lesão de até 3,53 $\mathrm{mm}^{2}$ por dia (Shaner \& Buechley, 1995).

Em função desta característica, epidemias tropicais são menos dependentes do clima, comparativamente às epidemias temperadas (Zadoks, 1984; Bergamin Filho, 1990). O crescimento da lesão determina o aumento da severidade, sem a ocorrência de novas infecções (Emge et al., 1975; Mehta, 1981b; Xie, $1989^{1}$ citado por Shaner \& Buechley, 1995). Mas, se um extenso período de umidade ocorrer depois de uma infecção recente, novas infecções poderão também ocorrer contribuindo para o aumento da quantidade de doença (Shaner \& Buechley, 1995).

O trabalho de Fegies (1985) confirma a menor importância relativa do aumento do número de lesões para doenças tipicamente tropicais. Em estudos de simulação, observou-se que para o padrão de produção de esporos destas doenças, a variação do período infeccioso não altera a velocidade de desenvolvimento da epidemia. O crescimento da lesão exerceria, então, maior influência sobre o progresso da epidemia.

\footnotetext{
${ }^{1}$ XIE, B. Effects of cultivar and inoculation conditions on Septoria nodorum blotch development on wheat. West Lafayette, 1989. M.S. Thesis - Purdue University.
} 
Para Bipolaris sorokiniana, o período máximo de esporulação, em folhas bandeira de trigo, foi de 30 dias e a produção máxima foi de 487 conídios ' por lesão por dia. Puccinia recondita, por sua vez, apresentou um período infeccioso de 60 a 72 dias, e a produção de esporos foi de 767 esporos por pústula por dia, aproximadamente (Mehta \& Zadoks, 1970; Mehta, 1981b). Comparativamente, o primeiro deles tem produção de esporos bem menor. Porém, ele pode ser mais desastroso, devido ao fato de apresentar crescimento da lesão, inclusive no trabalho de Mehta (1981b), verificou-se que uma única lesão foi capaz de cobrir área correspondente a $22,7 \%$ da área foliar.

Outros trabalhos chegam a sugerir a adoção do crescimento da lesão como parâmetro na avaliação da resistência de plantas a determinadas doenças, e que ele deve ser levado em consideração na análise do desenvolvimento de epidemias. No caso, epidemias de doenças tipicamente tropicais que apresentam a distinta característica de aumento do tamanho de suas lesões (Emge et al., 1975; Mehta, 1981b; Berger \& Jones, 1985; Vitti, 1993; Sache \& Vallavieille-Pope, 1993).

Com base no exposto, questiona-se o emprego das mesmas medidas de controle para doenças tropicais e temperadas. Sequeira (1962) cita o trabalho de Ward $(1882)^{2}$ que foi um dos primeiros a estabelecer o conceito básico do controle preventivo de fungos parasíticos. Com essa maior independência dos patógenos tropicais em relação ao clima, aliado ao caráter endêmico das doenças por eles causadas, sanitização passa a ser a palavra-chave para o seu controle. As práticas de sanitização visam a redução do inóculo inicial a um nível suficientemente baixo para que o desenvolvimento normal da doença não atinja nível alto para causar danos apreciáveis à cultura (Berger, 1977). Esta redução do inóculo inicial seria a base das medidas de controle de doenças

\footnotetext{
${ }^{2}$ WARD, H.M. Researches on the life history of Hemileia vastatrix. J. Linn. Soc., v.19, p. 299-335, 1882.
} 
tropicais, uma vez verificada e quantificada a maior influência do crescimento das lesões sobre o desenvolvimento de epidemias (Bergamin Filho \& Amorim, 1996).

\subsection{Parâmetros monocíclicos}

Para o entendimento de fenômenos em nível de população, normalmente utiliza-se estudos em nível de indivíduo. De modo geral, estes estudos analisam processos monocíclicos (Zadoks \& Schein, 1980), os quais englobam eventos de um único ciclo de vida do patógeno.

$\mathrm{Na}$ análise de processos monocíclicos, são utilizados experimentos em condições controladas de ambiente. Eles têm a função de complementar estudos desenvolvidos em nível de campo. No campo, há diversos fatores em mudança constante e simultânea. Simular todas estas alterações é impossível, porém pode-se avaliar o efeito de cada fator isoladamente, devendo-se para isso estabelecer uma hierarquia dos elementos constituintes da epidemia (Kranz, 1978). Os experimentos em condições controladas indicam o que pode, mas não necessariamente o que deve ocorrer no campo.

Os parâmetros monocíclicos mais utilizados em epidemiologia são: período de incubação, período latente, freqüência de infecção e esporulação. Parlevliet (1979) define da seguinte maneira estes parâmetros:

- período de incubação é o período de tempo entre a inoculação e o aparecimento de sintomas;

- período latente é o período de tempo entre a inoculação e a produção de lesões esporulantes;

- $\quad$ freqüência de infecção é o número de lesões produzidas por unidade de área, a partir de uma concentração conhecida de esporos; e, 
- $\quad$ esporulação é o número de esporos produzidos por unidade de área de tecido infectado e/ou por unidade de tempo.

Entre os mais importantes fatores ambientais que exercem influência sobre a incidência e o desenvolvimento das doenças estão a temperatura e a umidade. Rotem (1988) afirma que somente os experimentos em condições controladas fornecem dados dos requerimentos de temperatura e umidade em fases específicas do ciclo de vida do patógeno. À medida que as condições de temperatura e umidade são favoráveis ao desenvolvimento da doença, menores são o período de incubação e o período latente, e maiores são a freqüência de infecção e a esporulação. Certamente, estas condições variam entre os diferentes patossistemas (Heagle \& Moore, 1970; Castor et al., 1977; Butler \& Jadhav, 1991; Carisse et al., 1993; Habtu \& Zadoks, 1995).

Temperatura e umidade podem interagir entre si afetando os parâmetros monocíclicos. Politowski \& Browning (1975) verificaram que o período mínimo de molhamento requerido por Puccinia coronata avenae para a formação de pústulas em aveia variou de acordo com a temperatura.

Outros fatores podem também influenciar estes parâmetros. Entre os fatores que afetaram a freqüência de infecção e a esporulação de Uromyces appendiculatus em feijão está a intensidade de infecção. Quanto maior era a densidade de pústulas, menor era a freqüência de infecção e a taxa de produção de esporos do fungo (Yarwood, 1961).

Mendes \& Bergamin Filho (1989) observaram que folhas mais velhas de feijão são mais resistentes ao desenvolvimento da ferrugem, independentemente do tipo de folha e da linhagem de feijoeiro. Quanto mais velha a folha, maiores foram o período de incubação e o período latente, e menor, a freqüência de infecção. Os mesmos autores, em outro trabalho, constataram que a esporulação de Uromyces appendiculatus é mais elevada em folhas trifoliadas e na face inferior das folhas (Mendes \& Bergamin Filho, 1990). 
Parlevliet (1975) observou que o período latente da ferrugem da cevada sofreu influência da posição da folha na planta, da idade da folha, e da idade da planta. Distinguiu-se dois comportamentos deste parâmetro: o seu aumento com o desenvolvimento da planta e o seu decréscimo com a idade da folha. O valor do período latente no estádio de plântula não foi representativo do que ocorreu no estádio de planta adulta, especialmente no tocante aos cultivares

mais resistentes. Posteriormente, o mesmo autor verificou que à medida que a freqüência de infeç̧ão era menor, havia linearmente um aumento no período latente (Parlevliet, 1986).

Para Erwinia carotovora subsp. carotovora em tomate, à medida que a concentração do inóculo, a suscetibilidade do cultivar, e a maturidade eram maiores, menor era o período latente, maior era a freqüência de infeç̧ão e maior, a taxa de desenvolvimento da doença (Berger \& Bartz, 1982).

A forma de parasitismo é outro fator que influencia a esporulação de fungos. Cohen \& Rotem (1970) verificaram que inibindo a fotossíntese da planta hospedeira, é diminuída a esporulação de parasitas obrigatórios, mas este efeito é menos pronunciado no caso de parasitas necrotróficos. Ainda, há exemplos de outros autores que, trabalhando com parasitas necrotróficos, afirmam serem estes fungos favorecidos por temperaturas desfavoráveis e, até mesmo, prejudiciais ao desenvolvimento da planta (Clark \& Dickson, 1958; Colhoun, 1973; Shaner, 1981).

\subsection{Quantificação da doença no campo}

Para o estudo da dinâmica da epidemia em seus ambientes naturais é necessária a determinação da quantidade de doença. A quantidade de doença pode ser expressa pela incidência ou pela severidade. A incidência consiste do 
número de plantas ou partes de plantas com sintomas e a severidade é a área ou volume da planta ocupado por sintomas (Campbell \& Madden, 1990).

A quantificação da doença ao longo do tempo, independentemente de ser através da incidência ou da severidade, tem como resultado a curva de progresso da doença. Ela representa uma integração de todos os efeitos de hospedeiro, patógeno e ambiente no desenvolvimento da epidemia, e promove a oportunidade para a análise, a comparação e o entendimento (Campbell \& Madden, 1990).

A partir das curvas de progresso da doença podem ser estimadas várias características da epidemia como: a quantidade de inóculo inicial, o tempo para o aparecimento dos primeiros sintomas, a duração da epidemia, a forma da curva com a duração de cada fase, o tempo entre duas epidemias (no caso de culturas perenes), a quantidade máxima de doença, a quantidade final de doença, a área sob a curva de progresso da doença (Kranz, 1974). Os parâmetros que serão utilizados nas comparações de curvas de progresso de doença dependerão do objetivo do trabalho a ser desenvolvido.

Também deve ser definida a unidade experimental, com base na doença estudada. Ela pode ser uma planta, ou uma parte de planta, seja um perfilho, uma folha ou um colmo (Teng, 1983). Os intervalos de tempo nos quais serão feitas as avaliações variam de acordo com a doença e com as condições disponíveis de trabalho.

Vários são os fatores que interferem na curva de progresso da doença, como por exemplo, o nível de resistência do hospedeiro, o estádio fenológico da cultura, a temperatura, o período de molhamento, a quantidade de inóculo inicial.

Shaner (1973), ao estudar o oídio do trigo, verificou que cultivares com diferentes níveis de resistência apresentam parâmetros epidemiológicos estatisticamente distintos. Parâmetros estes como taxa de progresso da doença, 
número de lesões por $\mathrm{cm}^{2}$, tamanho da lesão, capacidade de esporulação e período latente. Estas diferenças não havia sido constatadas em experimentos anteriores em casa-de-vegetação.

Enfocando o patossistema Puccinia recondita - trigo, Mehta \& Igarashi (1979) afirmam que a determinação das curvas de progresso de doença em condições naturais de campo constitui o método mais simples e mais barato para a detecção de altos níveis de resistência parcial.

Luke \& Berger (1982) observaram que a ferrugem da cevada apresentou o desenvolvimento de sintomas mais cedo e mais rapidamente em cultivares suscetíveis que em cultivares resistentes. Em todas as avaliações, a severidade da doença foi maior em cultivares suscetíveis. Para a avaliação das taxas de progresso da doença, foram utilizadas as transformações logística e de Gompertz. Na primeira delas, as taxas de cultivares suscetíveis e resistentes não diferiram estatisticamente entre si. Já diferenças significativas puderam ser detectadas, em todos os casos analisados, quando a transformação de Gompertz foi usada.

Os valores da severidade da ferrugem comum do milho diferiram quando foram considerados os estádios fenológicos da planta, os híbridos de milho e a interação destes dois fatores. A severidade era tanto menor quanto maior era a idade da planta. Foi possível a deteç̧ão da resistência de planta adulta para todos os cultivares testados, porém as taxas na qual os híbridos tornavam-se resistentes foram diferentes (Headrick \& Pataky, 1987).

Welty \& Barker (1992), ao estudarem o patossistema Puccinia graminis graminicola - Lolium perenne, constataram que foi possível a distinção dos cultivares pelos seus diferentes níveis de resistência. Foram realizados experimentos em condições controladas de ambiente e em condições de campo. Em ambas as situações, os resultados foram semelhantes. Foram considerados 
dados de incidência e de severidade, além da área sob a curva de progresso da doença - AUDPC.

Imhoff et al. (1982a), em ensaios com a ferrugem do feijoeiro em câmaras de crescimento e em campo, ressaltam além da influência decisiva da temperatura e do molhamento no desenvolvimento da doença, a importância do nível de inóculo inicial. Em campo, as curvas de progresso da doença puderam ser melhor explicadas pela freqüência de molhamento que pela temperatura. Os períodos reduzidos de molhamento contribuem também para a perda da viabilidade do inóculo. Ao se tentar estabelecer uma correlação entre a incidência e a severidade da doença, verificou-se que a variabilidade encontrada em nível de campo foi maior e dependente da estação de cultivo. Os autores afirmam ainda que o progresso de uma epidemia sob condições de temperatura constante é bastante diferente do observado em condições de temperatura variável, mesmo que a temperatura média para as duas epidemias seja similar.

No caso das septorioses do trigo, o clima e o inóculo inicial exerceram papel decisivo na evolução da quantidade de doença, ao longo de vários anos de estudo. As doenças foram avaliadas através dos valores de severidade, das AUDPC e das taxas de progresso das epidemias (Shaner \& Buechley, 1995).

\subsection{A cultura do trigo}

Triticum aestivum é uma gramínea anual, hermafrodita, autógama e ereta. O ciclo do trigo pode ser dividido em fases de desenvolvimento vegetativo, de reprodução, de frutificação e de maturação. A escala fenológica mais conhecida é a de Feekes, melhorada por Large (1954), com onze subdivisões. Zadoks et al. (1974) propuseram nova modificação na escala de 
Feekes, com codificação decimal para os estádios de desenvolvimento, utilizandose dois dígitos. $\mathrm{Na}$ escala proposta, os estádios de desenvolvimento são bem detalhados, servindo a estudos epidemiológicos, aplicação de herbicidas, de fungicidas e avaliação de danos. Em 1979, a escala de desenvolvimento foi mais uma vez modificada, desta vez por Tottman \& Makepeace, sendo atualmente bastante usada (Mehta, 1993).

Os fatores ambientais influenciam os componentes de produção através de seus efeitos sobre o crescimento e o desenvolvimento da cultura, e sobre a produção de matéria seca (Gallagher et al., 1976). Com o objetivo de se conhecer a produção de fotossintetizados para o crescimento do grão, verificou-se que a contribuição da folha bandeira, da primeira e da segunda folha abaixo da folha bandeira foram, respectivamente, de 82,68 e 56\% (Thorne, 1982). Como conseqüência deste fato, em experimentos epidemiológicos, o procedimento mais comum é o de avaliação da folha bandeira ou da média das três folhas superiores das plantas (Teng, 1983; Nutter Jr. et al., 1985).

Condições climáticas desfavoráveis e doenças estão entre os principais fatores adversos ao desenvolvimento da cultura do trigo (Barros, 1985). Portanto, faz-se necessário o conhecimento do sistema de produção, da tecnologia disponível, e do ambiente, possibilitando o controle de doenças. As medidas de controle serão eficientes, uma vez que sejam compatíveis com as particularidades de cada situação. O monitoramento da cultura permite a avaliação direta das situações de risco para a ocorrência de doenças, visto que o limiar de dano econômico é função também do nível de produção.

No ano de 1976, as doenças na cultura do trigo, no Estado do Paraná, provocaram de 40 a $62 \%$ de diminuição na produção, além da depreciação da qualidade do grão (Mehta et al., 1979). Experimentos de campo conduzidos no Rio Grande do Sul, visando a quantificação de danos por doenças foliares, apontam a helmintosporiose e a ferrugem da folha como causas das 
maiores perdas para a cultura do trigo (Luz, 1984). Na América Latina, a situação é similar (Hetzler et al., 1991³, citado por Mehta et al., 1992).

De uma maneira geral, indica-se para o controle de doenças da cultura do trigo, a utilização de resistência varietal, o controle químico, a eliminação dos restos de cultura e de plantas voluntárias, e a rotação de culturas. A eficiência relativa de cada uma destas medidas é função, principalmente, de características da interação patógeno-hospedeiro.

A busca do entendimento da estrutura e do comportamento de diferentes patossistemas, neste caso, diferentes patógenos infectando uma mesma cultura, justifica a epidemiologia comparativa.

\subsection{O patossistema Bipolaris sorokiniana - trigo}

\subsubsection{Etiologia e ciclo da doença}

O agente causal desta doença é o fungo Cochliobolus sativus (Ito \& Kuribayashi) Drechs. ex Dastur (syn.: Bipolaris sorokiniana (Sacc.) Shoemaker, Helminthosporium sativum Pammel, C. M. King \& Bakke). Tradicionalmente, a doença é conhecida como helmintosporiose, em associação à forma imperfeita do fungo. A forma sexuada não é comum na natureza e, antigamente, era difícil de ser obtida em condições de laboratório (Shoemaker, 1955).

No trabalho de Wood (1962) fica evidenciada a existência de raças de Bipolaris sorokiniana. Comprovou-se diferenças quanto à patogenicidade dos

\footnotetext{
${ }^{3}$ HETZleR, J.; EYAL, Z.; MEHTA, Y.R.; CAMPOS, L.A.C.; FEHRMANN, H.; KUSHNIR, U.; OREN, J.Z.; COHEN, L. Interaction between Cochliobolus sativus and wheat cultivars. In: INTERNATIONAL CONFERENCE ON WHEAT FOR NON-TRADITIONAL WARMER AREAS, Mexico, 1991. Proceedings. CIMMYT, 1991. p. 146-64.
} 
isolados, quando estes foram inoculados em trigo, cevada e aveia. Mehta (1981a), em levantamento feito no Brasil, identificou trinta e duas raças diferentes do fungo. Foram detectadas vinte e três raças no Paraná, quatro em São Paulo, três no Rio Grande do Sul, uma no Mato Grosso e uma no Distrito Federal.

Como patógeno de raízes, a doença por ele causada é considerada importante em várias partes do mundo. Entretanto, a infecção pode ocorrer em qualquer estádio de desenvolvimento, onde as várias fases da doença recebe diferentes denominações, de acordo com a parte da planta atacada (Clark \& Dickson, 1958).

Para a mancha foliar, as condições de temperatura ideais ao desenvolvimento são 24 a $28^{\circ} \mathrm{C}$ (Mehta, 1978; Picinini \& Prestes, 1985). A doença assume importância em áreas produtoras de trigo na Ásia, África e América do Sul, que caracterizam-se por clima quente e úmido (Fetch Jr. \& Steffenson, 1994; Villareal et al., 1995). Ela é largamente distribuída no Brasil (Picinini \& Prestes, 1985). No sul de São Paulo, a variedade de trigo IAC-5 apresentou danos de 20 a 50\%, respectivamente, em anos considerados normais e chuvosos, devido à ocorrência da helmintosporiose (Barros, 1985). Em experimentos de campo com cevada, Nutter Jr. et al. (1985) verificaram que a severidade nas três folhas superiores da planta mostrou-se correlacionada com a redução no peso e no rendimento em grãos.

Em experimento de avaliação de variedades de trigo no México, Villareal et al. (1995) verificaram que todos os componentes de produção foram severamente reduzidos pela helmintosporiose. Dentre eles, o mais afetado foi a produção de grãos por $\mathrm{m}^{2}$, seguida pelo peso de mil grãos, grãos por espiga e espigas por $\mathrm{m}^{2}$.

Os sintomas nas folhas caracterizam-se por manchas arredondadas a oblongas, de tamanho variável, de coloração castanho-escura a negra (Mehta, 1978; Cardoso \& Kimati, 1980). As lesões são grandes e o tecido foliar ainda não 
invadido precisa morrer antes que o fungo possa produzir conídios. A infecção secundária é mais complicada, uma vez que o fungo não produz conídios em abundância durante a estação de cultivo (Shaner, 1981). Observa-se, porém, que a esporulação é proporcional à área de tecido foliar necrosado (Stevenson, 19814, citado por Reis et al., 1987).

O desenvolvimento da doença depende da quantidade de inóculo local, pois não há dispersão de esporos a distâncias muito longas (Shaner, 1981). O patógeno desenvolve-se saprofiticamente em restos de cultura e é disseminado tanto pelo vento quanto pela água (Reis \& Wünsche, 1984). Sementes contaminadas e restos culturais infectados estão entre as principais fontes de inóculo primário (Reis, 1988).

$\mathrm{Na}$ semente, o fungo sobrevive também na forma de micélio dormente. Quando o armazenamento das sementes é feito em condições ambientais, situação comum para pequenos agricultores, ocorre uma redução no inóculo. Em conseqüência disso, a germinação das sementes não é afetada na época da semeadura, mesmo com altos níveis iniciais de infecção (Vechiato et al., 1987).

Duczek (1994), em trabalho recente, constatou a presença de dormência constitutiva em conídios de $B$. sorokiniana. A secagem dos esporos induz à dormência proporcionalmente à população existente. Esta dormência pode ser revertida pelo resfriamento ou incubação em solo úmido. O autor sustenta que, uma vez ocorrendo em condições de campo, a dormência funciona como mecanismo que permite ao fungo sobreviver a condições de seca.

A produção de conídios por $B$. sorokiniana apresenta periodicidade diurna, normalmente relacionada a condições secas e de vento, importantes para a sua disseminação (Shaner, 1981). Este tipo de esporo é a

\footnotetext{
${ }^{4}$ STEVENSON, I.L. Timing and nature of seed infection of barley by Cochliobolus sativus. Canadian Journal of Plant Pathology, v.3, n.2, p. 76-85, 1981.
} 
principal estrutura de infecção e de sobrevivência do patógeno, podendo sobreviver no solo por períodos superiores a dois anos (Reis \& Wünsche, 1984).

\subsubsection{Influência do ambiente nos parâmetros monocíclicos}

Clark \& Dickson (1958), testando o efeito da temperatura no desenvolvimento da helmintosporiose, verificaram que o comportamento da doença nas folhas foi diferente daquele verificado nas raízes e em plântulas. Os sintomas de mancha foliar se desenvolveram mais intensamente sob $28^{\circ} \mathrm{C}$. A velocidade de aparecimento dos sintomas apresentou-se da seguinte maneira, nas diferentes temperaturas: $28^{\circ} \mathrm{C}>24^{\circ} \mathrm{C}>20^{\circ} \mathrm{C}>16^{\circ} \mathrm{C}$. De uma maneira geral, o patógeno é favorecido por temperaturas mais elevadas ou naquelas desfavoráveis para o crescimento do hospedeiro.

Wood (1962) confirma as observações do trabalho anterior. O autor analisou o efeito da doença sobre o desenvolvimento de plântulas de trigo, cevada e aveia. Foram constatados diferentes níveis de virulência entre os isolados do fungo. Os sintomas foram mais severos em temperaturas de 20 a $28^{\circ} \mathrm{C}$ no solo. Tal fato foi relacionado ao menor crescimento do hospedeiro sob estas condições.

Morton (1962) avaliou a importância da concentração de esporos, da temperatura e do período de umidade na incubação para o desenvolvimento da helmintosporiose em folhas destacadas de cevada. $\mathrm{O}$ autor constatou que com a concentração de esporos de $1,5 \times 10^{5}$ por ml e temperatura de $30^{\circ} \mathrm{C}$ houve o desenvolvimento de sintomas mais rápido e mais severo, comparativamente com a concentração de $1,5 \times 10^{4}$ conídios por ml e temperaturas de 25 e $20^{\circ} \mathrm{C}$. Observou-se, ainda, que sob $15^{\circ} \mathrm{C}$ não houve o desenvolvimento de sintomas, mesmo em condições de alta umidade. 
$\mathrm{Na}$ busca de fontes de resistência parcial à helmintosporiose, Mehta (1981b) detectou parâmetros diferentes daqueles normalmente adotados na seleção de cultivares. Foram estudados: a produção de conídios, o período infeccioso e a taxa de crescimento da lesão de B. sorokiniana em folhas bandeira de trigo. A esporulação iniciou-se aos 16 dias após a inoculação, com exceção do cultivar Sel. Londrina, cuja esporulação iniciou somente depois de 38 dias da inoculação. O período máximo de esporulação foi de 30 dias e a produção máxima de conídios foi de 487 esporos por lesão por dia. Não foi observada correlação entre o período infeccioso e o número total de conídios produzidos. A baixa taxa de extensão das lesões e o pequeno tamanho final da lesão foram considerados parâmetros desejáveis da resistência parcial à helmintosporiose. Houve correlação entre o tamanho final e a taxa de crescimento da lesão. Mas, não foi observada correlação entre o total de conídios produzidos e o tamanho final da lesão.

Com o objetivo de estudar o efeito da presença de água livre nas folhas, na reação de diferentes cultivares à mancha foliar, plantas de trigo foram submetidas à câmara úmida com atmosfera saturada e fotoperíodo de 12 horas com luz artificial, sob $24^{\circ} \mathrm{C}$, com oscilação de $1^{\circ} \mathrm{C}$. A superfície foliar foi mantida umedecida por períodos de $6,12,18,24,30,36,42,48$ e 54 horas. Observou-se um aumento da severidade com o aumento da umidade pós-inoculação (UPI). O mínimo período de UPI requerido para infeç̧ão foi de 6 horas, mas é possível que com períodos menores pudesse ainda ocorrer infeç̧ão. Este fato explicaria a alta intensidade da doença em regiões com curtos períodos de umidade, durante o cultivo do trigo (Luz, 1982).

Luz \& Bergstrom (1986) analisaram o efeito da temperatura sobre o desenvolvimento da mancha marrom de cultivares de trigo com diferentes níveis de resistência. Após a inoculação, as plantas foram incubadas sob 24 horas de câmara úmida nas temperaturas de $12,18,20,24$ e $28^{\circ} \mathrm{C}$. Para os três cultivares 
testados, houve o aumento do número de lesões por $\mathrm{cm}^{2}$ e da porcentagem de severidade, com o aumento da temperatura. A faixa de temperatura ótima para o desenvolvimento da doença mostrou-se dependente da interação cultivar-isolado. Para cultivares suscetíveis, a faixa ótima foi de 20 a $28^{\circ} \mathrm{C}$, e para cultivares moderadamente resistentes e resistentes, $28^{\circ} \mathrm{C}$. O período de incubação foi menor sob as maiores temperaturas. O período de incubação de 30 horas, estimado sob as temperaturas de 20,24 e $28^{\circ} \mathrm{C}$, diferiu significativamente daquele estimado sob 12 e $18^{\circ} \mathrm{C}$. E, sob estas temperaturas, as estimativas do período de incubação também diferiram entre si.

\subsubsection{Dinâmica da epidemia no campo}

Restos das culturas de inverno, suscetíveis a B. sorokiniana, contribuem para o incremento do inóculo no solo (Reis \& Wünsche, 1984). Os valores de densidade do inóculo do fungo foram significativamente maiores nos sistemas de monocultura que nos de rotação. O mesmo comportamento foi observado para o grau de intensidade das podridões radiculares causadas por este fungo. A rotação de culturas por período de três anos determina o incremento da produção, uma vez que reduz tanto a densidade de inóculo do patógeno, quanto a intensidade das doenças por ele ocasionadas (Reis \& Ambrosi, 1987).

O patógeno pode ser disseminado eficientemente pelo vento e pela água. Os esporos produzidos em órgãos aéreos do trigo são depositados no solo, aumentando a densidade de inóculo para o próximo cultivo. Dois meses após a semeadura, constatou-se a esporulação de $C$. sativus na folhagem do trigo. A doença apresentou intensidade moderada, enquanto os tecidos ainda não estavam necrosados. A esporulação do fungo aumentou a partir do momento em que houve 
a necrose das partes infectadas, até a maturidade das plantas (Reis \& Santos, 1987).

Sentelhas et al. (1993) obtiveram a estimativa de níveis futuros de severidade da helmintosporiose e do oídio do trigo, com quatro dias de antecedência, a partir de dados meteorológicos. Na estimativa da taxa de progresso da helmintosporiose, foi utilizado o produto da temperatura média com o total de chuva e/ou irrigação. Para a estimativa da severidade, utilizou-se como variáveis independentes o valor da severidade observada no dia da avaliação juntamente com a temperatura média. Os coeficientes de determinação das duas equações lineares desenvolvidas foram 0,76 e 0,95 , respectivamente.

Para investigar o padrão de esporulação de $B$. sorokiniana ao longo da estação de cultivo, Duczek (1990) instalou experimentos de campo e de casa-de-vegetação no Canadá. Plantas adultas apresentaram dados de esporulação similares e não foi detectada diferença estatística na produção de conídios em trigo, em relação a outros cereais, como cevada e aveia. Houve aumento da esporulação do patógeno com o amadurecimento da cultura. Este fato parece estar correlacionado com o aumento das áreas necrosada e senescente das plantas. Ainda, foram realizadas regressões múltiplas na tentativa de se correlacionar a esporulação do fungo com variáveis climáticas e do hospedeiro. O estádio de desenvolvimento do hospedeiro mostrou-se como a mais importante variável. Além desta, dentre as variáveis climáticas, as mais importantes foram dados cumulativos de temperatura do solo e dos graus-dia acima de $5^{\circ} \mathrm{C}$.

Em países da zona temperada, há a existência de uma incisão fria e/ou seca durante o inverno. Para se estudar o efeito destas condições sobre o comportamento de B. sorokiniana, Duczek \& Wildermuth (1992) avaliaram a esporulação do patógeno sob temperaturas de congelamento e sob ciclos alternados de seca e umidade. Houve a redução na produção de conídios à medida que ocorreu a diminuição da temperatura, e temperaturas de congelamento 
reduziram drasticamente a esporulação. No entanto, não houve diferença estatística entre os tratamentos com diferentes períodos de congelamento. Por outro lado, a produção de esporos mostrou-se significativamente maior quando o patógeno foi submetido a ciclos alternados de umidade e seca, do que quando ele foi mantido sob constante umidade.

\subsection{O patossistema Puccinia recondita - trigo}

\subsubsection{Etiologia e ciclo da doença}

A ferrugem da folha é a doença do trigo mais disseminada em todo o mundo (Wiese, 1987). No Brasil, ela ocorre todos os anos com intensidade variável de acordo com as condições climáticas (Barros, 1985; Goulart \& Paiva, 1992).

Burleigh et al. (1972b) observaram relação linear entre a severidade da ferrugem da folha e a redução da produção de trigo. O cultivar Sonora 63, em 1976, no Paraná, apresentou 42\% de redução na produção devido à ferrugem da folha (Mehta et al., 1979). Em experimento de campo, no Rio Grande do Sul, a ocorrência de ferrugem provocou a redução do número de grãos por espiga, do peso de mil grãos e do peso do hectolitro (Barcellos \& Ignaczak, 1978).

Nos Estados Unidos, em 1980, quando não ocorreu ferrugem, foram observados danos de $10 \%$ em plantações de trigo. Em 1986, quando houve alta incidência da doença, os danos foram de $21,9 \%$, dos quais $2,1 \%$ teve a ferrugem da folha como responsável. A variação nas reduções de produção estimadas pôde ser explicada em $98 \%$ pelas variáveis climáticas diárias (Eversmeyer \& Kramer, 1990b). 
Apesar da denominação recebida, a doença pode ocorrer em todas as partes da planta. Seu agente causal é o fungo Puccinia recondita Rob. ex Desm. f. sp. tritici (syns. P. rubigo-vera (DC.) Wint., P. triticina Eriks.). Ele apresenta um complexo ciclo de vida que envolve hospedeiros alternativos e até cinco tipos de esporos. Pícnios e aécios são raros, ocorrendo primariamente em espécies de Thalictrum (Wiese, 1987).

O patógeno apresenta um grande número de raças fisiológicas. Em função disso, Long \& Kolmer (1989) propuseram um sistema norte-americano de nomenclatura para $P$. recondita $\mathrm{f}$. sp. tritici com base nas combinações de virulência do patógeno sobre uma gama de cultivares diferenciais, cada qual carregando isoladamente um gene de resistência expresso no estádio de plântula. As combinações são designadas por um código de três letras, seguido por um hífen e por uma listagem dos genes inefetivos do hospedeiro.

Levantamento feito em diferentes regiões do Canadá, no ano de 1990, mostrou que há distintas populações de $P$. recondita, naquele país (Kolmer, 1992). Outros levantamentos, nos anos de 1985, 1988, 1990 e 1992, indicaram também uma alta diversidade na população do fungo, fato que é explicado pela coexistência de extensiva produção dos cultivares locais e intensiva produção de cultivares semi-anões suscetíveis, no país (Ezzahiri \& Diouri, 1994).

Os sintomas típicos da doença são pústulas ou urédias circulares a oblongas, que se espalham nas duas faces das folhas e em toda a parte aérea da planta. Estas pústulas apresentam a epiderme rompida, liberando grande quantidade de uredósporos que, transportados pelo vento, constituirão o inóculo secundário da doença. Os télios formam-se principalmente nas bainhas, e são de coloração negra (Mehta, 1978; Cardoso \& Kimati, 1980).

Uredósporos viáveis e micélio dormente são as principais formas de inóculo primário da ferrugem da folha (Eversmeyer \& Kramer, 1990b; Eversmeyer \& Kramer, 1994). A partir da fonte de inóculo, ocorre um decréscimo 
do número de esporos, tanto no sentido vertical quanto no horizontal, independentemente das condições ambientais (Eversmeyer \& Kramer, 1990a).

Ao longo da estação de cultivo, vários uredósporos são transportados pelo vento e depositados sobre a cultura. Entretanto, nem sempre as condições ambientais são favoráveis para que ocorra a imediata germinação e infecção. Dentre os fatores desfavoráveis à sobrevivência dos uredósporos estão a alta incidência de luz e as altas temperaturas (Hwang, 1942).

Com o objetivo de analisar o efeito inibitório da luz sobre a germinabilidade dos uredósporos de $P$. recondita, verificou-se que a luz inibiu a germinação de esporos submetidos à hidratação. Entretanto, não se pode afirmar que os efeitos da luz sejam dependentes simplesmente da umidade dos esporos, uma vez que aqueles hidratados e subseqüentemente secos apresentaram o mesmo comportamento de esporos hidratados (Givan \& Bromfield, 1964b).

Os mesmo autores, em outro trabalho, estudaram o comportamento de esporos de Puccinia graminis f. sp. tritici, onde a luz inibiu a taxa inicial de germinação. Porém, após 6 horas de incubação, o efeito da luz não foi tão pronunciado. A germinação foi mais influenciada pela luz sob a temperatura de $10^{\circ} \mathrm{C}$ que sob $20^{\circ} \mathrm{C}$. Verificou-se, ainda, que o efeito da luz é reversível com a posterior exposição dos esporos ao escuro (Givan \& Bromfield, 1964a).

Em relação à penetração, enquanto a luz favorece os uredósporos de $P$. graminis $\mathrm{f}$. sp. tritici, ela é fator indiferente para $P$. recondita. Os esporos de ferrugem da folha penetraram em estômatos fechados, em condições de escuro, e mostraram-se insensíveis à concentração de $\mathrm{CO}_{2}$ (Yirgou \& Caldwell, 1968).

Em trabalho sobre a viabilidade de esporos de ferrugem da folha e do colmo, Eversmeyer et al. (1984) constataram que o número de esporos coletados está altamente correlacionado com as trajetórias das correntes de ar e com as estimativas de severidade das doenças. Evidencia-se, assim, a importância 
da dispersão e da deposição de esporos, tanto para a ferrugem da folha quanto para a do colmo (Eversmeyer \& Kramer, 1990a).

\subsubsection{Influência do ambiente nos parâmetros monocíclicos}

Entre os fatores ambientais, o que exerce maior influência sobre os parâmetros monocíclicos da ferrugem da folha do trigo é a temperatura. A temperatura exerce influência sobre o patógeno, sobre o hospedeiro e sobre a interação destes (Broers \& Wallenburg, 1989). Kaul \& Shaner (1989) comentam que, provavelmente, o efeito mais pronunciado é sobre a interação patógenohospedeiro. Denissen (1991) comprova uma forte influência da temperatura sobre a taxa de desenvolvimento da ferrugem da folha do trigo.

Eyal \& Peterson (1967) analisaram o efeito da luz e da temperatura sobre a esporulação de diferentes raças de $P$. recondita. A produção total de esporos não foi afetada pelo escuro em temperaturas altas. Mas, um período de escuro sob baixas temperaturas reduziu a esporulação. A temperatura teve efeito mais pronunciado do que a luz sobre o tempo de maturação das pústulas.

Tomerlin et al. (1983) observaram que não houve esporulação de P. recondita sob $32,3^{\circ} \mathrm{C}$ e, de uma maneira geral, temperaturas iguais ou superiores a $30^{\circ} \mathrm{C}$ foram prejudiciais para a produção de esporos. Porém, não foi observado efeito significativo da temperatura sobre o período infeccioso.

Quando as temperaturas eram menores, associadas a menores intensidades luminosas, Ohm \& Shaner (1976) verificaram o aumento do período latente e a redução do tamanho das pústulas. Houve correlação do maior período latente e do menor tamanho das pústulas com maiores níveis de resistência. Mehta \& Igarashi (1979) sugerem a utilização do período latente para seleção da 
resistência. A resistência de diferentes linhagens de trigo mostrou-se mais estável sob temperaturas mais baixas, ressaltando-se a importância deste fator ambiental para estudos de resistência genética de cereais às ferrugens (Kaul \& Shaner, 1989).

Há um aumento da resistência com o aumento da idade. A quantificação dos parâmetros de resistência parcial é feita de maneira mais satisfatória em plantas adultas. Verificou-se um maior período latente, uma menor freqüência de infeç̧ão e um menor tamanho de pústula em folhas bandeira de plantas de trigo. Indica-se o uso desta folha durante os processos de seleção, nos quais os testes em plântulas teriam a função de uma seleção inicial, economizando tempo e espaço (Broers, 1989a).

Tomerlin et al. (1983) constataram que o período latente foi menor sob temperaturas mais altas, em todos os cultivares e em todos os estádios de desenvolvimento das plantas analisados. Broers \& Wallenburg (1989), por sua vez, observaram que foi maior o efeito de se prolongar o período latente quanto menor fosse a temperatura e, em qualquer uma das temperaturas testadas, este efeito foi maior em planta adulta do que em plântula. A freqüência de infecção é também sensível a temperatura nos dois estádios de desenvolvimento. Porém, o efeito é menor que sobre o período latente.

Cultivares de trigo diferiram entre si quanto ao período latente, à produção de esporos, ao tamanho da pústula e à freqüência de infecção (Tomerlin et al., 1983; Broers, 1989a). Considerando-se o período latente e o tamanho da pústula, as maiores diferenças entre os cultivares de trigo foram observadas quando as temperaturas eram sub-ótimas para o desenvolvimento da doença (Broers \& Wallenburg, 1989). No que se refere ao período latente, ao tamanho da pústula e à freqüência de infecção, as diferenças foram mais pronunciadas no estádio de planta adulta do que em plântula (Broers, 1989a). 
Broers \& Wallenburg (1989) constataram interação raçatemperatura significativa. Em outro trabalho (Denissen, 1991), a freqüência de infecção sofreu influência da raça de ferrugem e do genótipo do cultivar de trigo. Já sobre o período latente, houve efeito da temperatura e do genótipo da planta. Além disso, foi verificada correlação significativa da freqüência de infecção média com o período latente médio.

\subsubsection{Dinâmica da epidemia no campo}

O desenvolvimento da doença no campo está sujeito a variações diurnas e sazonais das condições climáticas, onde a alteração de um fator ambiental pode interferir no efeito de outro (Eversmeyer \& Burleigh, 1970).

Uma vez que uredósporos de ferrugem são transportados eficientemente a longas distâncias por correntes de ar, o inóculo inicial da cultura pode ser de origem local ou exodêmica. Dentre os fatores que são desfavoráveis à sobrevivência dos uredósporos estão a alta incidência de luz e as altas temperaturas (Hwang, 1942).

Nos Estados Unidos, mudanças bruscas de temperatura mostraram-se mais prejudiciais para a sobrevivência que as baixas temperaturas durante o inverno e o início da primavera. A severidade da doença esteve diretamente relacionada à sobrevivência do inóculo no local, entre estações de cultivo. Não havendo sobrevivência, a máxima severidade observada no campo foi inferior a $50 \%$, e maior que este valor, quando o inóculo sobreviveu ao inverno (Eversmeyer et al., 1988).

Sendo o inóculo oriundo de outras regiões, a doença aparece precocemente na cultura do trigo em desenvolvimento (Subba Rao et al., 1989a). A época da chegada do inóculo no campo interfere tanto na severidade da doença 
quanto na sua disseminação (Kolmer, 1990). Durante o transporte a longas distâncias, a temperatura é o fator ambiental de maior importância na sobrevivência de uredósporos de $P$. recondita e $P$. graminis (Eversmeyer \& Kramer, 1994).

A viabilidade dos esporos coletados foi inversamente proporcional à temperatura ambiente. A faixa ótima de temperatura para a viabilidade foi de 12 a $27^{\circ} \mathrm{C}$. Quando as temperaturas eram superiores a $32^{\circ} \mathrm{C}$, observou-se a menor porcentagem de viabilidade (Subba Rao et al., 1989a). Segundo Kolmer (1990), adequadas condições de umidade para a germinação dos esporos e clima mais ameno propiciam maior severidade da doença.

A ocorrência de epidemias e a manifestação da resistência mostraram-se dependentes de condições climáticas favoráveis e de combinações patógeno-hospedeiro (Ohm \& Shaner, 1976; Eversmeyer et al., 1984; Broers, 1989b). A velocidade das epidemias é função da eficiência na produção de esporos, da dispersão e da sobrevivência (Eversmeyer \& Kramer, 1990c).

Burleigh et al. (1972a) observaram relação linear entre o desenvolvimento da ferrugem e a freqüência de temperaturas favoráveis ao fungo. $\mathrm{Na}$ elaboração de equações lineares para a previsão da ferrugem da folha do trigo, assume-se que um dia favorável tem temperatura mínima igual ou superior a $4,4^{\circ} \mathrm{C}$, com quatro horas de água livre, e com a coleta de, no mínimo, um uredósporo por $\mathrm{cm}^{2}$. Obviamente, não foram incluídas no modelo todas as variáveis biológicas e meteorológicas que influem na doença, tanto que as equações desenvolvidas explicam de 67 a $71 \%$ da variação no progresso da doença.

Testando-se dezenove cultivares de trigo quanto à resistência parcial à ferrugem da folha, em condições de campo, observou-se relação inversa entre a taxa de infecção e o nível de resistência. Quanto mais resistente era o cultivar, melhor era a sua performance e menores, os danos. Segundo Mehta \& 
Igarashi (1979), a taxa de infeç̧ão deve ser considerada como um parâmetro básico da resistência parcial. As taxas aparentes de infecção também diferiram entre si, ao se considerar diferentes estádios de crescimento das plantas de trigo em experimento desenvolvido por Subba Rao et al. (1989b).

A resistência do hospedeiro parece diminuir com o aumento da temperatura. O período latente também mostrou-se muito sensível a esta variável climática (Broers, 1989b).

O estádio fenológico do hospedeiro constitui outro fator de influência sobre o desenvolvimento da doença. À medida que a cultura amadureceu, maior foi a incidência de ferrugem (Burleigh et al., 1972a). A eficiência da resistência parcial do trigo à ferrugem mostrou-se reduzida em plântulas e após o florescimento. A densidade de pústulas foi maior no estádio de plântula que nos demais estádios de desenvolvimento. Foi observado maior tamanho de pústulas de ferrugem nas folhas bandeira de plantas de trigo. $\mathrm{O}$ estádio de crescimento influenciou também o período latente da doença, o qual foi maior em plantas adultas (Ohm \& Shaner, 1976).

Em experimento realizado por Barcellos \& Ignaczak (1978), o ataque da ferrugem foi intenso a partir da fase de emborrachamento. Milus (1994) constatou que as epidemias de ferrugem da folha começaram no estádio de folha bandeira e continuaram até o final da estação de cultivo.

Quando a doença foi avaliada pela área abaixo da curva de progresso de doença (AUDPC), constatou-se relação linear inversa entre este parâmetro e o rendimento da cultura. A AUDPC diferiu significativamente nos diferentes estádios de desenvolvimento da cultura e quantidades de inóculo inicial (Subba Rao et al., 1989b). 


\subsection{Modelos de simulação}

Modelo é uma simplificação da realidade. Ele raramente é completo, uma vez que possui algumas, mas não todas as propriedades do sistema que representa (Teng, 1985). Os objetivos na construção de modelos determinam os limites do sistema e o grau da simplificação (Zadoks \& Rabbinge, 1985).

Segundo Campbell \& Madden (1990), há dois tipos principais de modelos: os empíricos e os explanatórios. Os modelos empíricos são desenvolvidos de relações estabelecidas a partir de dados experimentais. Já os explanatórios partem de conceitos previamente definidos, em seguida, são obtidos os dados experimentais. Estabelecem-se relações e, por fim, compreende-se o sistema. Enquanto os modelos empíricos normalmente levam a modelos de previsão, os explanatórios geram os modelos de simulação, os quais poderão, eventualmente, funcionar como modelos de previsão.

Apesar das diferentes classificações dos modelos usados em epidemiologia, os objetivos dos modelos de simulação são bem claros. De acordo com Zadoks \& Rabbinge (1985), através deles serão definidas as relações relevantes do processo de doença. Campbell \& Madden (1990) confirmam que a modelagem de epidemias através da simulação é parte da análise de sistemas. Estes modelos visam o entendimento do desenvolvimento de epidemias e não somente a sua descrição. Com o uso de modelos de simulação é possível visualizar a interferência de cada fator isolado, ou em conjunto, no curso de uma epidemia.

Os modelos de simulação constituem, então, instrumentos de trabalho da epidemiologia comparativa. Uma característica peculiar destes modelos é a possibilidade de "testar idéias", antes de qualquer outra avaliação (Zadoks, 1971). 
Berger \& Bergamin Filho (1990) desenvolveram um modelo de simulação de doenças denominado LESION EXPANSION MODEL. Neste modelo, distinguindo-o de outros, foi incluída uma sub-rotina específica para o crescimento de lesões. Ao final das simulações, o programa fornece em quanto o aparecimento de novas lesões e o crescimento das lesões contribuem para o desenvolvimento da epidemia. Assim, é possível a determinação do peso de cada um destes fatores para o progresso da doença. O programa ainda leva em consideração quatro outros parâmetros epidemiológicos: período latente, proporção de sítios suscetíveis, proporção de área lesionada com esporulação e tamanho inicial das lesões. 


\section{MATERIAL E MÉTODOS}

\subsection{Determinação da área foliar de plantas de trigo}

Visando facilitar a determinação da área foliar de plantas de trigo, foi realizado um ensaio prévio, conduzido separadamente em plantas sadias. Cento e dez folhas do cultivar IAC-24 (sendo metade composta de folhas bandeira e a outra metade, de folhas F-1, as quais correspondem à primeira folha inferior à folha bandeira) foram coletadas e tiveram sua área foliar total medida, cinco vezes cada uma, com o auxílio de um medidor de área foliar portátil (LI-COR modelo LI-3000A).

Cada folha, identificada através de um número seqüencial, teve seu comprimento e sua largura mediana determinados. A correlação entre a área foliar total e o comprimento e/ou a largura foi determinada por regressões lineares utilizando-se como variável dependente o valor real da área foliar total (média de cinco leituras) e como variável independente o comprimento, a largura ou a combinação de ambos.

A escolha do melhor modelo de regressão baseou-se no valor do coeficiente de determinação $\left(R^{2}\right)$. A equação que melhor representou a relação entre a área total da folha (A) e o seu comprimento (C) e a sua largura mediana (L) foi:

$$
\mathrm{A}=1,82+1,54 *((\mathrm{C} * \mathrm{~L}) / 2) \quad\left(\mathrm{R}^{2}=0,95\right)
$$


3.2. Experimentos em condições de ambiente controlado

Os experimentos foram conduzidos com o cultivar de trigo IAC24, que possui suscetibilidade a Bipolaris sorokiniana e a Puccinia recondita f. sp. tritici.

\subsubsection{Avaliação do efeito da temperatura nos parâmetros monocíclicos da helmintosporiose}

\subsubsection{Material vegetal}

Dezesseis sementes de trigo do cultivar IAC-24 foram semeadas em vasos de alumínio com 2,5 litros de solo esterilizado. Os vasos foram mantidos em casa-de-vegetação. Na véspera do dia da inoculação, foi feito o desbaste das plantas, mantendo-se oito plantas por vaso.

\subsubsection{Obtenção e produção do inóculo}

Foi feito o isolamento direto de Bipolaris sorokiniana, a partir de folhas de trigo do cultivar IAC-24, com sintomas de helmintosporiose. As folhas foram obtidas no Campo Demonstrativo e Experimental da Cooperativa AgroPecuária BATAVO, em Ponta Grossa. Foi feita a desinfecção superficial das folhas em álcool $70 \%$, por um minuto, e em solução de hipoclorito de sódio comercial (1:3), por três minutos. A seguir, fragmentos das folhas, de $0,5 \times 0,5$ $\mathrm{cm}$, foram transferidos para placas de Petri com três folhas de papel de filtro umedecido com água destilada. As placas foram mantidas no escuro, sob a temperatura de $24^{\circ} \mathrm{C} \pm 1{ }^{\circ} \mathrm{C}$. Após 48 horas, foi feita a coleta, com agulha 
histológica, dos esporos, os quais foram transferidos para placas com meio de cultura BDA (20 g de dextrose $+18 \mathrm{~g}$ de ágar $+500 \mathrm{ml}$ de caldo de $200 \mathrm{~g}$ de batata em $1000 \mathrm{ml}$ de água destilada $+500 \mathrm{ml}$ de água destilada).

$\mathrm{O}$ fungo foi mantido em BDA, sob a temperatura de $24^{\circ} \mathrm{C} \pm 1^{\circ} \mathrm{C}$ e escuro constante por um período de dezenove dias. Após esse período, as placas foram lavadas com água destilada e com a ajuda de um pincel, os conídios foram liberados. A concentração da suspensão foi calibrada para $6 \times 10^{3}$ esporos por $\mathrm{ml}$, acrescida de 1 gota de Tween 20 por $100 \mathrm{ml}$.

\subsubsection{Inoculação}

As plantas, entre os estádios fenológicos 12 e 14 (duas a quatro folhas abertas) da escala de Zadoks et al. (1974), foram pulverizadas com a suspensão de inóculo. Imediatamente após a inoculação, as plantas foram cobertas com sacos plásticos umedecidos para se formar uma câmara úmida, e mantidas no escuro por um período de 24 horas, após o qual, manteve-se o fotoperíodo de 12 horas de luz. Cada conjunto de cinco vasos foi destinado a uma temperatura diferente: 16,21 e $26^{\circ} \mathrm{C}$. O delineamento experimental foi o inteiramente casualizado com cinco repetições, sendo cada repetição constituída de um vaso com oito plantas.

Este estudo objetivou a abrangência de uma faixa de temperatura em que tanto a ferrugem da folha quanto a helmintosporiose, tivessem seu desenvolvimento favorecido. Segundo dados de literatura, a ferrugem requer temperaturas mais amenas para o seu progresso, enquanto que a segunda doença apresenta desenvolvimento maior e mais rápido sob temperaturas mais altas. 


\subsubsection{Quantificação de parâmetros monocíclicos}

Foi avaliada a segunda folha mais nova de cada uma das plantas, pelo fato de ser esta a folha que se encontrava totalmente expandida em todas as plantas, no momento da inoculação. As avaliações foram iniciadas a partir do aparecimento das primeiras manchas e continuaram até que o número e o tamanho das lesões permanecessem estáveis. As avaliações foram feitas diariamente, determinando-se:

- comprimento e largura mediana da folha para a determinação da área foliar total;

- número de manchas por folha; e

- tamanho das manchas, incluindo o halo amarelado, com o auxílio de uma escala de tamanho de lesões (Figura 01).

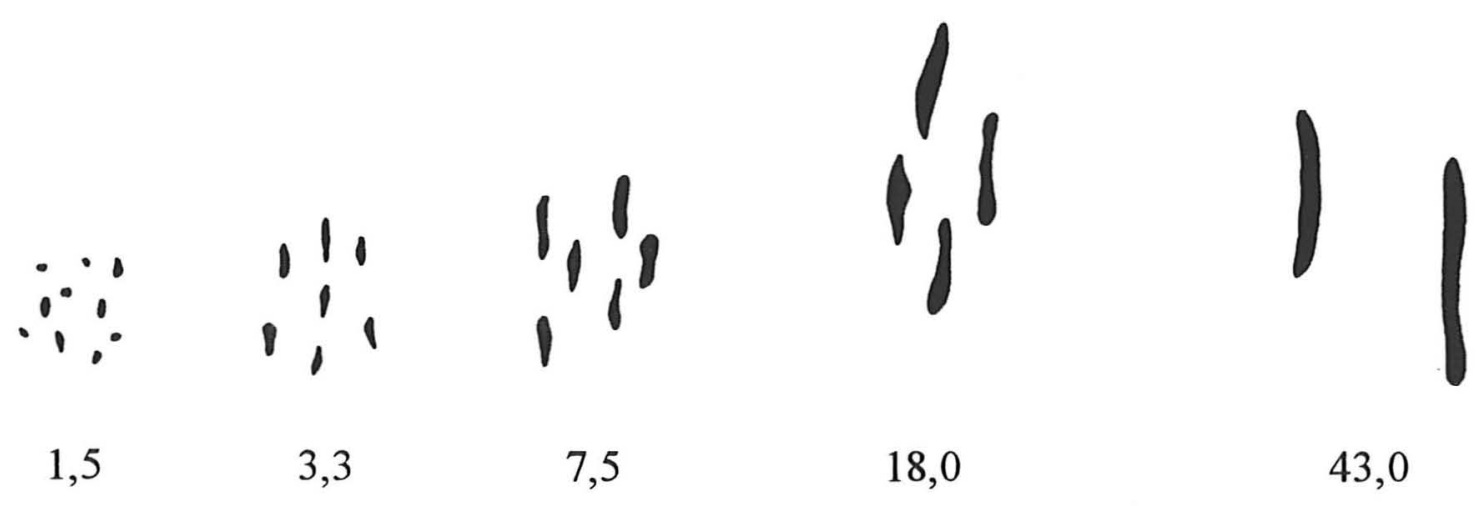

Figura 01. Escala para avaliação do tamanho das lesões da helmintosporiose do trigo (valores em $\mathrm{mm}^{2}$ ).

Com os valores da área foliar $\left(\mathrm{cm}^{2}\right)$ e do número de manchas por folha foi calculado o número de manchas por $\mathrm{cm}^{2}$ de folha, em cada avaliação. Calculou-se, em seguida, a média das plantas por vaso, e a média dos vasos. A partir da média dos dados das cinco repetições de cada tratamento, foi 
estabelecida a curva de progresso da doença, em número de lesões por $\mathrm{cm}^{2} \mathrm{de}$ folha, em função de dias após a inoculação.

Através de regressão não-linear ajustou-se vários modelos para a curva de progresso da doença, em cada uma das temperaturas estudadas. Os modelos testados para o ajuste às curvas foram: o de Gompertz $\left(Y=B_{1}{ }^{*} E X P(-\right.$ $\left.\left.B_{2}{ }^{*} E X P\left(-B_{3} * X\right)\right)\right)$; o monomolecular $\left(Y=B_{1} *\left(1-B_{2}{ }^{*} E X P\left(-B_{3} * X\right)\right)\right)$; o logístico $\left(Y=B_{1} /\left(1+B_{2}{ }^{*} E X P\left(-B_{3}{ }^{*} X\right)\right)\right)$; e uma generalização do modelo logístico com cinco parâmetros $\left(Y=B_{1} /\left(1+E X P\left(B_{2}+B_{3} * X+B_{4} * X^{*} X+B_{5} * X^{* *} 3\right)\right)\right)$ (Hau \& Kranz, 1990), utilizando o programa matemático-estatístico PlotIT for Windows versão 3.1. Os três primeiros modelos são comumente utilizados em estudos de curvas de crescimento, onde $B_{1}$ corresponde à assíntota máxima, $B_{2}$ está relacionado ao inóculo inicial, e $B_{3}$, à taxa aparente de infeç̧ão. Esta generalização do modelo logístico com cinco parâmetros é adequada para casos de curvas que apresentam o formato de uma sigmóide dupla (Hau et al., 1993), onde $B_{l}$ é a assíntota máxima e os demais parâmetros $\left(B_{2}\right.$ a $\left.B_{5}\right)$ estão relacionados com a taxa aparente de infecção.

A escolha do melhor modelo para o ajuste dos dados baseou-se no coeficiente de determinação, na soma dos quadrados dos resíduos, e na estimativa da assíntota da curva de progresso da doença (Campbell \& Madden, 1990). Com base nas equações ajustadas para cada temperatura, foi possível calcular os parâmetros:

- freqüência de infecção, considerada o número máximo de lesões por $\mathrm{cm}^{2}$ de folha, isto é, o valor da assíntota da curva de progresso da doença $\left(B_{1}\right)$; e

- período de incubação, considerado o tempo entre a inoculação e o aparecimento de $50 \%$ das lesões, isto é, o tempo necessário para o aparecimento de lesões de valor igual a $B_{1} / 2$, pois como a umidade relativa das câmaras de crescimento era baixa, não houve a esporulação do fungo. 
Para avaliar o efeito do crescimento da lesão no progresso da doença, outro parâmetro foi calculado. Com os valores de área foliar total, do número de lesões por $\mathrm{cm}^{2}$ de folha e do tamanho das lesões, foi determinada a severidade (porcentagem da área foliar coberta por sintomas) de cada folha, para cada dia de avaliação. Calculou-se, em seguida, a média das plantas por vaso, e a média dos vasos. Assim, foi estabelecida a curva de progresso da doença, em severidade, em função de dias após a inoculação, a partir da média dos dados das cinco repetições de cada tratamento.

Através de regressão não-linear ajustou-se vários modelos para a curva de progresso da doença, em cada uma das temperaturas estudadas. Os modelos testados para o ajuste às curvas de severidade e os parâmetros utilizados para a escolha do melhor modelo foram os mesmos utilizados para as curvas de número de lesões por $\mathrm{cm}^{2}$ de folha em função do tempo.

\subsubsection{Avaliação do efeito da temperatura nos parâmetros monocíclicos da ferrugem da folha}

\subsubsection{Material vegetal}

Dezesseis sementes de trigo do cultivar IAC-24 foram semeadas em vasos de alumínio com 2,5 litros de solo esterilizado. Os vasos foram mantidos em casa-de-vegetação. Na véspera do dia da inoculação, foi feito o desbaste das plantas, mantendo-se oito plantas por vaso.

\subsubsection{Obtenção e produção do inóculo}

O inóculo de Puccinia recondita era proveniente do Instituto Agronômico do Paraná (IAPAR) - Londrina, e foi obtido do cultivar de trigo IAC- 
13. O inóculo liofilizado foi mantido em geladeira, sendo dela retirado 24 horas antes da inoculação.

Adicionou-se $400 \mathrm{ml}$ de água destilada a uma certa quantidade de esporos, e a concentração da suspensão foi calibrada em $6 \times 10^{3}$ uredósporos por $\mathrm{ml}$, acrescida de uma gota de Tween 20 por $100 \mathrm{ml}$.

\subsubsection{Inoculação}

As plantas, entre os estádios fenológicos 12 e 14 (duas a quatro folhas abertas) da escala de Zadoks et al. (1974), foram pulverizadas com a suspensão de inóculo. Imediatamente após a inoculação, as plantas foram cobertas com sacos plásticos umedecidos para se formar uma câmara úmida, e mantidas no escuro por um período de 24 horas, após o qual, manteve-se o fotoperíodo de 12 horas de luz. Cada conjunto de cinco vasos foi destinado a uma temperatura diferente: 16,21 e $26^{\circ} \mathrm{C}$, como no experimento com $B$. sorokiniana (item 3.2.1.3.). O delineamento experimental foi o inteiramente casualizado com cinco repetições, sendo cada repetição constituída de um vaso com oito plantas.

\subsubsection{Quantificação de parâmetros monocíclicos}

Foi avaliada a segunda folha mais nova de cada uma das plantas, como no experimento com B. sorokiniana (item 3.2.1.4.). As avaliações foram iniciadas a partir do aparecimento das primeiras pústulas e continuaram até que o número de lesões permanecesse estável. As avaliações foram feitas diariamente, determinando-se:

- comprimento e largura mediana da folha para a determinação da área foliar total; e

- número de pústulas por folha. 
O tamanho das pústulas $\left(0,5 \mathrm{~mm}^{2}\right)$ foi considerado constante, com base em dados de literatura (Ohm \& Shaner, 1976; Sache \& Vallavieille-Pope, 1993; Lannou et al., 1994b).

Com os valores da área foliar $\left(\mathrm{cm}^{2}\right)$ e do número de pústulas por folha foi calculado o número de pústulas por $\mathrm{cm}^{2}$ de folha, em cada avaliação. Calculou-se, em seguida, a média das plantas por vaso, e a média dos vasos. A partir da média dos dados das cinco repetições de cada tratamento, foi estabelecida a curva de progresso da doença, em número de lesões por $\mathrm{cm}^{2}$ de folha, em função de dias após a inoculação.

Através de regressão não-linear ajustou-se diferentes modelos para a curva de progresso da doença, em cada uma das temperaturas estudadas. Os modelos testados para o ajuste às curvas e os parâmetros utilizados para a escolha do melhor modelo foram os mesmos do experimento com B. sorokiniana (item 3.2.1.4.). Com base nas equações ajustadas para cada temperatura, foi possível calcular os parâmetros:

- freqüência de infecção, considerada o número máximo de lesões por $\mathrm{cm}^{2}$ de folha, isto é, o valor da assíntota da curva de progresso da doença $\left(B_{1}\right)$; e

- período latente, considerado o tempo entre a inoculação e o aparecimento de $50 \%$ das pústulas esporulantes, isto é, o tempo necessário para o aparecimento de lesões de valor igual a $B_{1} / 2$.

Outro parâmetro calculado com os valores de área foliar total, do número de lesões por $\mathrm{cm}^{2}$ de folha e do tamanho das lesões, foi a porcentagem de severidade de cada folha, para cada dia de avaliação. Calculou-se, em seguida, a média das plantas por vaso, e a média dos vasos. Assim, foi estabelecida a curva de progresso da doença, em severidade (porcentagem), em função de dias após a inoculação, a partir da média dos dados das cinco repetições de cada tratamento. 
Através de regressão não-linear ajustou-se diferentes modelos para a curva de progresso da doença, em cada uma das temperaturas estudadas. Os modelos testados para o ajuste às curvas de severidade e os parâmetros utilizados para a escolha do melhor modelo foram os mesmos utilizados para as curvas de número de lesões por $\mathrm{cm}^{2}$ de folha em função do tempo.

3.2.3. Avaliação do efeito da temperatura e do período de molhamento nos parâmetros monocíclicos da helmintosporiose

\subsubsection{Material vegetal}

Nove sementes de trigo do cultivar IAC-24 foram semeadas em vasos de alumínio com 2,5 litros de solo esterilizado. Os vasos foram mantidos em casa-de-vegetação. Na véspera do dia da inoculação, foi feito o desbaste das plantas, mantendo-se quatro plantas por vaso.

\subsubsection{Obtenção e produção do inóculo}

Utilizou-se o mesmo isolado de B. sorokiniana do experimento de avaliação do efeito da temperatura nos parâmetros monocíclicos da helmintosporiose (item 3.2.1.). O fungo foi mantido em BDA, sob a temperatura de $24^{\circ} \mathrm{C} \pm 1{ }^{\circ} \mathrm{C}$ e escuro constante por um período de doze dias. $\mathrm{O}$ inóculo foi preparado como descrito no item 3.2.1.2. 


\subsubsection{Inoculação}

As plantas encontravam-se entre os estádios 21-22 e 43 (perfilhamento, com sete a oito folhas abertas e um a dois perfilhos, até início da dilatação da bainha, respectivamente) da escala de Zadoks et al. (1974). A suspensão do inóculo foi pulverizada sobre a folha bandeira, a primeira (F-1) e a segunda (F-2) folha abaixo da folha bandeira. Imediatamente após a inoculação, as plantas foram cobertas com sacos plásticos umedecidos para se formar uma câmara úmida. Cada conjunto de três vasos foi destinado a uma combinação diferente de temperatura e período de câmara úmida. Foram utilizadas todas as combinações entre 11,16 e $26^{\circ} \mathrm{C}$ e $4,12,16$ e 24 horas de câmara úmida, além de 6 e $31^{\circ} \mathrm{C}$ e 24 horas de câmara úmida. O escuro foi mantido por 24 horas para todos os tratamentos, após o qual, manteve-se o fotoperíodo de 12 horas de luz. O delineamento experimental adotado foi o fatorial, sendo considerados os fatores temperatura e período de câmara úmida como causas de variação, com três repetições, sendo cada repetição constituída de um vaso com quatro plantas.

O objetivo deste experimento foi o de avaliar um maior número de temperaturas que no experimento de avaliação do efeito da temperatura nos parâmetros monocíclicos da helmintosporiose (item 3.2.1.); e avaliar o efeito de diferentes períodos de câmara úmida na quantificação de parâmetros monocíclicos e no desenvolvimento da doença.

\subsubsection{Quantificação de parâmetros monocíclicos}

Foram avaliadas a folha bandeira, a primeira (F-1) e a segunda (F2) folha abaixo da folha bandeira. As avaliações foram iniciadas a partir do aparecimento das primeiras manchas e continuaram até que o número e o tamanho 
das lesões permanecessem estáveis. As avaliações foram feitas diariamente, determinando-se:

- comprimento e largura mediana da folha para a determinação da área foliar total;

- número de manchas por folha; e

- tamanho das manchas, incluindo o halo amarelado, com o auxílio de uma escala de tamanho de lesões (Figura 01).

Com os valores da área foliar $\left(\mathrm{cm}^{2}\right)$ e do número de manchas por folha foi calculado o número de manchas por $\mathrm{cm}^{2}$ de folha, em cada avaliação. Calculou-se, em seguida, a média das três folhas superiores de cada planta, a média das plantas por vaso, e a média dos vasos. A partir da média dos dados das três repetições de cada tratamento, foi estabelecida a curva de progresso da doença, em número de lesões por $\mathrm{cm}^{2}$ de folha, em função de dias após a inoculação.

Através de regressão não-linear ajustou-se vários modelos para a curva de progresso da doença, em cada uma das combinações de temperatura e período de câmara úmida estudadas. Os modelos testados para o ajuste às curvas $\mathrm{e}$ os parâmetros utilizados para a escolha do melhor modelo foram os mesmos do experimento com B. sorokiniana (item 3.2.1.4.).

Com base nas equações ajustadas para cada tratamento, foi possível calcular os parâmetros:

- freqüência de infecção, considerada o número máximo de lesões por $\mathrm{cm}^{2}$ de folha, isto é, o valor da assíntota da curva de progresso da doença $\left(B_{1}\right)$; e

- período de incubação, considerado o tempo entre a inoculação e o aparecimento de $50 \%$ das lesões, isto é, o tempo para $B_{1} / 2$, pois como a umidade relativa das câmaras de crescimento era baixa, não houve a esporulação do fungo. 
Para avaliar o efeito do crescimento da lesão no progresso da doença, outro parâmetro foi calculado. Com os valores de área foliar total, do número de lesões por $\mathrm{cm}^{2}$ de folha e do tamanho das lesões, foi determinada a porcentagem de severidade de cada folha, para cada dia de avaliação. Calculouse, em seguida, a média das três folhas superiores de cada planta, a média das plantas por vaso, e a média dos vasos. Assim, foi estabelecida a curva de progresso da doença, em severidade (porcentagem), em função de dias após a inoculação, a partir da média dos dados das três repetições de cada tratamento.

Através de regressão não-linear ajustou-se vários modelos para a curva de progresso da doença, em cada uma das combinações de temperatura e período de câmara úmida estudadas. Os modelos testados para o ajuste às curvas de severidade foram os mesmos utilizados para as curvas de número de lesões por $\mathrm{cm}^{2}$ de folha em função do tempo.

Os dados de freqüência de infecção e de severidade em cada uma das combinações de temperatura e período de câmara úmida foram ajustados à função Beta-Richards $\left(Z=B_{1} *\left(\left(X-B_{2}\right) * * B_{4}\right) *\left(\left(B_{3}-X\right) * * B_{5}\right)^{*}\left(1-\beta^{*} E X P(-\right.\right.$ $\left.\left.B_{6}{ }^{*} Y\right)\right)^{* *} B_{7}$ ), utilizando-se o programa matemático-estatístico STATISTICA. Foram estimados os valores de 5 e $36^{\circ} \mathrm{C}$, respectivamente, para os parâmetros $B_{2}$ e $B_{3}$, os quais correspondem às temperaturas mínima e máxima para o desenvolvimento da doença. Os valores considerados foram baseados em dados de literatura e em resultados de experimentação. $O$ parâmetro $Z$ é a freqüência de infecção ou a severidade; $X$, a temperatura; $Y$, o período de câmara úmida; e os demais $\left(B_{1}, B_{4}, B_{5}, B_{6}, B_{7}\right.$ e $\left.\beta\right)$, parâmetros do modelo. Assim, foram obtidas superfícies resposta da freqüência de infecção $\mathrm{e}$ da severidade da helmintosporiose a estes dois fatores.

A partir dos resultados dos dois experimentos de helmintosporiose, em condições de ambiente controlado, foi calculada a média dos valores de 
período de incubação nas diferentes temperaturas estudadas $(6,11,16,21,26$ e $31^{\circ} \mathrm{C}$ ). Através de regressão não-linear, utilizando-se o programa matemáticoestatístico STATISTICA, foi feito o ajuste dos dados à função Beta generalizada, $Y=B_{1} *\left(\left(\left(X-B_{2}\right)^{* *} B_{4}\right) *\left(\left(B_{3}-X\right)^{* *} B_{5}\right)\right)$, onde $Y$ é o período de incubação; $X$, a temperatura; $B_{2}$ e $B_{3}$ correspondem, respectivamente, às temperaturas mínima e máxima para o desenvolvimento da doença; e os demais $\left(B_{1}, B_{4}\right.$ e $\left.B_{5}\right)$, parâmetros do modelo. Esta função tem se mostrado muito útil na descrição do efeito da temperatura nos parâmetros de doenças (Hau \& Kranz, 1990).

\subsection{Experimentos em condições de campo}

\subsubsection{Experimento de Ponta Grossa - PR de 1994}

O experimento foi conduzido no Campo Demonstrativo e Experimental da Cooperativa Agro-Pecuária BATAVO.

Foi feita a análise química do solo e a adubação de correção foi de $2000 \mathrm{Kg}$ de calcário/ha. A adubação de base consistiu de $300 \mathrm{Kg} / \mathrm{ha}$ da fórmula 10-28-16 e a de cobertura, $100 \mathrm{Kg} / \mathrm{ha}$ de uréia. Não se dispunha de irrigação no campo.

Foram utilizados os cultivares de trigo IAC-24, recomendado para o plantio no estado de São Paulo, e BR-34, recomendado para o plantio no estado do Paraná; ambos são suscetíveis à mancha foliar causada por B. sorokiniana e à ferrugem da folha. $O$ espaçamento foi de $0,16 \mathrm{~m}$ e a densidade de plantio, 67 sementes por metro linear. A semeadura foi realizada em 14 de junho. A área experimental média foi de $50 \times 73 \mathrm{~m}$, sendo que cada metade da área foi semeada com um dos cultivares. 
Foram estabelecidas oito parcelas (quatro para o cv. IAC-24 e quatro para o BR-34), medindo $4 \times 4 \mathrm{~m}$ cada uma, e espaçadas por 1,5 m. Foram marcadas dez plantas nas cinco linhas centrais de cada parcela, para as avaliações posteriores.

Em função das condições ambientais do local serem favoráveis à infecção dos dois patógenos em estudo, não foram realizadas inoculações na área.

Foram avaliadas a folha bandeira, a F-1 e a F-2, de cada uma das plantas marcadas. As avaliações iniciaram a partir do estádio de bainha toda dilatada (estádio 45 da escala de Zadoks et al., 1974), e continuaram até o início da abertura das anteras (estádio 60 da escala de Zadoks et al., 1974). Foi feita uma avaliação por semana, durante quatro semanas consecutivas, determinandose:

- comprimento e largura mediana da folha para a determinação da área foliar total;

- número de manchas de helmintosporiose por folha;

- tamanho das manchas de helmintosporiose, incluindo o halo amarelado, com o auxílio de uma escala de tamanho de lesões (Figura 01); e

- número de pústulas de ferrugem por folha.

O tamanho das pústulas $\left(0,5 \mathrm{~mm}^{2}\right)$ foi considerado constante, como nos experimentos de ferrugem em condições de ambiente controlado (item 3.2.2.).

Com os valores da área foliar $\left(\mathrm{cm}^{2}\right)$, do número de manchas de helmintosporiose por folha e do número de pústulas de ferrugem por folha, foram calculados o número de manchas por $\mathrm{cm}^{2}$ de folha e o número de pústulas por $\mathrm{cm}^{2}$ de folha, em cada avaliação. Calculou-se, em seguida, a média das três folhas superiores de cada planta e a média das plantas por parcela. A partir dos dados das quatro parcelas de cada cultivar, foram estabelecidas as curvas de progresso 
das duas doenças, em número de lesões por $\mathrm{cm}^{2}$ de folha, em função de dias após a semeadura.

Através de regressão não-linear ajustou-se vários modelos para as curvas de progresso das doenças, em cada uma das parcelas. Os modelos testados para o ajuste às curvas foram os mesmos descritos no item 3.2.1.4. Calculou-se, ainda, a área sob a curva de progresso da doença, da helmintosporiose e da ferrugem da folha, de cada uma das parcelas de cada cultivar.

Outro parâmetro calculado com os valores de área foliar total, do número de lesões por $\mathrm{cm}^{2}$ de folha e do tamanho das lesões, foi a severidade (porcentagem) de cada folha, de cada doença, para cada dia de avaliação. Calculou-se, em seguida, a média das três folhas superiores de cada planta e a média das plantas por parcela. Assim, foram estabelecidas as curvas de progresso das duas doenças, em severidade, em função de dias após a semeadura, a partir dos dados das quatro parcelas de cada cultivar.

Através de regressão não-linear ajustou-se vários modelos para as curvas de progresso das doenças, de cada uma das quatro parcelas. Os modelos testados para o ajuste às curvas de severidade foram os mesmos utilizados para as curvas de número de lesões por $\mathrm{cm}^{2}$ de folha em função do tempo. Calculou-se, ainda, a área sob a curva de progresso da doença, da helmintosporiose e da ferrugem da folha, de cada uma das parcelas de cada cultivar, para fins de análise estatística.

Além das plantas marcadas, semanalmente eram feitas amostragens sistemáticas de folhas no restante da área, para cada um dos cultivares.

Ao se trabalhar com amostragens, deve-se definir um número mínimo ou ótimo de amostras, de modo a facilitar a pesquisa e atingir um certo nível de precisão. Preliminarmente, deve-se ter uma estimativa da média e da variabilidade da população a ser amostrada (Campbell \& Madden, 1990). 
Assim, numa primeira amostragem, coletou-se 50 folhas de cada cultivar. Calculou-se a média e a variância do número de lesões de ferrugem das 50 folhas. Estabeleceu-se o valor de $10 \%$ para o coeficiente de variação. Considerando-se que as plantas doentes apresentavam distribuição casualizada, utilizou-se a fórmula (Campbell \& Madden, 1990):

$$
\mathrm{n}=\frac{\mathrm{s}^{2}}{\overline{\mathrm{x}}^{2} \cdot \mathrm{C}^{2}}
$$

onde:

$\mathrm{n}=$ número de amostras,

$\mathrm{s}^{2}=$ estimativa da variância,

$\overline{\mathrm{x}}=$ estimativa da média,

$\mathrm{C}=$ coeficiente de variação,

para se determinar o número mínimo de amostras da população de plantas. Considerando-se entre os dois cultivares, o maior número de amostras, determinou-se que seriam coletadas 60 folhas de cada cultivar, semanalmente.

Estas folhas amostradas foram avaliadas da mesma maneira que as plantas marcadas.

As amostragens iniciaram a partir do aparecimento da folha bandeira nas plantas (estádio 39 da escala de Zadoks et al., 1974), e continuaram até o início da abertura das anteras (estádio 60 da escala de Zadoks et al., 1974). Foi feita uma avaliação por semana, durante cinco semanas consecutivas, determinando-se:

- comprimento e largura mediana da folha para a determinação da área foliar total;

- número de manchas de helmintosporiose por folha; 
- tamanho das manchas de helmintosporiose, incluindo o halo amarelado, com o auxílio de uma escala de tamanho de lesões (Figura 01); e

- número de pústulas de ferrugem por folha.

O tamanho das pústulas $\left(0,5 \mathrm{~mm}^{2}\right)$ foi considerado constante, como na avaliação das plantas marcadas.

Com os valores da área foliar $\left(\mathrm{cm}^{2}\right)$, do número de manchas de helmintosporiose por folha e do número de pústulas de ferrugem por folha, foram calculados o número de manchas por $\mathrm{cm}^{2}$ de folha e o número de pústulas por $\mathrm{cm}^{2}$ de folha, em cada avaliação. A partir da média dos dados das folhas amostradas de cada cultivar, foram estabelecidas as curvas de progresso das duas doenças, em número de lesões por $\mathrm{cm}^{2}$ de folha, em função de dias após a semeadura.

Outro parâmetro calculado com os valores de área foliar total, do número de lesões por $\mathrm{cm}^{2}$ de folha e do tamanho das lesões, foi a porcentagem de severidade de cada folha, de cada doença, para cada dia de avaliação. Assim, foram estabelecidas as curvas de progresso das duas doenças, em porcentagem de severidade, em função de dias após a semeadura, a partir da média dos dados das folhas amostradas de cada cultivar.

\subsubsection{Experimento de Ponta Grossa - PR de 1995}

O experimento foi instalado no mesmo local que o do ano de 1994.

Não foi feita adubação de correção no solo. A adubação de base foi de $300 \mathrm{Kg} /$ ha da fórmula 8-30-16 e a de cobertura, $150 \mathrm{Kg} / \mathrm{ha}$ de sulfato de amônia. Como no ano anterior, a cultura não foi irrigada e foi adotado o mesmo delineamento experimental. As avaliações também foram idênticas e foram iniciadas a partir da emergência de metade da inflorescência (estádio 54 da escala 
de Zadoks et al., 1974), e continuaram até o florescimento pleno da cultura (estádio 68 da escala de Zadoks et al., 1974).

Com os valores da área foliar $\left(\mathrm{cm}^{2}\right)$, do número de manchas de helmintosporiose por folha e do número de pústulas de ferrugem por folha foram calculados o número de manchas por $\mathrm{cm}^{2}$ de folha e o número de pústulas por $\mathrm{cm}^{2}$ de folha, em cada avaliação. Calculou-se, em seguida, a média das três folhas superiores de cada planta e a média das plantas por parcela. A partir dos dados das quatro parcelas de cada cultivar, foram estabelecidas as curvas de progresso das duas doenças, em número de lesões por $\mathrm{cm}^{2}$ de folha, em função de dias após a semeadura.

Através de regressão não-linear ajustou-se vários modelos para as curvas de progresso das doenças, em cada uma das parcelas. Os modelos testados para o ajuste às curvas foram os mesmos descritos no item 3.2.1.4. Calculou-se, ainda, a área sob a curva de progresso da doença, da helmintosporiose e da ferrugem da folha, de cada uma das parcelas de cada cultivar, para fins de análise estatística.

Outro parâmetro calculado com os valores de área foliar total, do número de lesões por $\mathrm{cm}^{2}$ de folha e do tamanho das lesões, foi a porcentagem de severidade de cada folha, de cada doença, para cada dia de avaliação. Calculouse, em seguida, a média das três folhas superiores de cada planta e a média das plantas por parcela. Assim, foram estabelecidas as curvas de progresso das duas doenças, em porcentagem de severidade, em função de dias após a semeadura, a partir dos dados das quatro parcelas de cada cultivar.

Através de regressão não-linear ajustou-se vários modelos para as curvas de progresso das doenças, em cada uma das quatro parcelas. Os modelos testados para o ajuste às curvas de severidade foram os mesmos utilizados para as curvas de número de lesões por $\mathrm{cm}^{2}$ de folha em função do tempo. Calculou-se, ainda, a área sob a curva de progresso da doença, para a helmintosporiose e para a 
ferrugem da folha, para cada uma das parcelas de cada cultivar, para fins de análise estatística.

No ano de 1994, o cultivar IAC-24 ocupava a parte mais alta do terreno, enquanto que o BR-34 situava-se na parte mais baixa da área. Para evitar efeito do ambiente sobre o desenvolvimento das doenças e dos cultivares, a posição de cada cultivar foi invertida no ano de 1995 . Neste ano, não foi feita amostragem de folhas no campo. No ano anterior, a amostragem tinha o objetivo de garantir a avaliação das doenças, caso elas não ocorressem nas parcelas. Com base nos resultados obtidos em 1994, decidiu-se pela não realização das amostragens.

\subsection{Estudos de simulação}

Teve-se como instrumento de estudo um modelo desenvolvido por Berger (Berger \& Bergamin Filho, 1990), denominado LESION EXPANSION MODEL, escrito em linguagem Basic, que simula o desenvolvimento de doenças, com e sem o crescimento de lesões.

Os parâmetros a serem fornecidos na entrada dos dados são período latente, em dias; taxa diária de expansão de lesões, em mm por dia; proporção de sítios suscetíveis; máxima taxa básica de infecção, em lesões por lesão por dia; proporção de área lesionada com esporulação e tamanho inicial das lesões, em $\mathrm{mm}^{2}$. O modelo utiliza a equação logística para caracterizar o progresso da doença.

Para cada dia simulado, todos os sítios do hospedeiro são agrupados em um conjunto chamado "cohort". São considerados os tecidos sadio, latente e infeccioso. O programa calcula os valores da proporção de doença e do seu logito, para cada dia de simulação. As simulações são feitas até que a 
proporção de doença seja de 0,5 ou até que o dia simulado seja o quinquagésimo. Ao final das simulações, o programa fornece em quanto o aparecimento de novas lesões e o crescimento das lesões contribuem para o desenvolvimento da epidemia. Desta forma, é possível determinar o peso de cada um destes fatores para o progresso da doença.

Para os estudos de simulação, foram utilizados os resultados médios obtidos nos experimentos em condições de ambiente controlado e em condições de campo (Tabela 01). Foram feitas, ainda, outras simulações fixandose cinco dos seis parâmetros e alterando-se o valor do sexto parâmetro. Estas alterações do valor observado eram da ordem de $20 \%$, sendo tanto positivas quanto negativas. Assim, foram feitas treze simulações para cada patossistema em estudo. Este procedimento visou avaliar o efeito de mudanças de cada um dos parâmetros sobre o desenvolvimento das epidemias.

Tabela 01. Parâmetros iniciais das simulações da helmintosporiose e da ferrugem da folha do trigo, com o programa LESION EXPANSION MODEL (Berger \& Bergamin Filho, 1990).

\begin{tabular}{lcc}
\hline & Helmintosporiose & Ferrugem da folha \\
\hline Período latente (dias) & 7 & 5 \\
Taxa de expansão das lesões (mm/dia) & 0,20 & 0 \\
$\begin{array}{l}\text { Proporção de sítios suscetíveis } \\
\text { Máxima taxa básica de infecção }\end{array}$ & 0,05 & 1,00 \\
$(($ lesões/lesão)/dia) & 4 & 6 \\
Proporção de área lesionada com & & \\
esporulação & 0,01 & 1,00 \\
Tamanho inicial das lesões $\left(\mathrm{mm}^{2}\right)$ & 1,8 & 0,5 \\
\hline
\end{tabular}




\section{RESULTADOS E DISCUSSÃO}

\subsection{Experimentos em condições de ambiente controlado}

\subsubsection{Efeito da temperatura nos parâmetros monocíclicos da helmintosporiose e da ferrugem da folha}

As equações que melhor se ajustaram aos dados de freqüência de infecção e de severidade da helmintosporiose e da ferrugem da folha do trigo, em função da temperatura, estão apresentadas na Tabela 02 , com os respectivos coeficientes de determinação.

Para os dados de progressão do número de lesões de helmintosporiose por $\mathrm{cm}^{2}$, em função do tempo, obtidos sob $16^{\circ} \mathrm{C}$, a generalização do modelo logístico com cinco parâmetros apresentou o melhor ajuste, e para os dados de 21 e $26^{\circ} \mathrm{C}$ foi o modelo logístico que apresentou o melhor ajuste. Os ajustes dos modelos aos dados apresentaram coeficientes de determinação iguais ou superiores a 0,94 . A temperatura de $26^{\circ} \mathrm{C}$ mostrou-se como a mais favorável, seguida, respectivamente, pelas temperaturas de 21 e $16^{\circ} \mathrm{C}$ (Figura 02-A). Sob $26^{\circ} \mathrm{C}$, observa-se que o valor inicial do número de lesões por $\mathrm{cm}^{2}$ equivale ao máximo verificado naquela temperatura. Este fato pode ser explicado pela coalescência das lesões, fato comum ao desenvolvimento dos sintomas da helmintosporiose (Mehta, 1978; Cardoso \& Kimati, 1980; Mehta, 1993) e também de outras manchas foliares (Berger, 1973; Shaner \& Buechley, 1995; 
Bergamin Filho \& Amorim, 1996). Na temperatura de $16^{\circ} \mathrm{C}$, o número de lesões por $\mathrm{cm}^{2}$ de folha, apresentou-se próximo de zero ao longo das avaliações.

Tabela 02. Equações, e respectivos coeficientes de determinação $\left(\mathrm{R}^{2}\right)$, que melhor se ajustaram aos dados de freqüência de infecção (FI), em número de lesões por $\mathrm{cm}^{2}$, e de severidade (SEV), em porcentagem, da helmintosporiose $(\mathrm{H})$ e da ferrugem da folha $(\mathrm{F})$ do trigo, em função da temperatura $(\mathrm{T})$, em graus centígrados, através de regressões nãolineares.

\begin{tabular}{|c|c|}
\hline Equação & $\mathrm{R}^{2}$ \\
\hline $\mathrm{FI}_{\mathrm{H} T 16^{\circ} \mathrm{C}}=0,12 /(1+\mathrm{EXP}(2,43+(-0,24) * \mathrm{~T}+(-0,62 \mathrm{E}-1) * \mathrm{~T} * \mathrm{~T}+(0,32 \mathrm{E}-2) * \mathrm{~T} * * 3))$ & 0,99 \\
\hline $\mathrm{FI}_{\mathrm{H} \mathrm{T} 21{ }^{\circ} \mathrm{C}}=1,45 /\left(1+1,54 * \mathrm{EXP}\left(-0,61^{*} \mathrm{~T}\right)\right)$ & 0,94 \\
\hline $\mathrm{FI}_{\mathrm{H} \mathrm{T26}}{ }^{\circ}=4,01 /(1+0,22 * \mathrm{EXP}(0,20 * \mathrm{~T}))$ & 0,94 \\
\hline $\mathrm{SEV}_{\mathrm{H} \mathrm{T} 16^{\circ} \mathrm{C}}=0,29 /\left(1+\mathrm{EXP}\left(5,54+(-1,50) * \mathrm{~T}+0,13^{*} \mathrm{~T} * \mathrm{~T}+(-0,41 \mathrm{E}-2) * \mathrm{~T}^{*} * 3\right)\right)$ & 0,99 \\
\hline $\mathrm{SEV}_{\mathrm{H} \text { T21 }}{ }^{\circ}=3,98 /(1+2,32 * \operatorname{EXP}(-0,24 * \mathrm{~T}))$ & 0,99 \\
\hline $\mathrm{SEV}_{\mathrm{H} \mathrm{T26}}{ }^{\circ} \mathrm{C}=8,15 /\left(1+\mathrm{EXP}\left((-13,06)+8,65^{*} \mathrm{~T}+(-1,82)^{*} \mathrm{~T} * \mathrm{~T}+0,11^{*} \mathrm{~T} * * 3\right)\right)$ & 0,82 \\
\hline $\mathrm{FI}_{\mathrm{F} \mathrm{T} 16^{\circ} \mathrm{C}}=9,28 /(1+\mathrm{EXP}(27,14+(-6,34) * \mathrm{~T}+0,50 * \mathrm{~T} * \mathrm{~T}+(-0,13 \mathrm{E}-1) * \mathrm{~T} * * 3))$ & 0,99 \\
\hline $\mathrm{FI}_{\mathrm{F} \text { T21 }}{ }^{\circ} \mathrm{C}=6,10 /\left(1+\mathrm{EXP}\left((-10,52)+2,74 * \mathrm{~T}+(-0,20)^{*} \mathrm{~T} * \mathrm{~T}+(0,38 \mathrm{E}-2) * \mathrm{~T}^{*} * 3\right)\right)$ & 0,99 \\
\hline $\mathrm{FI}_{\mathrm{F} 26^{\circ} \mathrm{C}}=4,20 /\left(1+\mathrm{EXP}\left((-5,90)+2,33^{*} \mathrm{~T}+(-0,21)^{*} \mathrm{~T}^{*} \mathrm{~T}+(0,49 \mathrm{E}-2) * \mathrm{~T} * * 3\right)\right)$ & 0,99 \\
\hline $\mathrm{SEV}_{\mathrm{FT} 16^{\circ} \mathrm{C}}=4,64 /(1+\mathrm{EXP}(26,98+(-6,30) * \mathrm{~T}+0,49 * \mathrm{~T} * \mathrm{~T}+(-0,13 \mathrm{E}-1) * \mathrm{~T} * * 3))$ & 0,99 \\
\hline $\mathrm{SEV}_{\mathrm{FT} \text { T2 }}{ }^{\circ} \mathrm{c}=3,06 /(1+\mathrm{EXP}((-10,92)+2,84 * \mathrm{~T}+(-0,21) * \mathrm{~T} * \mathrm{~T}+(0,41 \mathrm{E}-2) * \mathrm{~T} * * 3))$ & 0,99 \\
\hline $\mathrm{SEV}_{\mathrm{FT} 26^{\circ} \mathrm{C}}=2,11 /(1+\mathrm{EXP}((-8,72)+3,00 * \mathrm{~T}+(-0,26) * \mathrm{~T} * \mathrm{~T}+(0,61 \mathrm{E}-2) * \mathrm{~T} * * 3))$ & 0,99 \\
\hline
\end{tabular}

Para os dados de severidade da helmintosporiose obtidos sob 16 e $26^{\circ} \mathrm{C}$, a generalização do modelo logístico com cinco parâmetros apresentou o melhor ajuste e, para os dados de $21^{\circ} \mathrm{C}$ foi o modelo logístico que apresentou o melhor ajuste. Os ajustes dos modelos apresentaram coeficientes de determinação 
iguais ou superiores a 0,82 . Em termos de severidade, a temperatura de $26^{\circ} \mathrm{C}$ também foi a mais favorável, sendo seguida pelas temperaturas de 21 e $16^{\circ} \mathrm{C}$, respectivamente (Figura 02-C).

De posse das curvas de progresso da doença, foram quantificados os parâmetros monocíclicos freqüência de infecção e período de incubação da helmintosporiose (Tabelas 03 e 04 ), e foi calculada a porcentagem máxima de severidade, nas três temperaturas estudadas (Tabela 05).

Os resultados da helmintosporiose coincidem com aqueles obtidos por outros autores (Clark \& Dickson, 1958; Wood, 1962; Luz \& Bergstrom, 1986). Clark \& Dickson (1958) avaliaram a influência da temperatura sobre a helmintosporiose, em folhas destacadas de cevada. Foram estudadas as temperaturas de $16,20,24$ e $28^{\circ} \mathrm{C}$. Os sintomas foram mais intensos e de desenvolvimento mais rápido, quanto maior era a temperatura. Ao serem testados diferentes isolados do fungo, alguns deles não foram capazes de causar doença, sob 16 e $20^{\circ} \mathrm{C}$. Os autores afirmam que as temperaturas mais baixas, geralmente, são prejudiciais ao desenvolvimento da doença.

Wood (1962), com resultados semelhantes, justifica que o melhor desenvolvimento da doença ocorre sob temperaturas desfavoráveis ao desenvolvimento da planta. Ou seja, o efeito da temperatura seria principalmente sobre o hospedeiro. Neste trabalho, foram analisados diferentes isolados do fungo em plantas de trigo, cevada e aveia. Estas culturas, que são típicas de clima temperado, apresentam melhor desenvolvimento sob temperaturas amenas. Entretanto, Duczek \& Wildermuth (1992) observaram o decréscimo da esporulação de Bipolaris sorokiniana, quanto menor era a temperatura. Este fator ambiental exerceria, então, efeito também sobre o patógeno. 

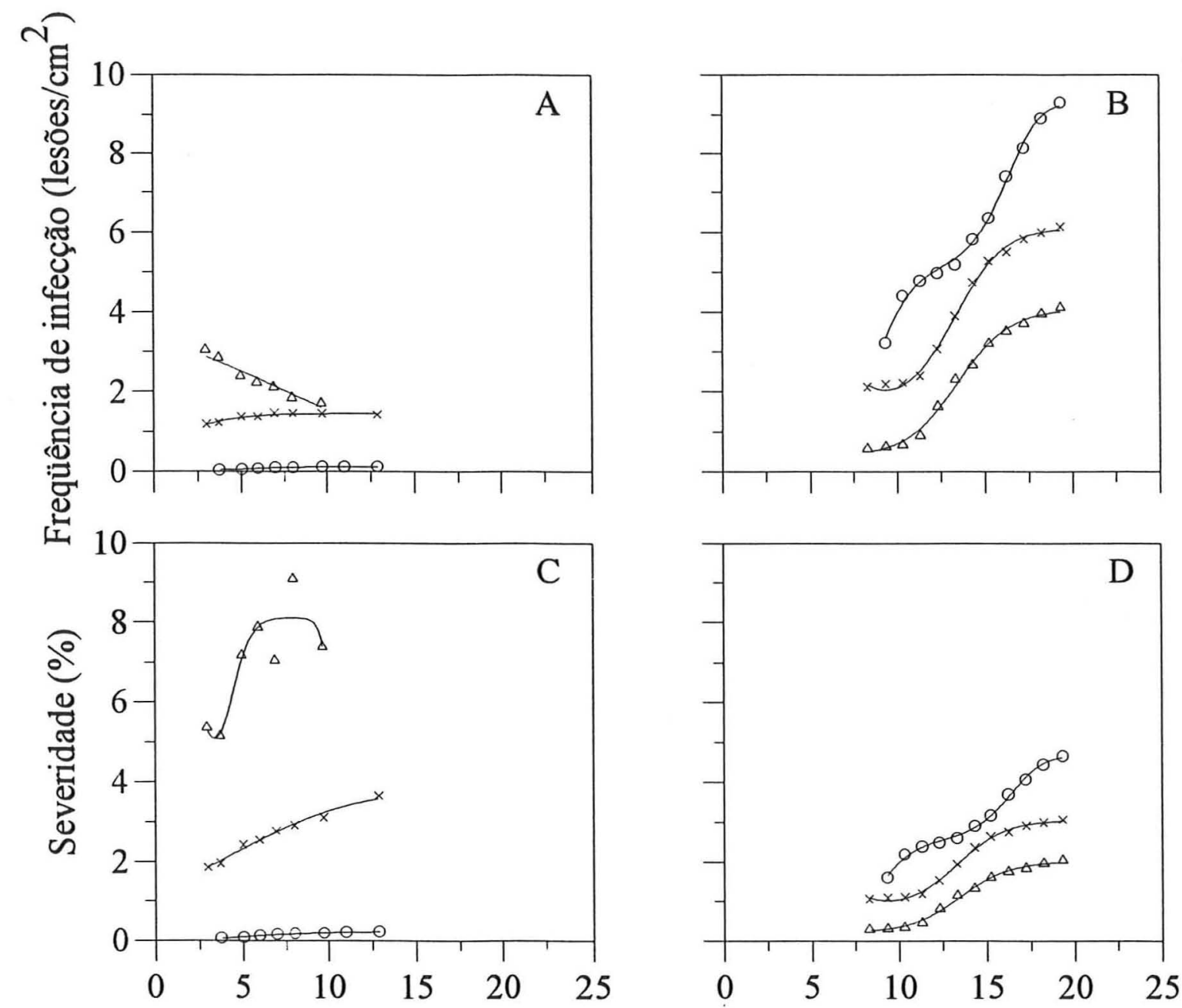

Dias após a inoculação

- $16^{\circ} \mathrm{C} \times 21^{\circ} \mathrm{C} \triangle 26^{\circ} \mathrm{C}$

Figura 02. Curvas de progresso dos dados de freqüência de infecção (A, B), em número de lesões por $\mathrm{cm}^{2}$, e severidade $(\mathrm{C}, \mathrm{D})$, em porcentagem, da helmintosporiose $(\mathrm{A}, \mathrm{C})$ e da ferrugem da folha $(\mathrm{B}, \mathrm{D})$ do trigo, nas temperaturas de 16,21 e $26^{\circ} \mathrm{C}$, e 24 horas de câmara úmida. Cada ponto representa a média de cinco repetições. 
Tabela 03. Freqüência de infecção, em número de lesões por $\mathrm{cm}^{2}$, da helmintosporiose e da ferrugem da folha do trigo, em plântulas do cultivar IAC-24 (estádios 12 a 14 da escala de Zadoks et al., 1974), incubadas em diferentes temperaturas, sob 24 horas de câmara úmida. Valores estimados pelas regressões não-lineares dos dados (exceto para a helmintosporiose a $26^{\circ} \mathrm{C}$ ). Média de cinco repetições.

\begin{tabular}{cccc}
\hline Doença & \multicolumn{3}{c}{ Temperatura } \\
& $16^{\circ} \mathrm{C}$ & $21^{\circ} \mathrm{C}$ & $26^{\circ} \mathrm{C}$ \\
\hline Helmintosporiose & 0,12 & 1,45 & $3,03^{*}$ \\
Ferrugem da folha & 9,28 & 6,10 & 4,20 \\
\hline
\end{tabular}

Valor observado.

Tabela 04. Período de incubação da helmintosporiose e período latente da ferrugem da folha do trigo, em dias, em plântulas do cultivar IAC-24 (estádios 12 a 14 da escala de Zadoks et al., 1974), incubadas em diferentes temperaturas, sob 24 horas de câmara úmida. Valores estimados pelas regressões não-lineares dos dados (exceto para a helmintosporiose a 21 e $26^{\circ} \mathrm{C}$ ). Média de cinco repetições.

\begin{tabular}{cccc}
\hline Doença & \multicolumn{3}{c}{ Temperatura } \\
& $16^{\circ} \mathrm{C}$ & $21^{\circ} \mathrm{C}$ & $26^{\circ} \mathrm{C}$ \\
\hline Helmintosporiose & 5,13 & $<3,01^{*}$ & $<2,98^{*}$ \\
Ferrugem da folha & 11,00 & 12,18 & 13,25 \\
\hline
\end{tabular}

\footnotetext{
Valor observado.
} 
Tabela 05. Severidade, em porcentagem, da helmintosporiose e da ferrugem da folha do trigo, em plântulas do cultivar IAC-24 (estádios 12 a 14 da escala de Zadoks et al., 1974), incubadas em diferentes temperaturas, sob 24 horas de câmara úmida. Valores estimados pelas regressões não-lineares dos dados. Média de cinco repetições.

\begin{tabular}{cccc}
\hline Doença & \multicolumn{3}{c}{ Temperatura } \\
& $16^{\circ} \mathrm{C}$ & $21^{\circ} \mathrm{C}$ & $26^{\circ} \mathrm{C}$ \\
\hline Helmintosporiose & 0,29 & 3,98 & 8,15 \\
Ferrugem da folha & 4,64 & 3,06 & 2,11 \\
\hline
\end{tabular}

Luz \& Bergstrom (1986) estudaram o efeito da temperatura sobre o desenvolvimento da helmintosporiose em cultivares de trigo com diferentes níveis de resistência. Foram analisadas as temperaturas de $12,18,20,24$ e $28^{\circ} \mathrm{C}$, com 24 horas de câmara úmida. As plantas foram inoculadas no estádio de cinco folhas com três perfilhos, e foi utilizada a concentração de inóculo de $10^{5}$ conídios por ml. Houve um aumento do número de lesões e da severidade da doença com o aumento da temperatura. Observou-se, ainda, que os cultivares diferiram estatisticamente entre si, quanto à severidade da doença, somente na mais baixa e na mais alta temperatura, respectivamente, 12 e $28^{\circ} \mathrm{C}$.

O trabalho de Luz \& Bergstrom (1986) é um dos poucos a considerar a quantificação de parâmetros monocíclicos da helmintosporiose para avaliar o efeito da temperatura sobre a doença. Ao se considerar o cultivar suscetível, diferenças estatísticas, quanto ao número de lesões por $\mathrm{cm}^{2}$, puderam ser verificadas nas cinco temperaturas analisadas. Porém, no que se refere ao período de incubação, diferenças significativas só foram observadas nas 
temperaturas mais baixas $\left(12\right.$ e $\left.18^{\circ} \mathrm{C}\right)$, as quais diferiram estatisticamente das demais temperaturas $\left(20,24\right.$ e $\left.28^{\circ} \mathrm{C}\right)$. O efeito da temperatura é, portanto, importante para a infecção, mas não para a colonização da planta pelo fungo. Foram observadas também diferenças estatísticas entre os valores de severidade da doença, em função da temperatura. Quanto menor era o nível de resistência do cultivar, maiores eram as diferenças verificadas entre as temperaturas, considerando-se tanto o número de lesões por $\mathrm{cm}^{2}$, como a porcentagem de severidade da helmintosporiose. Independentemente do cultivar considerado, quanto maior a temperatura, melhor e mais rápido o desenvolvimento da doença.

A generalização do modelo logístico com cinco parâmetros apresentou o melhor ajuste para os dados de progressão do número de lesões por $\mathrm{cm}^{2}$ e da severidade da ferrugem, em função do tempo, nas três temperaturas analisadas $\left(16,21\right.$ e $\left.26^{\circ} \mathrm{C}\right)$. Os ajustes dos modelos aos dados, nas três temperaturas estudadas, apresentaram coeficientes de determinação iguais a 0,99. A influência da temperatura, tanto sobre o número de lesões por $\mathrm{cm}^{2}$ (Figura 02B), quanto sobre a severidade (Figura 02-D), mostrou-se de maneira inversa àquela dos dados de helmintosporiose. Quanto menor era a temperatura, maiores eram o número de lesões por $\mathrm{cm}^{2}$ e a severidade da ferrugem. Segundo Kaul \& Shaner (1989), a influência da temperatura sobre a ferrugem da folha do trigo é maior sobre a interação patógeno-hospedeiro, que sobre cada um deles separadamente.

A Tabela 03 apresenta os valores da freqüência de infecção da ferrugem. Broers \& Wallenburg (1989), trabalhando com faixas de temperatura mais amplas, verificaram que não houve efeito significativo da temperatura sobre a freqüência de infecção. Entretanto, os autores observaram o aumento da freqüência de infecção da doença em temperaturas próximas dos $16^{\circ} \mathrm{C}$, como no presente experimento. 
Ao se analisar o período latente da ferrugem (Tabela 04), constatase uma tendência de aumento no valor deste parâmetro, com o aumento da temperatura. Vários são os trabalhos na literatura que indicam a diminuição do período latente com o aumento da temperatura (Eyal \& Peterson, 1967; Eversmeyer et al., 1980; Tomerlin et al., 1983; Broers \& Wallenburg, 1989; Kaul \& Shaner, 1989; Denissen, 1991), numa relação inversa da que foi observada no presente experimento. Eversmeyer et al. (1980) explicam que quanto mais próxima a temperatura estiver da faixa ideal para o desenvolvimento da doença, menor seu efeito sobre o período latente. Esta amplitude de variação dos valores de período latente da ferrugem é menor em plântulas que em plantas adultas de trigo (Tomerlin et al., 1983). Segundo Broers \& Wallenburg (1989), esta variação é também dependente da combinação cultivar-raça, podendo caracterizar-se como não significativa.

Comparando-se os resultados de freqüência de infecção da helmintosporiose e da ferrugem (Tabela 03), verifica-se o maior número de lesões por $\mathrm{cm}^{2}$ da ferrugem, independentemente da temperatura. Ao se considerar a severidade (Tabela 05), a helmintosporiose supera a ferrugem, conquistando maior área de tecido do hospedeiro, através do crescimento de suas lesões, apesar do menor número de lesões por $\mathrm{cm}^{2}$. O tamanho das pústulas de Puccinia recondita permaneceu constante ao longo de todo o experimento, conforme observação anterior de Sache \& Vallavieille-Pope (1993). Em estudos monocíclicos e de simulação, para a comparação de duas ferrugens do trigo, a da folha e a estriada, estes autores evidenciaram para cada um dos patógenos diferentes estratégias visando o desenvolvimento de epidemias. P. striiformis desenvolveu muito menos lesões que $P$. recondita, mas nas simulações, o crescimento das lesões da ferrugem estriada, garante a esta doença potencial semelhante ao da ferrugem da folha para causar epidemias. Ou seja, a menor capacidade de $P$. striiformis em causar um grande número de infecções seria 
compensada pela sua capacidade em aumentar o tamanho de suas lesões, confirmando a teoria de Aust et al. (1980). De acordo com estes autores, a deficiência de um dos fatores da doença - seja ele, referente ao patógeno, ao hospedeiro, ou ao ambiente - é compensada pela maior eficiência de outro fator. Esta situação pôde ser visualizada comparando-se o comportamento de $B$. sorokiniana com o de $P$. recondita, em condições de ambiente controlado.

Os requerimentos de temperatura destes patógenos para 0 desenvolvimento das respectivas doenças são diferentes. Enquanto a helmintosporiose é favorecida por temperaturas mais altas, a ferrugem da folha tem maior desenvolvimento sob temperaturas mais amenas, o que está de acordo com a literatura (Mehta, 1978; Cardoso \& Kimati, 1980; Wiese, 1987; Mehta, 1993). Apesar de ter sido analisado somente o efeito de três temperaturas nos parâmetros monocíclicos das doenças, pode-se supor que $P$. recondita utilize uma faixa de temperatura mais ampla do que $B$. sorokiniana para causar infecção. Com o aumento da temperatura, de 16 para 21 e $26^{\circ} \mathrm{C}, P$. recondita apresentou uma redução na proporção relativa da freqüência de infecção de 1,00 para 0,66 e 0,45 , respectivamente. Enquanto que para B. sorokiniana, a redução foi de 1,00 para 0,48 e 0,04 , respectivamente, com a diminuição da temperatura de 26 para 21 e $16^{\circ} \mathrm{C}$. Wiese \& Ravenscroft (1979) comentam que tanto a germinabilidade quanto a infectividade de $P$. recondita são reduzidas sob temperaturas maiores que $20^{\circ} \mathrm{C}$, e Clark \& Dickson (1958) verificaram exemplos de isolados de $B$. sorokiniana que não foram capazes de causar infecção sob 20 e $16^{\circ} \mathrm{C}$. 
4.1.2. Efeito da temperatura e do período de molhamento nos parâmetros monocíclicos da helmintosporiose

A helmintosporiose, como doença foliar do trigo, não é mundialmente considerada tão importante como é no Brasil (Mehta, 1981b). Por outro lado, a podridão comum de raízes, causada pelo mesmo fungo, causa danos consideráveis à cultura do trigo, em todo o mundo (Chinn, 1977; Reis \& Wünsche, 1984; Wildermuth \& McNamara, 1987). Talvez seja este o motivo pelo qual seja mais estudada que a mancha foliar de B. sorokiniana. Já a ferrugem da folha é uma doença amplamente estudada, conhecendo-se a interferência de vários fatores - temperatura, período de molhamento, luz, quantidade de inóculo inicial, raça do patógeno, genótipo do hospedeiro, estádio fenológico da planta sobre parâmetros monocíclicos, assim como sobre o desenvolvimento da doença em condições de campo (Yirgou \& Caldwell, 1963; Eyal \& Peterson, 1967; Yirgou \& Caldwell, 1968; Ohm \& Shaner, 1976; Kuhn et al., 1978; Eversmeyer et al., 1980; Tomerlin et al., 1983; Browder, 1985; Broers, 1989a; Broers, 1989b; Broers \& Wallenburg, 1989; Kaul \& Shaner, 1989; Subba Rao et al., 1989b; Denissen, 1991; Denissen, 1993; Statler \& Christianson, 1993; Vallavieille-Pope et al., 1995). Em função disto, foi feita a avaliação do efeito da temperatura e do período de molhamento nos parâmetros monocíclicos da helmintosporiose.

Observou-se o aumento da freqüência de infecção com o aumento da temperatura e do período de molhamento. Não foi possível o ajuste dos dados de $26^{\circ} \mathrm{C} / 16$ horas, $26^{\circ} \mathrm{C} / 24$ horas e $31^{\circ} \mathrm{C} / 24$ horas a modelos de regressão nãolinear, como foi feito para os demais tratamentos. Nestas combinações de temperatura e períodos de câmara úmida, houve um decréscimo do número de lesões por $\mathrm{cm}^{2}$, ao longo das avaliações, como conseqüência da sua coalescência.

$\mathrm{O}$ efeito conjunto da temperatura e do período de molhamento sobre a freqüência de infecção da helmintosporiose está apresentado na Figura 03. 
Os dados foram ajustados à função Beta-Richards, com coeficiente de determinação igual a 0,74 . A função descreve o aumento do número de lesões por $\mathrm{cm}^{2}$ com o aumento da temperatura e do periodo de molhamento. As temperaturas mínima e máxima para o desenvolvimento da doença (em número de lesões) foram estimadas em aproximadamente 6 e $37,2^{\circ} \mathrm{C}$, respectivamente, segundo o melhor ajuste dos dados.

A partir da média dos resultados de período de incubação da helmintosporiose nas diferentes temperaturas, foi feito o ajuste à função Beta generalizada, com coeficiente de determinação igual a 0,98 (Figura 04). Foram utilizados os dados médios de período de incubação, nas seis temperaturas analisadas, nos dois experimentos em condições de ambiente controlado $(6,11$, $16,21,26$ e $31^{\circ} \mathrm{C}$ ). $\mathrm{O}$ valor de 0,61 estimado pelo modelo para o parâmetro $B_{2}$ não tem significado biológico, mas corresponde ao melhor ajuste obtido para os dados. Ressalta-se, ainda, que esta equação deve ser usada dentro dos limites de temperatura considerados $\left(6 \mathrm{e} 31^{\circ} \mathrm{C}\right)$, os quais, praticamente, correspondem à faixa de temperatura na qual a doença se desenvolve. Observa-se a diminuição do período de incubação com o aumento da temperatura. Em outras palavras, quanto maior for a temperatura, mais rapidamente se desenvolverão os sintomas da helmintosporiose. Apesar do período de incubação ser curto, Shaner (1981) comenta que os períodos latentes de doenças como a helmintosporiose são geralmente longos e que os conídios não são formados até que a lesão necrótica seja extensa ou até que a folha esteja morta.

Verificou-se, ainda, que com o aumento do período de câmara úmida, houve a diminuição do período de incubação. Morton (1962) em folhas destacadas de cevada, também observou a diminuição do período de incubação da helmintosporiose com o aumento da temperatura e da umidade. Biggs \& Northover (1988), estudando o efeito da temperatura e do molhamento foliar no desenvolvimento de Monilinia fructicola, supõem que a diminuição do período de 


$$
\begin{gathered}
\mathrm{FI}=0,32 *((\mathrm{~T}-6) * * 0,57) *((37,20-\mathrm{T}) * *(-0,12)) *\left(1-(2,21) * \exp (-0,39)^{*} \mathrm{M}\right) * *(1,75) \\
\mathrm{R}^{2}=0,74
\end{gathered}
$$

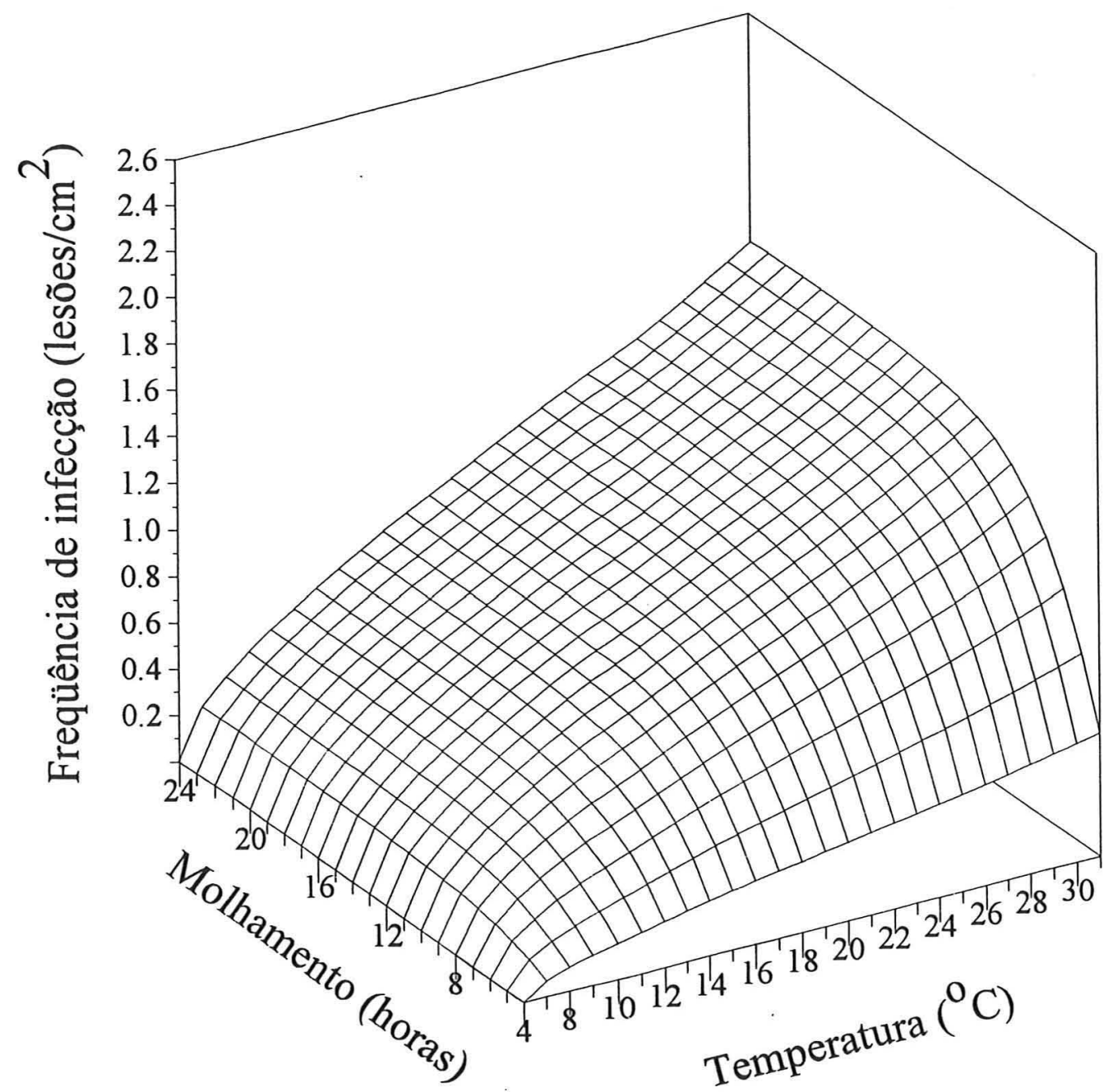

Figura 03. Efeito da temperatura (T) e do período de molhamento (M) sobre a freqüência de infecção (FI) da helmintosporiose, em plantas adultas de trigo do cultivar IAC-24. Média de três repetições. 


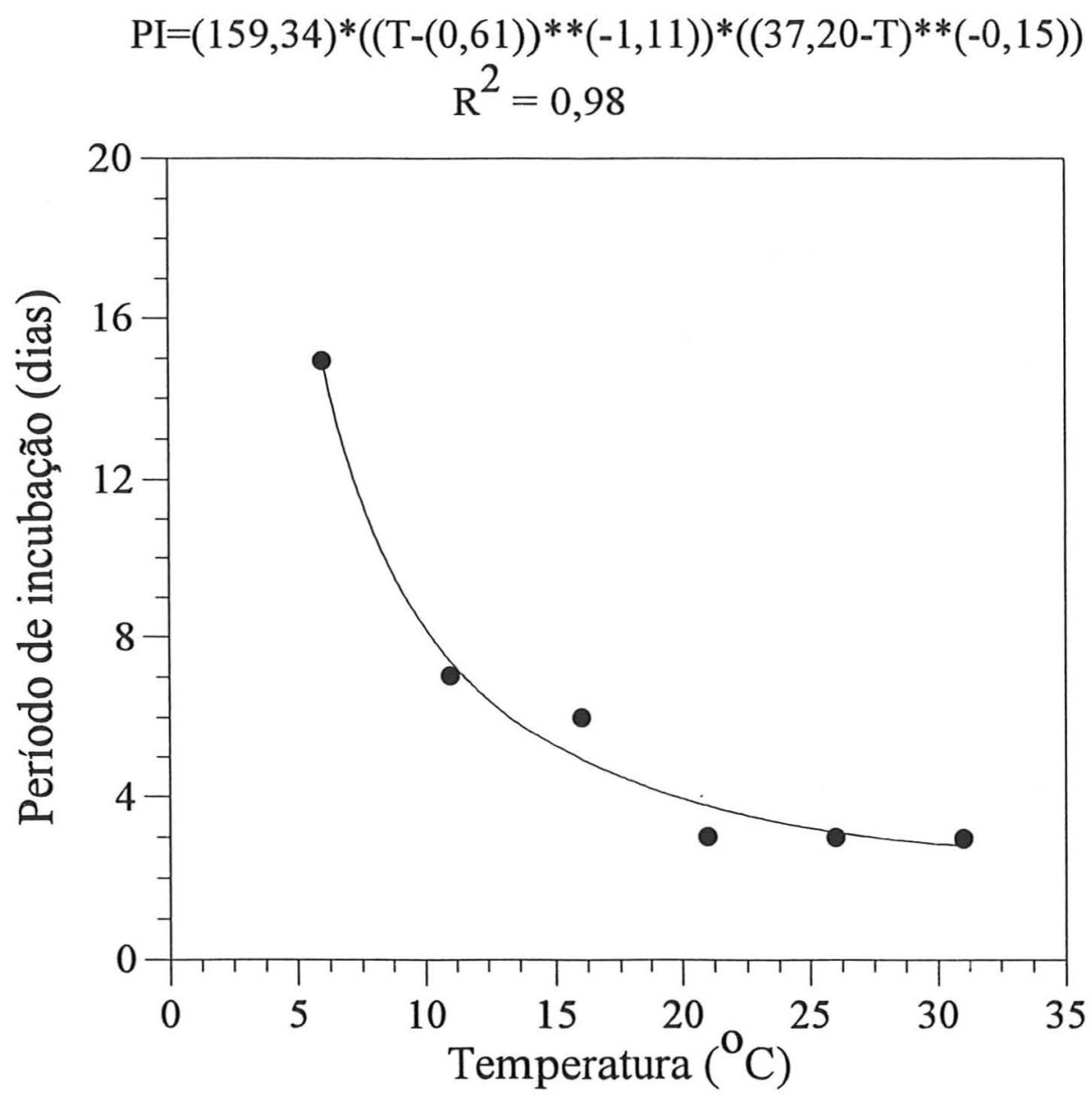

Figura 04. Efeito da temperatura (T) sobre o período de incubação (PI) da helmintosporiose, em plantas do cultivar de trigo IAC-24.

incubação com o aumento do molhamento, deve-se à maior porcentagem de penetração dos esporos, em função de talos maiores e mais vigorosos. Jacome \& Schuh (1992), por outro lado, acreditam que o atraso no aparecimento dos sintomas da Sigatoka negra em folhas de bananeira, com períodos de molhamento menores, esteja relacionado ao requerimento de um período mais longo de absorção de água para a germinação dos conídios.

À medida que houve o aumento da temperatura e da umidade, verificou-se o aumento da severidade da helmintosporiose, cujo valor máximo foi 
observado ao redor dos $26^{\circ} \mathrm{C}$, como mostra a Figura 05 . Nesta, são apresentados os dados de severidade ajustados à função Beta-Richards, com coeficiente de determinação igual a 0,87 .

Não são comuns estudos da influência da temperatura e da umidade sobre a mancha foliar de B. sorokiniana, em plantas de trigo. Ao se considerar o efeito da temperatura isoladamente, vários trabalhos indicam o maior e mais rápido desenvolvimento da helmintosporiose, quanto maior a temperatura (Clark \& Dickson, 1958; Wood, 1962; Luz \& Bergstrom, 1986). Analisando-se os parâmetros freqüência de infecção e período de incubação, o mesmo comportamento é observado. Porém, a maior severidade foi observada sob $26^{\circ} \mathrm{C}$, a qual foi seguida, em ordem decrescente de severidade, pelas temperaturas de 31 , 16,11 e $6^{\circ} \mathrm{C}$, respectivamente. A severidade é função tanto da freqüência de infeç̧ão quanto do tamanho das lesões. Assim, conclui-se que o crescimento da lesão é maior sob a temperatura de $26^{\circ} \mathrm{C}$ que sob a de $31^{\circ} \mathrm{C}$, apesar desta última apresentar um maior número de lesões por $\mathrm{cm}^{2}$.

Luz (1982) estudou o efeito de diferentes períodos de umidade após a inoculação na reação de cultivares de trigo à helmintosporiose. Foram analisados os períodos de $6,12,18,24,30,36,42,48$ e 54 horas de câmara úmida. Observou-se o aumento da severidade da doença com o aumento do período de molhamento. Segundo este autor, o período mínimo requerido para a infecção foi de 6 horas. Nema \& Joshi $(1973)^{5}$, citados por Luz (1982), afirmavam que $B$. sorokiniana requereria um período mínimo de 24 horas para causar infecção em plantas de trigo. No presente trabalho, não foi possível a determinação do período mínimo de umidade para a infecção por B. sorokiniana, mas com 4 horas de molhamento, ainda houve o desenvolvimento de lesões pelo fungo.

\footnotetext{
${ }^{5}$ NEMA, K.G.; JOSHI, L.M. Spot-blotch disease of wheat in relation to host age, temperature and moisture. Indian Phytopathology, v.26, n. 1, p. 41-8, 1973.
} 


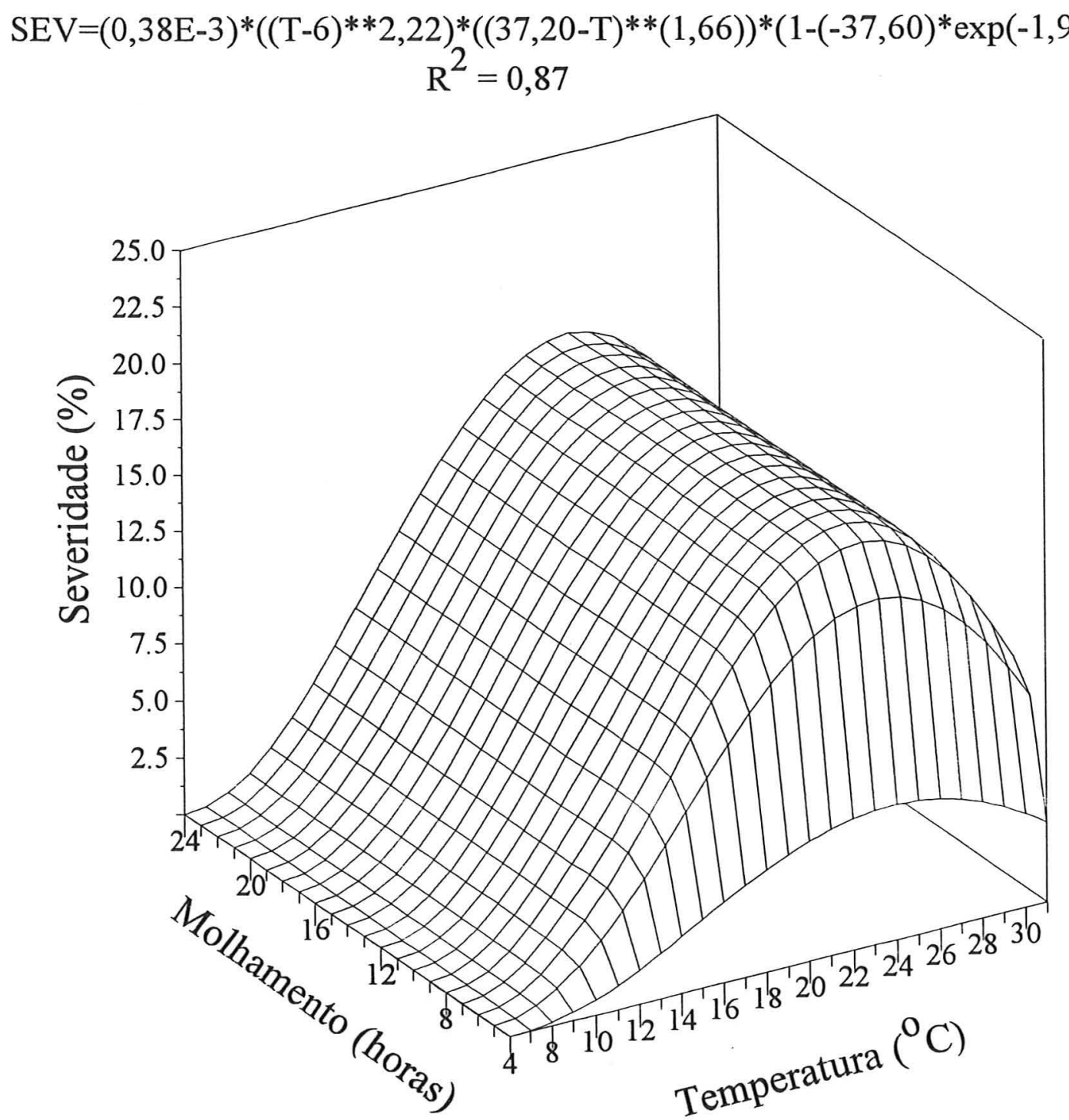

Figura 05. Efeito da temperatura (T) e do período de molhamento (M) sobre a severidade (SEV) da helmintosporiose, em plantas adultas de trigo do cultivar IAC-24. Média de três repetições. 
Khanna \& Shukla $(1981)^{6}$, citados por Sentelhas (1992), afirmam que há uma interdependência entre os fatores temperatura e umidade. Eles constataram que o período de molhamento e a umidade só começam a ter efeito sobre a doença quando as temperaturas são favoráveis ao processo. Fernandes \& Hendrix (1986), trabalhando com Septoria nodorum em trigo, observaram que tanto a temperatura quanto o molhamento foliar são fatores de influência significativa na doença. O número de lesões por $\mathrm{cm}^{2}$ é mais influenciado pela umidade, mas quanto à severidade, a interação temperatura-molhamento é muito importante. Como B. sorokiniana, S. nodorum foi favorecido por altas temperaturas e longos períodos de molhamento e foi constatado também que o período de incubação é maior nas temperaturas mais baixas.

Hosford Jr. et al. (1987) estudaram a interação do período de molhamento com a temperatura sobre a infecção e o desenvolvimento de Drechslera tritici-repentis em trigo. A interação dos dois fatores foi significativa. Sob $20^{\circ} \mathrm{C}$, a porcentagem de colonização aumentou significativamente entre 6 e 12 horas de molhamento, mas não aumentou com 24 horas e decresceu significativamente com 48 e 66 horas de molhamento.

Morton (1962) analisou a influência da temperatura, da umidade e da concentração de esporos no desenvolvimento de B. sorokiniana em folhas destacadas de cevada. A temperatura de $30^{\circ} \mathrm{C}$ foi mais favorável ao desenvolvimento de sintomas do que 20 e $15^{\circ} \mathrm{C}$, inclusive não houve reprodução de sintomas sob $15^{\circ} \mathrm{C}$ com as mais altas umidades relativas. Ledingham (1970), por outro lado, estudando a sobrevivência de conídios deste fungo sob diferentes umidades relativas, constatou que quanto maior a umidade relativa, menor a longevidade dos esporos, e que este efeito era tanto maior quanto maior a temperatura. Observa-se, assim, uma certa contradição sobre os efeitos da

\footnotetext{
${ }^{6}$ KHANNA, B.M.; SHUKLA, T.N. Epidemiological studies on leaf blight of wheat caused by Helminthosporium spp. Indian Journal of Mycology and Plant Pathology, v.11, n.1, p. 21-9, 1981.
} 
interação temperatura-molhamento sobre B. sorokiniana. Ledingham (1970) explica que a redução da longevidade com o aumento da temperatura, provavelmente, deve-se ao aumento da respiração dos conídios em níveis mais altos de umidade relativa.

Vallavieille-Pope et al. (1995) realizaram um estudo comparativo entre a ferrugem da folha e a ferrugem estriada em plântulas de trigo, considerando-se os efeitos da temperatura e de interrupções no período de molhamento. A freqüência de infecção de $P$. recondita, sob condições ótimas, foi cerca de 12 vezes maior que a de $P$. striiformis. Além do que, a primeira apresenta uma faixa de temperatura ampla para o seu desenvolvimento. $P$. striiformis, por outro lado, como demostrado por Emge et al. (1975), apresenta o crescimento de suas lesões. Esta característica sendo menos dependente de condições climáticas (Zadoks, 1984) garante o sucesso de suas epidemias (Lannou et al., 1994b).

Considerando os patossistemas em estudo: B. sorokiniana - trigo e P. recondita - trigo, diferenças podem ser confirmadas. Nos estudos monocíclicos realizados, a menor freqüência de infecção da ferrugem da folha foi $39 \%$ mais alta que a maior freqüência de infecção da helmintosporiose (Tabela 03).

É evidente a diferença entre os dois patógenos quanto às temperaturas mais favoráveis para o desenvolvimento das respectivas doenças. A helmintosporiose é favorecida por temperaturas mais altas, enquanto a ferrugem, por temperaturas mais amenas. Ao se comparar a severidade das doenças, sob condições favoráveis, a helmintosporiose supera a ferrugem. Uma vez que a severidade é função tanto do número quanto do tamanho das lesões, a maior área coberta por sintomas da helmintosporiose é explicada pelo crescimento de suas lesões. Vitti (1993) também constatou diferenças epidemiológicas entre dois patógenos de uma cultura tipicamente tropical. O autor comparou o comportamento de Exserohilum turcicum e Puccinia sorghi, em plantas de milho, 
em condições de ambiente controlado e de campo. Nos experimentos realizados em câmaras de crescimento, $P$. sorghi apresentou maior freqüência de infecção e por outro lado, E. turcicum, a maior velocidade de crescimento das lesões.

Pela análise dos dados de helmintosporiose, pode-se supor que o período mínimo de umidade requerido pelo fungo para causar infecção é menor que 4 horas. Duczek \& Wildermuth (1992) observaram que a esporulação de $B$. sorokiniana é favorecida por condições mornas e úmidas. A produção de conídios foi diminuída com a redução da temperatura. Além disso, os autores verificaram que ciclos de umidade e seca provavelmente aumentariam a esporulação do fungo. Através de estudo sobre a influência de curtos períodos de umidade no desenvolvimento de doenças foliares, Bashi \& Rotem (1974) verificaram exemplos em que níveis similares de infecção foram obtidos com e sem a interrupção do período de molhamento. Ao estudarem a ferrugem da folha do trigo, Vallavieille-Pope et al. (1995) observaram que o período mínimo de molhamento requerido pelo fungo para causar infecção foi de 4 horas, sob temperatura ótima para o desenvolvimento da doença. E, segundo Torres et al. (1995), sob $26^{\circ} \mathrm{C}$ e 4 horas de molhamento foliar, temperatura já considerada como desfavorável para a ferrugem, não houve a produção de pústulas de $P$. recondita.

Os resultados obtidos em câmara de crescimento, juntamente com as informações da literatura, confirmam a hipótese do presente trabalho. A ferrugem, causada por $P$. recondita, estaria mais adaptada às condições de clima de regiões temperadas, onde predominam, durante a estação de cultivo, temperaturas amenas e abundância de orvalho. B. sorokiniana, agente causal da helmintosporiose, apresentaria uma maior vulnerabilidade às baixas temperaturas e maior adaptabilidade a condições de estresse hídrico. Estas duas características indicam a maior flexibilidade deste patógeno em suportar a falta de umidade, fato comum nos trópicos, e a restrição do seu desenvolvimento a uma amplitude 
menor de temperatura. E, buscando vencer as adversidades impostas pelo clima, B. sorokiniana lança mão do aumento do tamanho das lesões, além do aumento do número de lesões, para promover o progresso da epidemia.

Uma vez comprovada, na quantificação de parâmetros monocíclicos, a importância do crescimento da lesão para o desenvolvimento da doença, Lannou et al. (1994b) ressaltam a necessidade da realização de estudos policíclicos comparativos. Através deles, poderá ser evidenciado, ou não, o papel decisivo do crescimento das lesões no desenvolvimento de epidemias, a nível de campo, para doenças típicas de clima tropical.

\subsection{Experimentos em condições de campo}

As Figuras 06 e 07 trazem as curvas de progresso das doenças, em número de lesões por $\mathrm{cm}^{2}$ e em severidade (porcentagem), em plantas marcadas, no ano de 1994. As plantas foram avaliadas nos seguintes estádios fenológicos: 45-49 (bainha toda dilatada - primeiras aristas visíveis); 54-56 (1/2 da inflorescência emergida - 3/4 da inflorescência emergida); 58 (emergência completa da inflorescência); e 60 (início da abertura das anteras), da escala de Zadoks et al. (1974). No ano de 1994, a incidência da helmintosporiose foi baixa. Pôde-se, contudo, verificar que houve maior desenvolvimento da helmintosporiose no cultivar IAC-24 (Figura 06), enquanto que a ferrugem se desenvolveu melhor no BR-34 (Figura 07).

No cultivar IAC-24 (Figura 06), a ferrugem supera a helmintosporiose quanto ao número de lesões por $\mathrm{cm}^{2}$, em cerca de duas vezes. Ao se considerar a severidade, é a helmintosporiose que apresenta dezesseis vezes a porcentagem de área foliar coberta por pústulas de $P$. recondita. Isto ocorre em função do crescimento das lesões de $B$. sorokiniana. Com o aumento do tamanho 
das lesões, há a conquista de maior área foliar pelo patógeno, mesmo que com menor número de lesões por $\mathrm{cm}^{2}$.

No cultivar BR-34 (Figura 07), o desenvolvimento da helmintosporiose foi reduzido, ao contrário do que ocorreu com a ferrugem da folha. Foram constatados sintomas da helmintosporiose somente em duas das quatro parcelas deste cultivar avaliadas. A ferrugem, por sua vez, apresentou um aumento progressivo do número de lesões por $\mathrm{cm}^{2}$, que resultou em valores médios de severidade de $40 \%$. Neste cultivar, a helmintosporiose, mesmo com o característico crescimento de suas lesões, foi superada pela ferrugem, também quanto à severidade.

Os dados de amostragem (Figura 08) somente vêm reforçar os dados obtidos com as plantas marcadas, no ano de 1994. Em função disso, decidiu-se pela não realização de amostragens, no ano de 1995. As plantas das quais as folhas foram amostradas encontravam-se nos seguintes estádios fenológicos: 39 (aparecimento da lígula e aurícula da folha bandeira); 45-49 (bainha toda dilatada - primeiras aristas visíveis); $54-56$ (1/2 da inflorescência emergida - 3/4 da inflorescência emergida); 58 (emergência completa da inflorescência); e 60 (início da abertura das anteras), da escala de Zadoks et al. (1974). A helmintosporiose ocorreu em baixa intensidade no cultivar IAC-24 e não houve o aparecimento de manchas de B. sorokiniana sobre o cultivar BR-34. $\mathrm{E}$ ao se considerar as avaliações da ferrugem da folha, nota-se o maior desenvolvimento de sintomas sobre o cultivar BR-34 (Figura 08 - B, D) que sobre o IAC-24 (Figura 08 - A, C). As folhas amostradas sistematicamente indicam maior número de lesões de ferrugem por $\mathrm{cm}^{2}$, determinando maior severidade desta doença em relação à helmintosporiose, em ambos os cultivares.

Nas Figuras 09 e 10 são representadas as curvas de progresso das doenças, em número de lesões por $\mathrm{cm}^{2}$ e em severidade (porcentagem), em plantas marcadas, no ano de 1995. As plantas foram avaliadas nos seguintes 

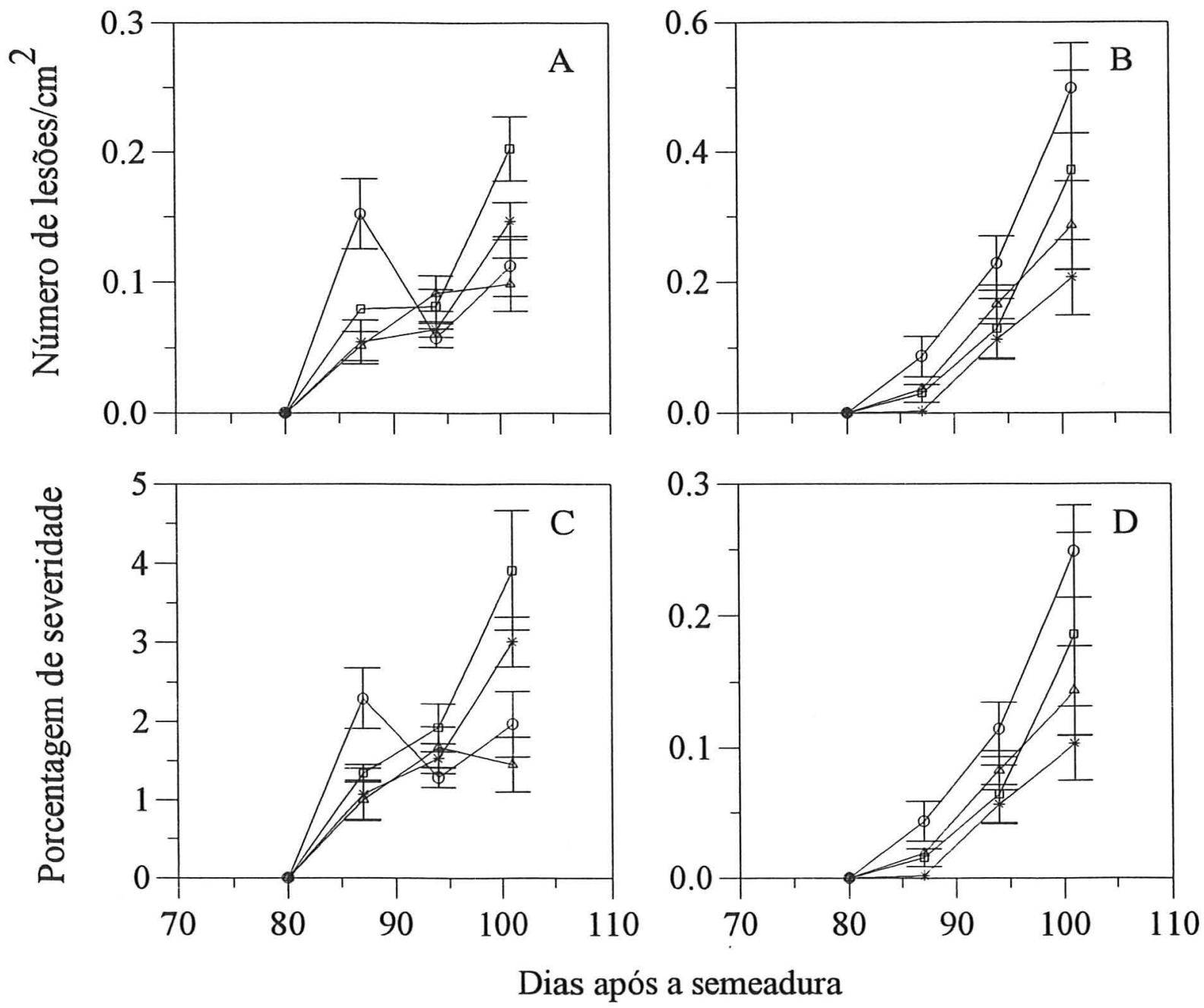

Figura 06. Médias e erros padrão dos dados de número de lesões por $\mathrm{cm}^{2}(\mathrm{~A}, \mathrm{~B}) \mathrm{e}$ porcentagem de severidade $(C, D)$ da helmintosporiose $(A, C)$ e da ferrugem da folha $(B, D)$, em plantas marcadas do cultivar de trigo IAC-24, no ano de 1994. Cada ponto representa a média de dez plantas por parcela. 

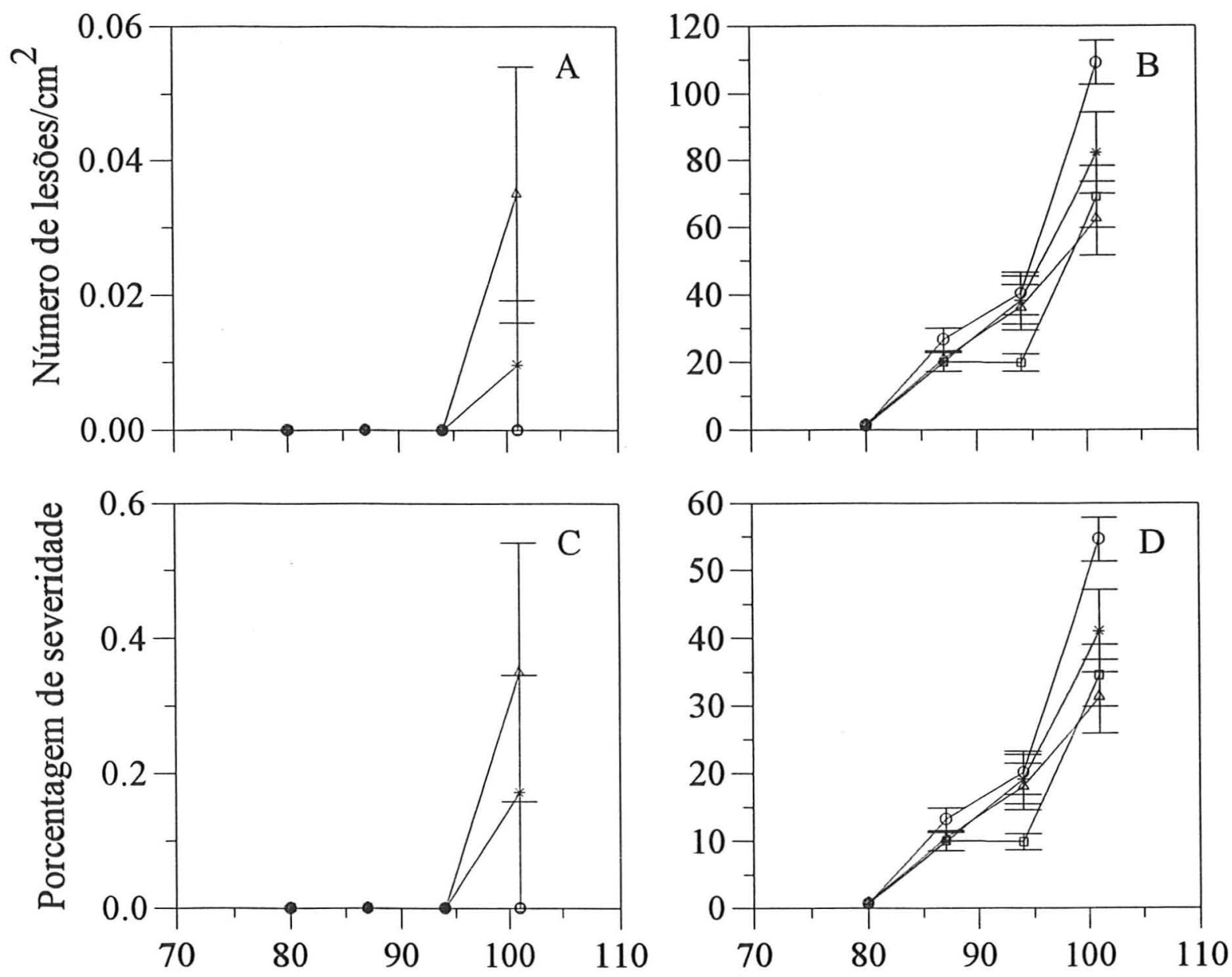

Dias após a semeadura

Figura 07. Médias e erros padrão dos dados de número de lesões por $\mathrm{cm}^{2}(\mathrm{~A}, \mathrm{~B}) \mathrm{e}$ porcentagem de severidade $(C, D)$ da helmintosporiose $(A, C)$ e da ferrugem da folha (B, D), em plantas marcadas do cultivar de trigo BR34, no ano de 1994. Cada ponto representa a média de dez plantas por parcela. 
estádios fenológicos: 54-58 (1/2 da inflorescência emergida - emergência completa da inflorescência); 58 (emergência completa da inflorescência); 60 (início de abertura das anteras); e 68 (florescimento pleno), da escala de Zadoks et al. (1974). No ano de 1995, no cultivar IAC-24 (Figura 09), houve o aumento na intensidade de ambas as doenças mas, como no ano anterior, houve maior desenvolvimento da helmintosporiose que da ferrugem. Quanto ao cultivar BR-34 (Figura 10), não houve o aparecimento de sintomas da helmintosporiose e a ferrugem ocorreu em nível de intensidade semelhante à de 1994.

No cultivar IAC-24 (Figura 09), a helmintosporiose excede a ferrugem tanto em número de lesões por $\mathrm{cm}^{2}$ quanto em severidade. Porém, ao se considerar a relação entre número de lesões e severidade de cada uma das doenças, visualiza-se que a helmintosporiose, com o dobro do número de lesões de ferrugem, atinge 50 vezes a sua severidade. E ainda, comparando-se os resultados da helmintosporiose no cultivar IAC-24 (Figura 09 - A, C) com os de ferrugem no cultivar BR-34 (Figura 10 - A, B), diferenças são constatadas. A helmintosporiose teve uma média de cinco lesões por $\mathrm{cm}^{2}$ e a ferrugem, setenta e cinco, e as severidades foram respectivamente 60 e $40 \%$. A maior severidade da helmintosporiose, com menor número de lesões por $\mathrm{cm}^{2}$, é explicada pelo crescimento das suas lesões.

Não foi possível o ajuste dos dados a nenhum dos modelos de regressão não-linear testados. Assim, foi calculada a área sob a curva de progresso da doença (AUDPC) para cada uma das doenças e para cada um dos cultivares, nos anos de 1994 (Tabelas 06 e 07) e 1995 (Tabelas 08 e 09). A AUDPC foi calculada com as curvas de progresso de doença expressas em número de lesões por $\mathrm{cm}^{2}$ (Tabelas 06 e 08) e em severidade (Tabelas 07 e 09). Segundo Campbell \& Madden (1990), a AUDPC pode ser usada para se descrever epidemias, em situações em que nenhum dos modelos de crescimento considerados forem apropriados para este fim. À AUDPC são incorporadas 

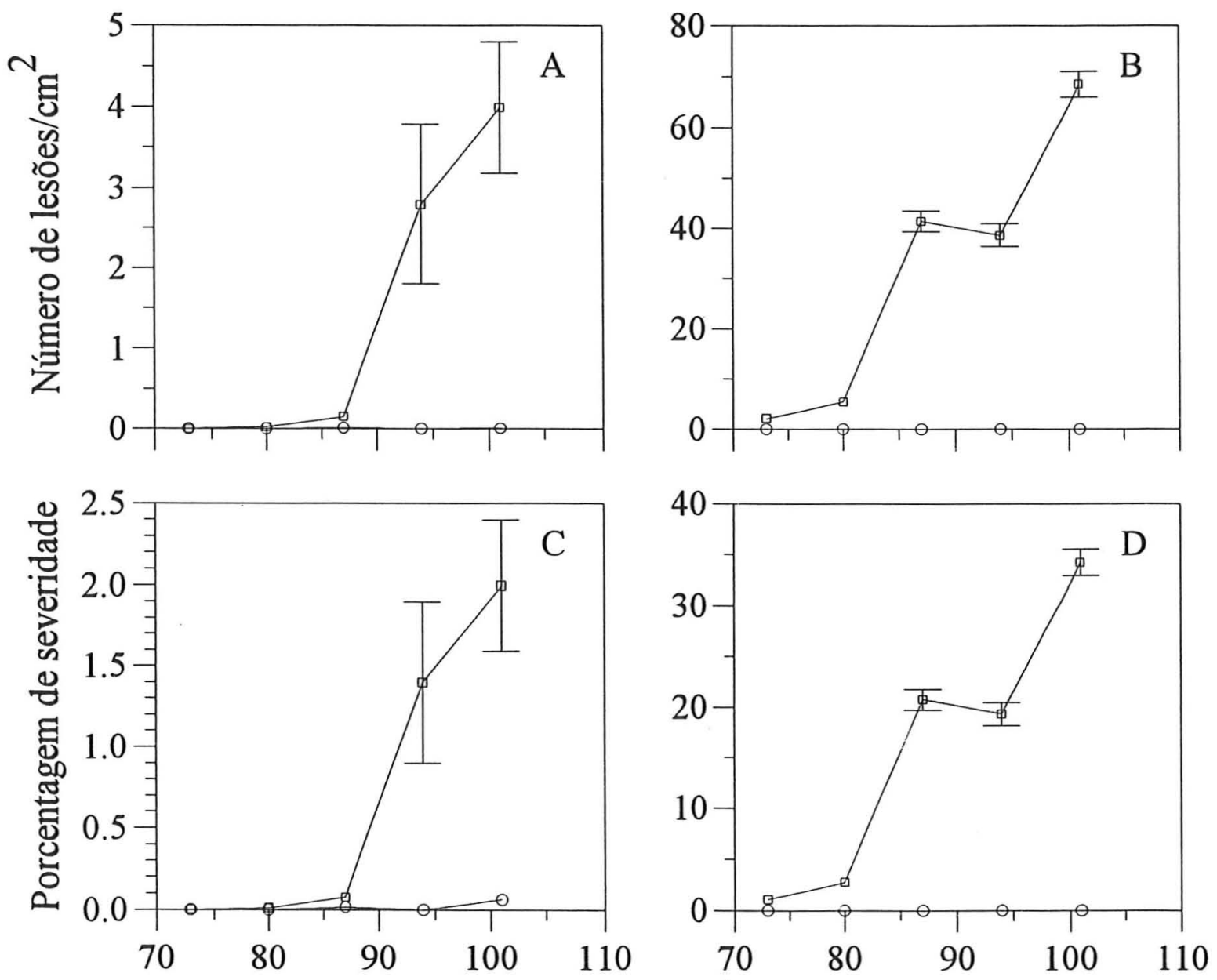

Dias após a semeadura

\section{$\Phi$ Helmintosporiose 五 Ferrugem}

Figura 08. Médias e erros padrão dos dados de número de lesões por $\mathrm{cm}^{2}$ (A, B) e porcentagem de severidade $(C, D)$ da helmintosporiose e da ferrugem da folha, em folhas dos cultivares de trigo IAC-24 (A, C) e BR-34 (B, D), amostradas no ano de 1994. Cada ponto representa a média de cinqüenta a sessenta folhas. 

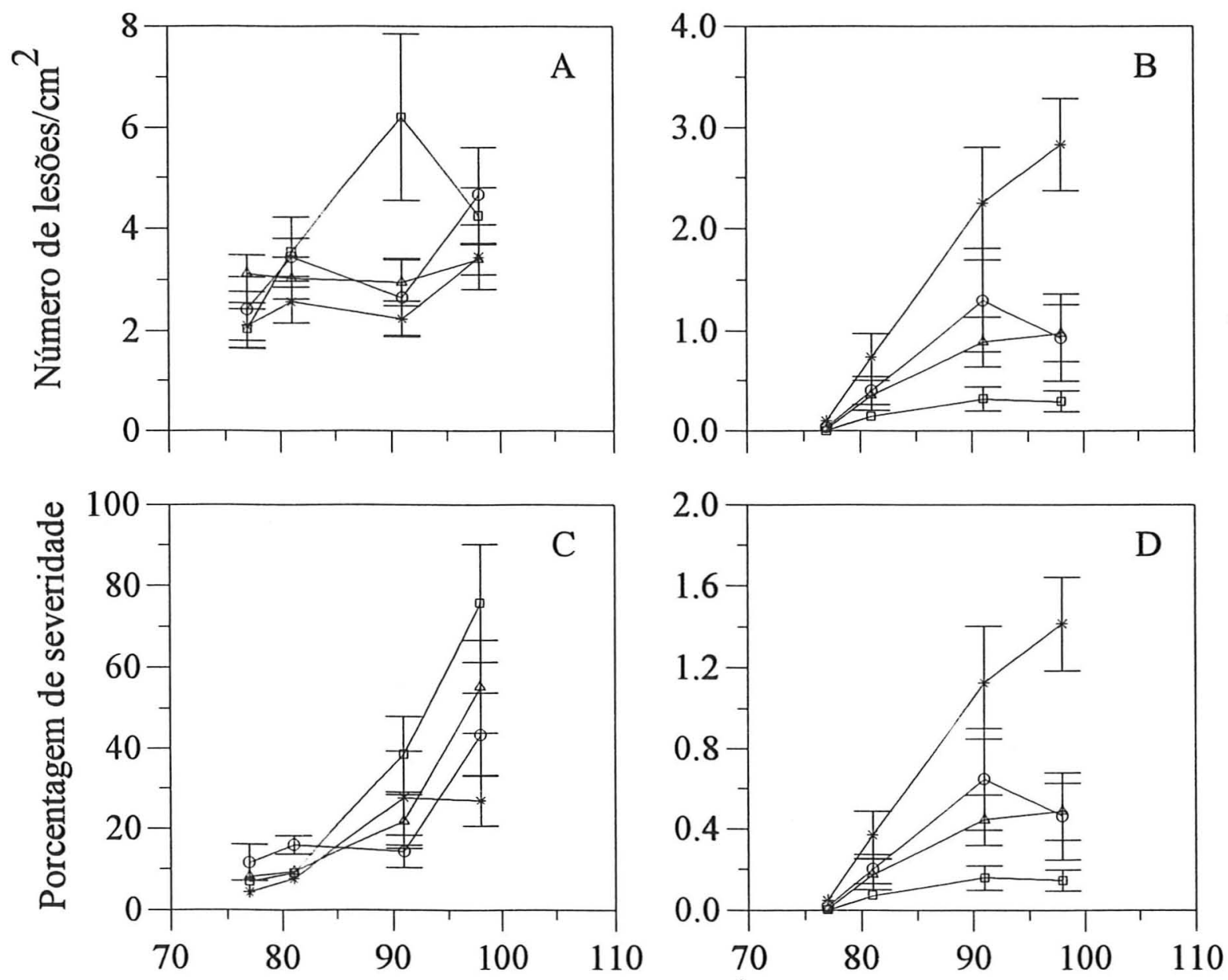

Dias após a semeadura

Figura 09. Médias e erros padrão dos dados de número de lesões por $\mathrm{cm}^{2}(\mathrm{~A}, \mathrm{~B}) \mathrm{e}$ porcentagem de severidade $(C, D)$ da helmintosporiose $(A, C)$ e da ferrugem da folha (B, D), em plantas marcadas do cultivar de trigo IAC-24, no ano de 1995. Cada ponto representa a média de dez plantas por parcela. 

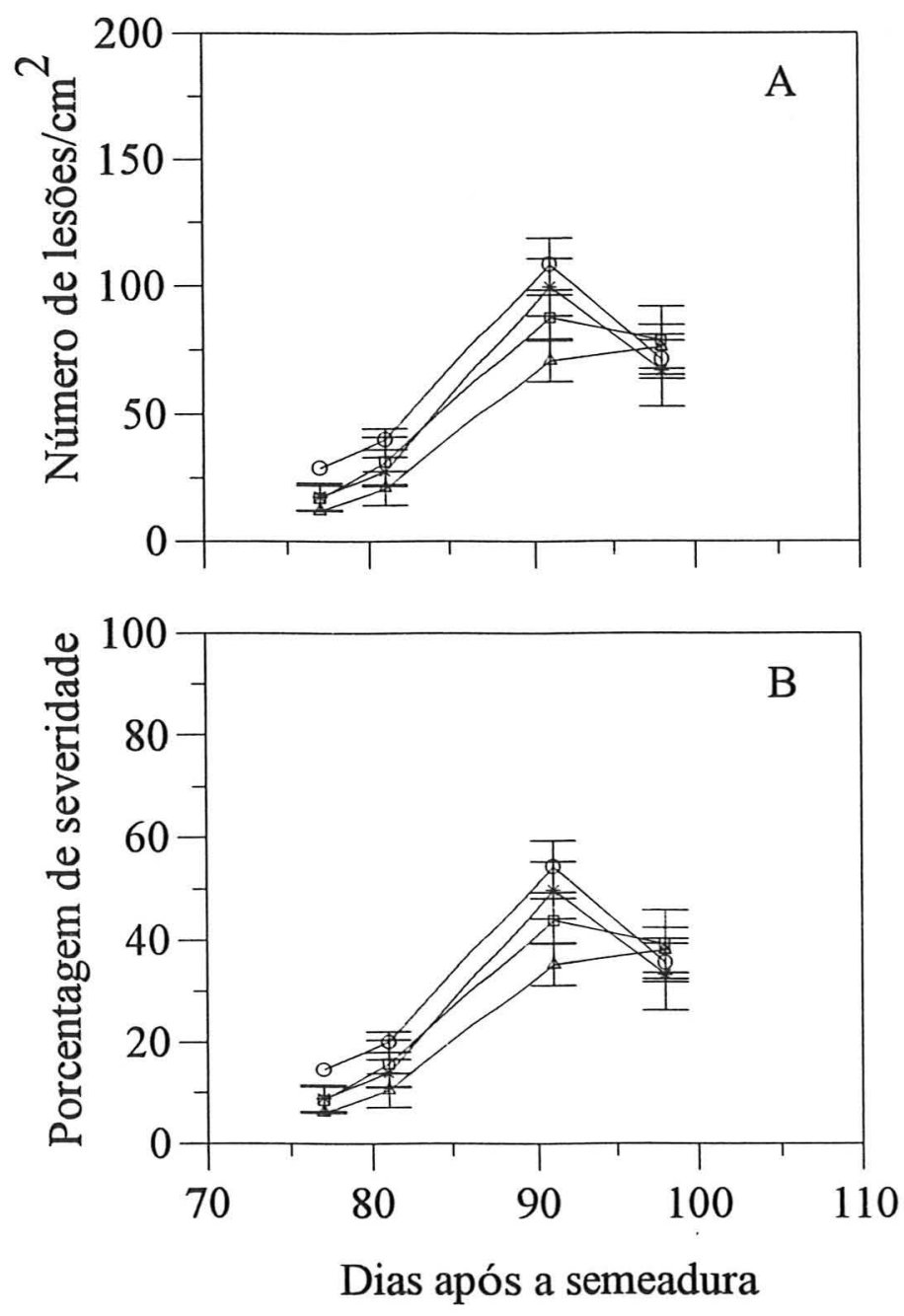

Figura 10. Médias e erros padrão dos dados de número de lesões por $\mathrm{cm}^{2}$ (A) e porcentagem de severidade (B) da ferrugem da folha, em plantas marcadas do cultivar de trigo BR-34, no ano de 1995. Cada ponto representa a média de dez plantas por parcela. 
variações quanto ao tempo de início da doença, quanto à taxa de progresso da doença e quanto à quantidade final da doença.

Considerando a AUDPC obtida com a curva de doença expressa em número de lesões por $\mathrm{cm}^{2}$, em 1994 (Tabela 06), verifica-se que em ambos os cultivares, a ferrugem supera a helmintosporiose, em valores significativamente diferentes. Avaliando-se a severidade (Tabela 07), as AUDPC da helmintosporiose e da ferrugem da folha diferiram estatisticamente entre si nos dois cultivares. No cultivar IAC-24, a helmintosporiose supera a ferrugem, e a relação inversa é verificada no BR-34. Independentemente de como eram expressas as AUDPC, constatou-se a maior intensidade da ferrugem sobre o cultivar BR 34, enquanto que a helmintosporiose desenvolveu-se melhor sobre o IAC 24.

Os dados do ano de 1995 (Tabelas 08 e 09) apresentam o aumento na intensidade das doenças em relação ao ano de 1994. No cultivar BR-34, a ferrugem da folha ocorreu em tão alta intensidade que não houve 0 desenvolvimento da helmintosporiose. Esta doença diferiu da ferrugem, nos dois cultivares estudados, e considerando cada uma delas separadamente, os cultivares também diferiram entre si, no que se refere ao número de lesões e à severidade. A helmintosporiose ocorreu em maior intensidade sobre o cultivar IAC-24, superando a ferrugem, tanto em número de lesões como em severidade.

Os Apêndices 01 e 02, nos quais estão apresentados os dados climáticos dos anos agrícolas considerados, indicam que no ano de 1995, as temperaturas eram, em média, mais altas que as do ano de 1994. Neste, houve quedas de temperatura, com a temperatura mínima atingindo valores abaixo de zero graus centígrados, nos meses de junho e julho, e próximo de zero, no início do mês de agosto. Além disso, o ano de 1994 foi menos chuvoso e os valores médios da umidade relativa do ar foram, geralmente, mais baixos que os do ano 
Tabela 06. Área sob as curvas de progresso das doenças (AUDPC) helmintosporiose e ferrugem da folha, em condições naturais de infecção, em plantas de trigo dos cultivares IAC-24 e BR-34, no ano de 1994. Valores obtidos das curvas de progresso das doenças em lesões por $\mathrm{cm}^{2}$. Média de quatro repetições.

\begin{tabular}{lrrrr}
\hline \multicolumn{1}{c}{ AUDPC } & \multicolumn{3}{c}{ Cultivar } \\
& IAC 24 & BR 34 \\
\hline Helmintosporiose & 2,36 & aB & 0,04 & bB \\
Ferrugem & 13,42 & bA & 675,22 & aA
\end{tabular}

Letras diferentes, minúsculas na linha e maiúsculas na coluna, diferem estatisticamente entre si pelo teste de Tukey a $5 \%$.

Tabela 07. Área sob as curvas de progresso das doenças (AUDPC) helmintosporiose e ferrugem da folha, em condições naturais de infecção, em plantas de trigo dos cultivares IAC-24 e BR-34, no ano de 1994. Valores obtidos das curvas de progresso das doenças em severidade. Média de quatro repetições.

\begin{tabular}{lrrrr}
\hline \multicolumn{1}{c}{ AUDPC } & \multicolumn{4}{c}{ Cultivar } \\
& IAC 24 & BR 34 \\
\hline Helmintosporiose & 44,46 & aA & 0,46 & bB \\
Ferrugem & 6,71 & bB & 337,61 & aA \\
\hline
\end{tabular}

Letras diferentes, minúsculas na linha e maiúsculas na coluna, diferem estatisticamente entre si pelo teste de Tukey a $5 \%$. 
Tabela 08. Área sob as curvas de progresso das doenças (AUDPC) helmintosporiose e ferrugem da folha, em condições naturais de infecção, em plantas de trigo dos cultivares IAC-24 e BR-34, no ano de 1995. Valores obtidos das curvas de progresso das doenças em lesões por $\mathrm{cm}^{2}$. Média de quatro repetições.

\begin{tabular}{lrrrr}
\hline \multicolumn{1}{c}{ AUDPC } & \multicolumn{3}{c}{ Cultivar } \\
& IAC 24 & \multicolumn{2}{c}{ BR 34 } \\
\hline Helmintosporiose & 70,42 & aA & 0 & bB \\
Ferrugem & 17,41 & bB & 1283,27 & aA \\
\hline
\end{tabular}

Letras diferentes, minúsculas na linha e maiúsculas na coluna, diferem estatisticamente entre si pelo teste de Tukey a $5 \%$.

Tabela 09. Área sob as curvas de progresso das doenças (AUDPC) helmintosporiose e ferrugem da folha, em condições naturais de infecção, em plantas de trigo dos cultivares IAC-24 e BR-34, no ano de 1995. Valores obtidos das curvas de progresso das doenças em severidade. Média de quatro repetições.

\begin{tabular}{lrccc}
\hline \multicolumn{1}{c}{ AUDPC } & \multicolumn{3}{c}{ Cultivar } \\
& IAC 24 & \multicolumn{2}{c}{ BR 34 } \\
\hline Helmintosporiose & 482,26 & aA & 0 & bB \\
Ferrugem & 8,70 & bB & 641,64 & aA \\
\hline
\end{tabular}

Letras diferentes, minúsculas na linha e maiúsculas na coluna, diferem estatisticamente entre si pelo teste de Tukey a $5 \%$. 
de 1995. A maior umidade relativa do ar está correlacionada com maior período de molhamento, como verificou Sentelhas (1992). Estudando a influência de condições microclimáticas sobre a ocorrência de helmintosporiose e de oídio na cultura do trigo, este autor obteve uma correlação de 0,94 entre o número de horas com umidade relativa igual ou superior a $90 \%$, como variável independente, e a duração do período de molhamento, como variável dependente. Temperaturas mais estáveis e maior umidade relativa é que propiciaram o aumento na intensidade das doenças no ano de 1995, em relação a 1994. Segundo Burleigh et al. (1972a), um dia tem favorabilidade 1 (máxima) para a ferrugem da folha do trigo quando a temperatura mínima é igual ou superior a $4,4^{\circ} \mathrm{C}$, com quatro horas de molhamento, e ao menos com a coleta de um uredósporo por $\mathrm{cm}^{2}$. De acordo com Couture \& Sutton (1978), o progresso da helmintosporiose está relacionado a períodos quentes e úmidos com chuvas, e o abaixamento da temperatura é o principal fator limitante da produção de esporos de B. sorokiniana.

Com respeito à esporulação, Mehta \& Zadoks (1970) verificaram que a alta densidade de pústulas de $P$. recondita causa a redução do período latente e alta taxa de abertura de novas pústulas. Este fungo apresentou um longo período infeccioso, o que poderia servir como estratégia de sobrevivência quando fossem baixas as chances de causar infecções. A produção de esporos juntamente com o período latente são a base para explicar o aumento da intensidade da doença em função do tempo, sendo $P$. recondita um patógeno tipicamente temperado (Bergamin Filho \& Amorim, 1996). Comparativamente, a capacidade de esporulação e o período infeccioso de $B$. sorokiniana são menores que os de $P$. recondita (Mehta, 1981b). Por outro lado, este patógeno apresenta a característica de aumentar o tamanho de suas lesões, característica esta que exerceria papel importante na epidemiologia tropical (Bergamin Filho \& Amorim, 1996). B. sorokiniana apresenta lesões grandes e o tecido foliar ainda não invadido precisa morrer antes que o fungo possa produzir conídios (Shaner, 1981). Segundo 
Couture \& Sutton (1978), quanto maior a área das lesões do patógeno, maior a área potencial para esporulação quando as condições de umidade se mostrarem favoráveis. Porém, Shaner (1981) afirma que a infecção secundária deste fungo é mais complicada, pois ele não produz conídios em abundância durante a estação de cultivo. Já quanto à $P$. recondita, comumente são observados, em condições de campo, um ou dois anéis de pústulas secundárias (Mehta \& Zadoks, 1970).

De modo geral, houve o aumento das doenças ao longo das avaliações. Segundo Nutter Jr. et al. (1985), a helmintosporiose provoca a redução no rendimento da cevada principalmente devido à redução no peso dos grãos, e este efeito foi maior nos estádios fenológicos 36 e 55, que no 70, da escala de Zadoks et al. (1974). Os autores observaram, ainda, maior severidade da doença na folha F-2, que sobre a F-1, cuja severidade, por sua vez, foi maior que a da folha bandeira. Esta informação explica o porquê de haver numa das parcelas do cultivar IAC-24, a redução na intensidade da mancha de $B$. sorokiniana na última avaliação (Figura 06 - A, C). Foram considerados os dados médios das três folhas superiores por planta, e nas duas últimas avaliações, as folhas F-2 e F-1 já se encontravam, respectivamente, total e parcialmente, em processo de senescência, o que determinou a redução da média. No tocante à ferrugem, Burleigh et al. (1972a) relacionam a intensidade de ferrugem da folha com o estádio de crescimento do trigo, pois eles verificaram que há o aumento da doença à medida que a cultura amadurece, como pode ser observado nas Figuras 06, 07, 09 e 10. Barcellos \& Ignaczak (1978) verificaram, em experimentos para avaliação de danos causados pela ferrugem, que o desenvolvimento da doença começa a ter significância a partir do estádio 39 (escala de Zadoks et al., 1974). As avaliações feitas em plantas marcadas, em 1994 e 1995, tiveram início após este estádio, portanto em fase que a doença exerce efeito significativo sobre a cultura. Milus (1994) também identificou o início de epidemias de ferrugem da folha a partir do estádio 39, continuando até o final da estação de cultivo. O autor indica que se 
várias avaliações de severidade fossem feitas, e se estas fossem expressas em AUDPC, seria possível a obtenção de melhores correlações entre o nível da doença e os danos por ela causados. Inclusive, Subba Rao et al. (1989b) obtiveram relação linear entre a redução da produção e a AUDPC da ferrugem da folha do trigo.

No ano de 1994, assim como em câmara de crescimento, a ferrugem apresentou, em média, maior número de lesões por área de tecido foliar do que a helmintosporiose (Figuras 06, 07 e 08), em ambos os cultivares. Porém, ao se considerar a severidade de cada uma das doenças, observa-se situação diferente. No cultivar IAC-24, em função do crescimento de suas lesões, $B$. sorokiniana apresenta maior severidade (Figura 06 - C). O cultivar BR-34 teve severidade de ferrugem maior que de helmintosporiose, devido ao alto número de pústulas de $P$. recondita por $\mathrm{cm}^{2}$ (Figura 07 - D). No ano de 1995, o cultivar IAC24 mostrou-se com manchas de helmintosporiose em maiores número e tamanho que as pústulas de ferrugem, as quais não apresentaram crescimento considerável (Figura 09). O cultivar BR-34, por sua vez, apresentou sintomas somente da ferrugem da folha, cuja severidade é função do grande número de lesões produzidas por $P$. recondita (Figura 10).

Nos experimentos realizados em condições controladas de ambiente, a ferrugem apresentou maior número de lesões, mas perdeu em severidade para a helmintosporiose, em conseqüência do crescimento de suas lesões. Em condições naturais de infecção, porém, a maior ou menor intensidade da doença, foi dependente da interação patógeno-hospedeiro, apesar dos dois cultivares de trigo utilizados serem suscetíveis a $B$. sorokiniana e a $P$. recondita. Mehta (1981b) verificou que a esporulação, o período infeccioso e a taxa de crescimento da lesão de $B$. sorokiniana apresentaram variações e foram dependentes tanto do cultivar de trigo, quanto da raça do fungo estudados. Broers (1989b) também identificou, para o patossistema $P$. recondita - trigo, interações 
cultivar-raça significativas, tanto para os dados de folha bandeira, como para a média das três folhas superiores da planta de trigo.

Independentemente do cultivar de trigo considerado, observa-se, nos dois anos agrícolas - 1994 e 1995, que a relação entre o número de lesões por $\mathrm{cm}^{2}$ e a severidade foi maior para a ferrugem da folha que para a helmintosporiose. Este fato comprova que, também em condições naturais de infecção, para promover o progresso da doença, B. sorokiniana lança mão do crescimento das suas lesões, além do aumento do número de lesões. Vitti et al. (1995), de modo semelhante ao do presente trabalho, também observaram que em condições de campo, $P$. sorghi apresenta maior número de lesões do que $E$. turcicum, mas que devido às pequenas dimensões das pústulas de ferrugem, a severidade desta doença era sempre muito baixa.

Segundo Zadoks (1971), para patógenos biotróficos causadores de lesão local, como é $P$. recondita, o sítio de infecção coincide com o tamanho da lesão. Entretanto, as lesões ocasionadas por $B$. sorokiniana, patógeno necrotrófico, possuem crescimento variável (Mehta, 1981b), o que determinaria menor número de sítios de infecção disponíveis para este patógeno, em relação à P. recondita. De acordo com Bergamin Filho \& Amorim (1996), o número de sítios sadios disponíveis num mesmo hospedeiro é maior para patógenos temperados do que para os tropicais. Estes, lançando mão do crescimento das suas lesões, tornam-se menos dependentes do clima, podendo conquistar extensas áreas do tecido foliar sem a necessidade de causar novas infecções.

Assim, verifica-se que em condições de campo, assim como ocorreu em câmaras de crescimento, o crescimento das lesões é fundamental para a conquista de tecidos do hospedeiro por B. sorokiniana, patógeno tipicamente tropical, enquanto que $P$. recondita, modelo de patógeno temperado, tem o aumento do número de lesões como base para o progresso da doença. 


\subsection{Estudos de simulação}

A Figura 11 mostra as curvas simuladas do progresso da helmintosporiose e da ferrugem da folha do trigo, com os parâmetros apresentados na Tabela 1. Observa-se o desenvolvimento mais rápido da helmintosporiose, devido ao crescimento das suas lesões. Para a ferrugem, o aparecimento de novas lesões foi responsável por $100 \%$ da severidade final da doença, enquanto que para a helmintosporiose foi a expansão de lesões que contribuiu com a maior porcentagem de doença. O aparecimento de novas lesões e o crescimento das lesões foram responsáveis, respectivamente, por 13 e $87 \%$ da quantidade de doença.

Para se avaliar quais seriam os parâmetros mais importantes para cada patossistema, foram feitas outras simulações, com variações positivas e negativas, da ordem de $20 \%$, para cada um dos parâmetros epidemiológicos do programa. As Figuras 12 e 13 trazem as curvas simuladas das doenças.

As alterações no período latente foram as que exerceram maior influência sobre a curva de progresso da helmintosporiose. Os demais parâmetros exerceram pouca ou nenhuma interferência sobre o desenvolvimento da doença (Figura 12). Quanto à ferrugem (Figura 13), a situação foi diferente. Alterações nos valores de período latente (Figura 13-A) determinaram o adiantamento ou o atraso do desenvolvimento da doença, como foi observado no caso da helmintosporiose. Caso houvesse o crescimento de lesões de $P$. recondita, este patógeno atingiria a mesma quantidade de doença que $B$. sorokiniana, com cerca de seis dias de antecedência (Figura 13-B). Mas este não é o caso, pois $P$. recondita produz lesões com crescimento insignificante (Sache \& VallavieillePope, 1993), e B. sorokiniana, possui lesões com crescimento variável (Mehta, 


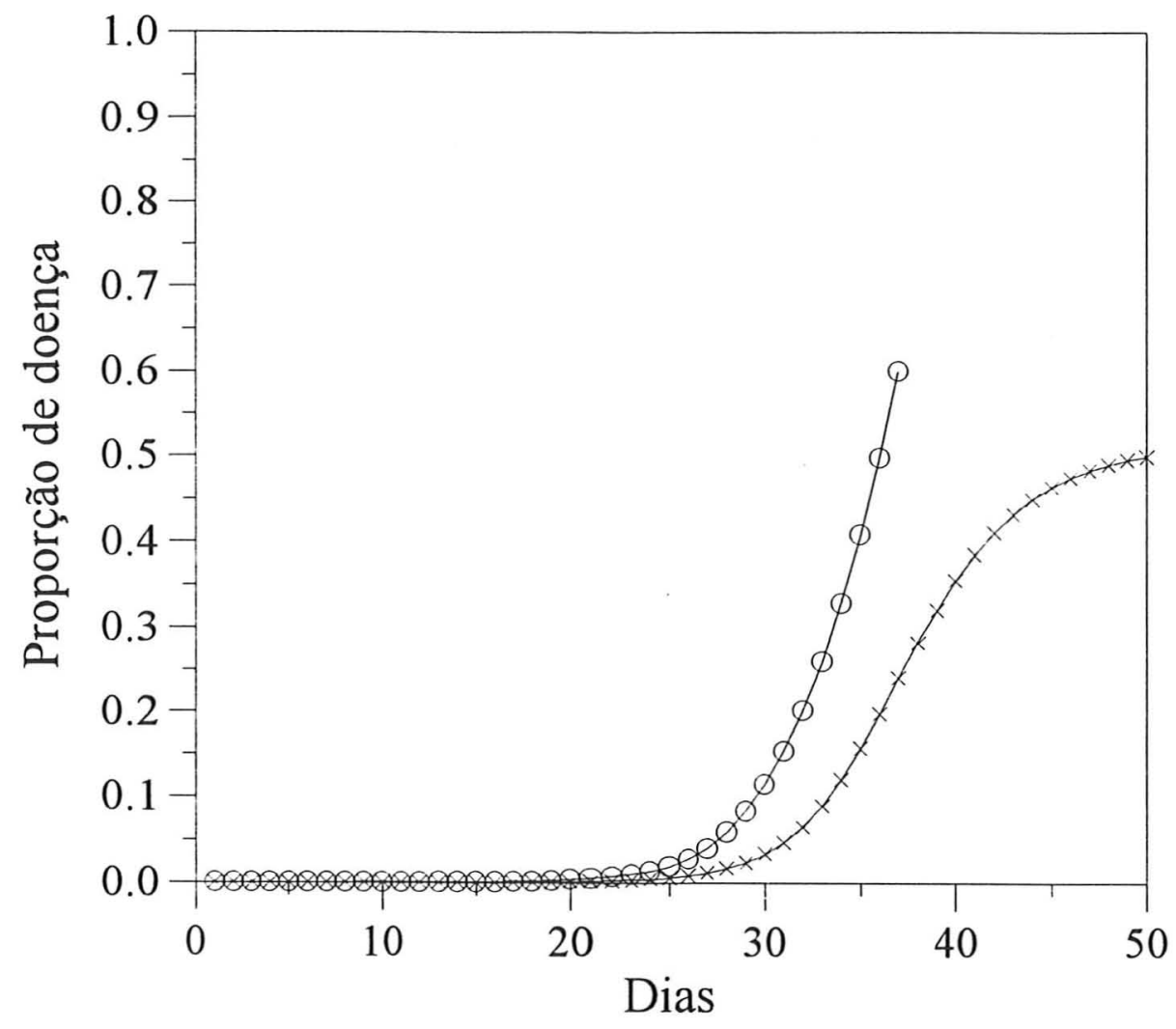

$\odot$ Helmintosporiose $\nsucc$ Ferrugem da folha

Figura 11. Simulação de curvas de progresso de epidemias de helmintosporiose, com crescimento de lesão, e de ferrugem da folha, sem crescimento de lesão.

1981b). Cada um deles caracteriza-se, então, como patógeno típico das regiões temperadas e dos trópicos, respectivamente (Bergamin Filho \& Amorim 1996).

Variações na proporção de sítios suscetíveis não alteram a curva da helmintosporiose (Figura 12-C), mas com a diminuição deste parâmetro, a ferrugem (Figura 13-C) atinge, no mesmo intervalo de tempo, quantidade de 
doença cerca de 10\% menor. Lannou et al. (1994b) analisaram, através de simulações, o efeito de misturas de plantas suscetíveis e resistentes no desenvolvimento de epidemias da ferrugem da folha $(P$. recondita $)$ e da ferrugem estriada ( $P$. striiformis) do trigo. A proporção de plantas suscetíveis não teve efeito significativo sobre a severidade da ferrugem estriada, a qual apresenta lesões de crescimento indeterminado; mas exerceu efeito significativo sobre a severidade da ferrugem da folha. Bergamin Filho \& Amorim (1996) afirmam, ainda, que o limite de exploração da "via horária de infecção" é proporcional ao número de sítios disponíveis. Uma vez que $P$. recondita baseia-se na "via horária de infecção", ou seja, no aumento do número de lesões, para o progresso da epidemia, a quantidade de sítios suscetíveis assume grande importância para este patógeno.

Diferenças pequenas foram observadas nas curvas de progresso das doenças quando foram feitas alterações na taxa básica corrigida (Figuras 12-D e 13-D). Bergamin Filho \& Amorim (1996) comentam que alterações neste parâmetro são mais importantes para os patógenos temperados, e seu efeito é antagônico ao efeito da taxa de crescimento das lesões.

Mudanças na proporção de lesões esporulantes não tiveram efeito sobre as curvas da helmintosporiose e da ferrugem (Figuras 12-E e 13-E). Segundo Zadoks (1971), a primeira pústula esporulante teria um efeito epidemiológico mais importante que centenas de pústulas que se abrem mais tarde. Para B. sorokiniana, a maior severidade é função basicamente do crescimento das lesões, sem que seja necessária a ocorrência de novas infecções. Para $P$. recondita, confirma-se a maior importância da primeira pústula que se abre sobre o desenvolvimento da epidemia, observando-se a Figura 13-A, que representa o efeito do período latente sobre o curso da epidemia. O período latente é um parâmetro de tempo diretamente relacionado com a esporulação do patógeno. 
O tamanho inicial da lesão afetou mais o desenvolvimento da ferrugem que o da helmintosporiose (Figuras 12-F e 13-F). Como a ferrugem da folha tem taxa nula de crescimento da lesão, o tamanho inicial da lesão influencia a maior ou menor severidade da doença, além de representar maior ou menor área para a produção de esporos. Já a helmintosporiose, com a característica de apresentar a expansão de lesões, o tamanho inicial destas não exerce efeito sobre o desenvolvimento da doença. De acordo com Bergamin Filho \& Amorim (1996), a severidade devida ao crescimento das lesões representa a proporção de sítios do hospedeiro ocupados unicamente pela expansão das lesões. Quanto maior o tamanho inicial da lesão, menor o número de sítios passíveis de serem ocupados pelo crescimento da lesão. 

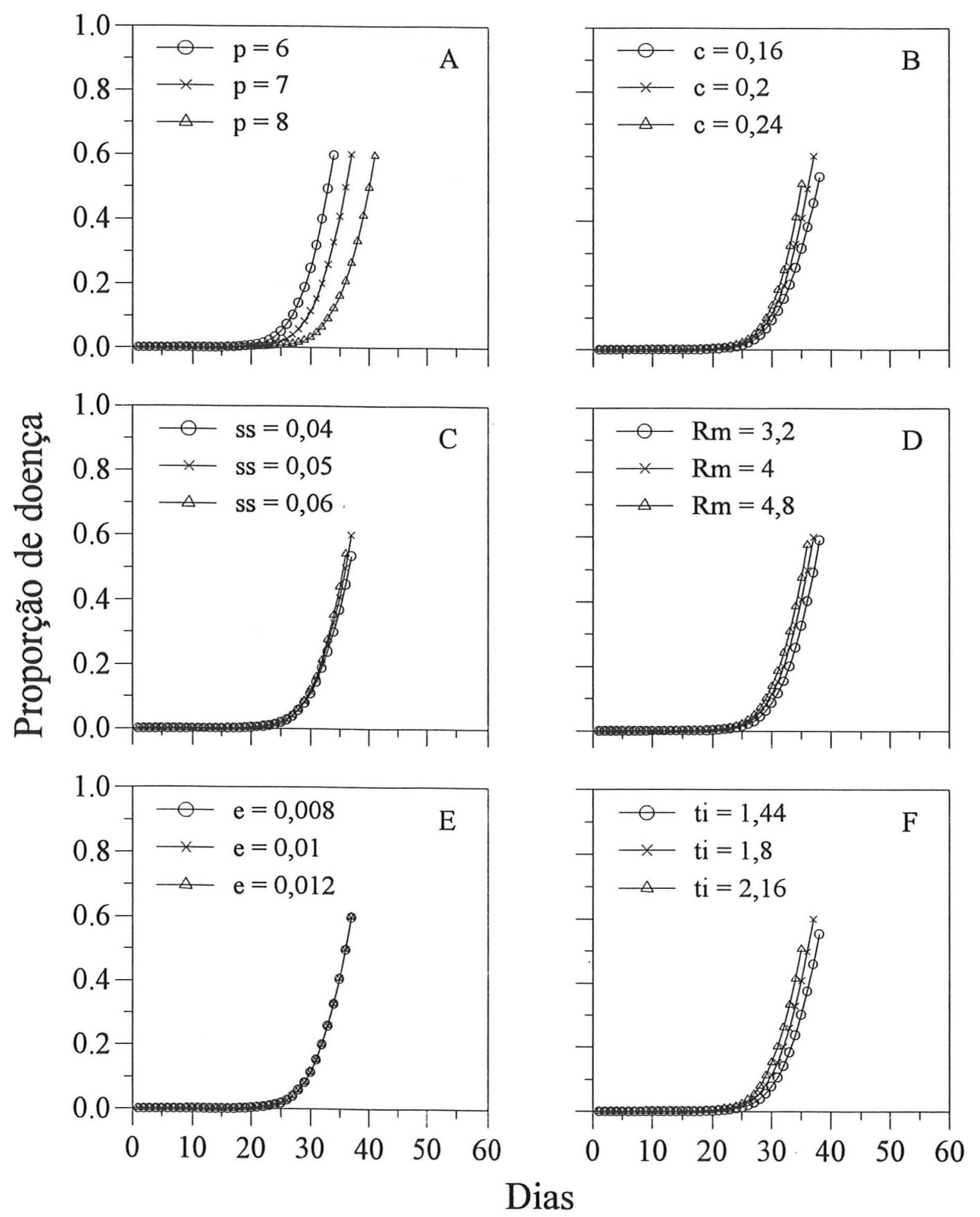

Figura 12. Curvas de progresso de epidemias de helmintosporiose do trigo, obtidas em função do efeito simulado de variações no período latente em dias (A), na taxa diária de crescimento da lesão $\mathrm{em}^{2} \mathrm{~mm}^{2}$ por dia (B), na proporção de sítios suscetíveis $(\mathrm{C})$, na máxima taxa básica de infecção em lesões por lesão por dia (D), na proporção de lesões esporulantes (E), e no tamanho inicial da lesão $\mathrm{em} \mathrm{mm}^{2}(\mathrm{~F})$. 

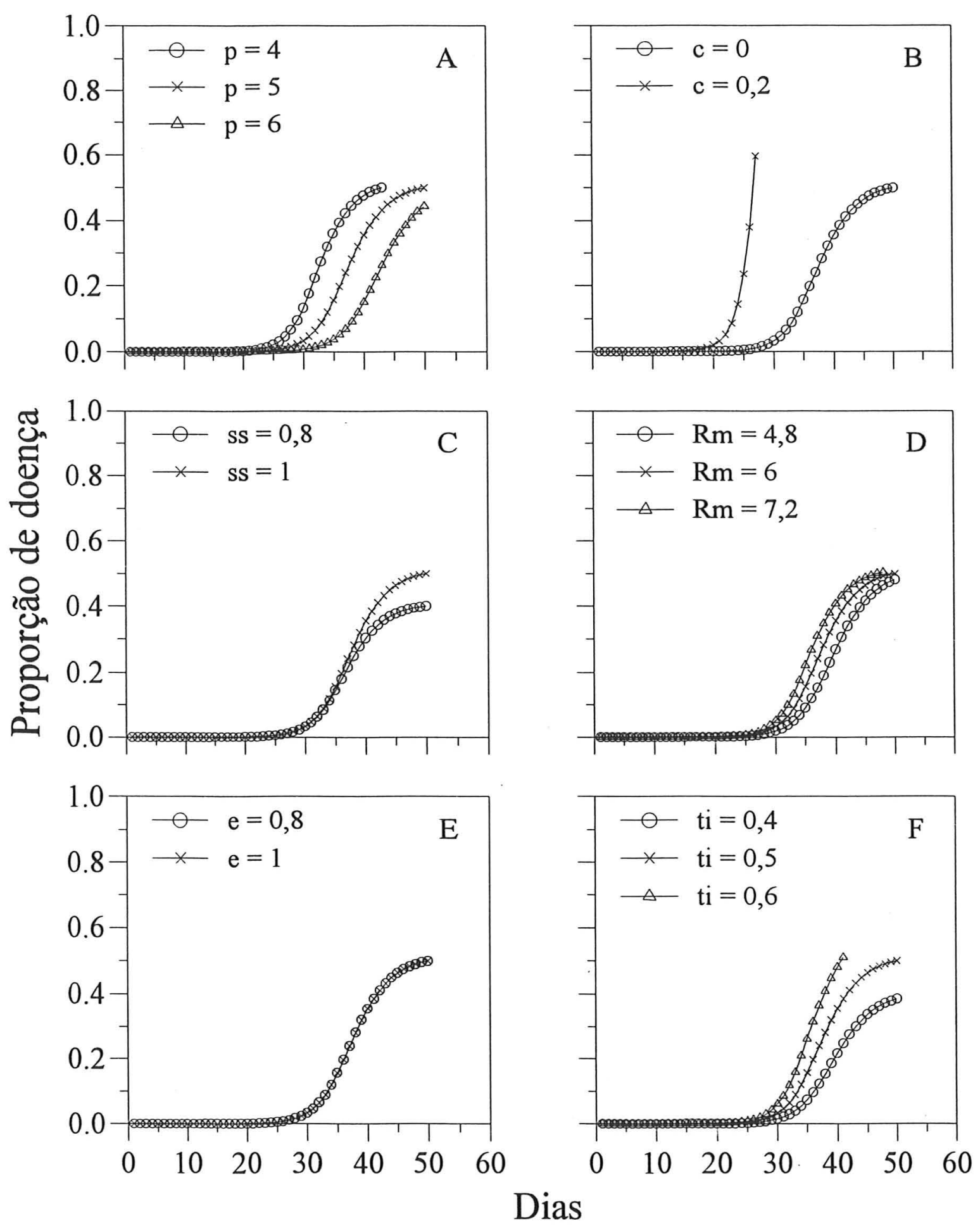

Figura 13. Curvas de progresso de epidemias de ferrugem da folha do trigo, obtidas em função do efeito simulado de variações no período latente em dias (A), na taxa diária de crescimento da lesão $\mathrm{em}^{2} \mathrm{~mm}^{2}$ por dia (B), na proporção de sítios suscetíveis $(\mathrm{C})$, na máxima taxa básica de infecção em lesões por lesão por dia (D), na proporção de lesões esporulantes (E), e no tamanho inicial da lesão $\mathrm{em} \mathrm{mm}^{2}(\mathrm{~F})$. 


\section{CONCLUSÕES}

1. Os estudos monocíclicos e policíclicos indicam que o incremento da severidade de ferrugem é principalmente função do aumento no número de pústulas nas folhas, enquanto que o de helmintosporiose é principalmente função da expansão da área de suas lesões.

2. Na faixa de temperatura analisada, a maior severidade de helmintosporiose foi obtida a $26^{\circ} \mathrm{C}$, enquanto que a de ferrugem foi obtida a $16^{\circ} \mathrm{C}$.

3. A helmintosporiose apresentou maior freqüência de infecção e menor período de incubação com o aumento da temperatura e da umidade $\left(31^{\circ} \mathrm{C}\right.$ com 24 horas de câmara úmida).

4. Simulando-se epidemias hipotéticas com e sem crescimento de lesões, é possível imitar o comportamento de patógenos tropical e temperado, respectivamente.

5. A ferrugem, causada por $P$. recondita, estaria mais adaptada às condições de clima de regiões temperadas, onde predominam, durante a estação de cultivo, temperaturas amenas e abundância de orvalho. B. sorokiniana, agente causal da helmintosporiose, apresentaria uma maior vulnerabilidade às baixas temperaturas e maior adaptabilidade a condições de estresse hídrico. 


\section{REFERÊNCIAS BIBLIOGRÁFICAS}

AUST, H.J.; BASHI, E.; ROTEM, J. Flexibility of plant pathogens in exploiting ecological and biotic conditions in the development of epidemics. In: INTERNATIONAL CONGRESS OF PLANT PATHOLOGY, 3., Munich, 1978. Comparative epidemiology: a tool for better disease management; proceedings. Wageningen: Centre for Agricultural Publishing and Documentation, 1980. p. 46-56.

BARCELLOS, A.L.; IGNACZAK, J.C. Efeito da ferrugem da folha em diferentes estádios de desenvolvimento do trigo. In: REUNIÃO ANUAL CONJUNTA DE PESQUISA DE TRIGO, 10., Porto Alegre, 1978. Solos e técnicas culturais, economia e sanidade. Passo Fundo: EMBRAPA, 1978. p. 212-19.

BARROS, B.C. Trigo-Brasil: o papel das doenças na baixa produtividade. Correio Agrícola, n.2, p. 703-10, 1985.

BASHI, E.; ROTEM, J. Adaptation of four pathogens to semi-arid habitats as conditioned by penetration rate and germinating spore survival. Phytopathology, v.64, n.7, p. 1035-9, 1974.

BERGAMIN FILHO, A. Structure, behavior and management of tropical foliar plant pathosystems. In: INTERNATIONAL WORKSHOP ON PLANT 
DISEASE EPIDEMIOLOGY, 6., Giessen, 1990. Summary. Giessen: 1990. $1 \mathrm{v}$.

BERGAMIN FILHO, A.; AMORIM, L., ed. Doenças de plantas tropicais: epidemiologia e controle econômico. São Paulo: Agronômica Ceres, 1996. 289 p.

BERGAMIN FILHO, A.; FEGIES, N.C.; MENDES, B.M.J. Different patterns of spore production during the infectious period: a simulation study. In: INTERNATIONAL WORKSHOP ON EPIDEMIOLOGY OF PLANT DISEASES, 5., Jerusalem, 1986. Summaries of contributions. Jerusalem: 1986. 1v.

BERGER, R.D. Helminthosporium turcicum lesion numbers related to numbers of trapped spores and fungicide sprays. Phytopathology, v.63, n.7, p. 930-3, 1973.

BERGER, R.D. Application of epidemiological principles to achieve plant disease control. Annual Review of Phytopathology, v.15, p. 165-83, 1977.

BERGER, R.D.; BARTZ, J.A. Analysis of monocyclic pathosystems with Erwinia-Lycopersicon as the model. Phytopathology, v.72, n.4, p. 365-9, 1982.

BERGER, R.D.; BERGAMIN FILHO, A. A model for the expansion of cohorts of lesions on cohorts of leaves. In: ANNUAL MEETING OF THE AMERICAN PHYTOPATHOLOGICAL SOCIETY AND THE CANADIAN PHYTOPATHOLOGICAL SOCIETY, Grand Rapids, 1990. Abstracts of presentations. Phytopathology, v.80, n.10, p. 996, 1990. 
BERGER, R.D.; JONES, J.W. A general model for disease progress with functions for variable latency and lesion expansion on growing host plants. Phytopathology, v.75, n.7, p. 792-7, 1985.

BIGGS, A.R.; NORTHOVER, J. Influence of temperature and wetness duration on infection of peach and sweet cherry fruits by Monilinia fructicola. Phytopathology, v.78, n.10, p. 1352-6, 1988.

BROERS, L.H.M. Influence of development stage and host genotype on three components of partial resistance to leaf rust in spring wheat. Euphytica, v.44, n.3, p. 187-95, 1989a.

BROERS, L.H.M. Race-specific aspects of partial resistance in wheat to wheat leaf rust, Puccinia recondita f. sp. tritici. Euphytica, v.44, n.3, p. 273-82, $1989 b$.

BROERS, L.H.M.; WALLENBURG, S.C. Influence of post-infection temperature on three components of partial resistance in wheat to wheat leaf rust. Euphytica, v.44, n.3, p. 215-24, 1989.

BROWDER, L.E. Parasite : host : environment specificity in the cereal rusts. Annual Review of Phytopathology, v.23, p. 201-22, 1985.

BROWNING, J.A.; FREY, K.J. Multiline cultivars as a means of disease control. Annual Review of Phytopathology, v.7, p. 355-82, 1969.

BUDDENHAGEN, I.W. Breeding strategies for stress and disease resistance in developing countries. Annual Review of Phytopathology, v.21, p. 385-409, 1983. 
BURLEIGH, J.R.; EVERSMEYER, M.G.; ROELFS, A.P. Development of linear equations for predicting wheat leaf rust. Phytopathology, v.62, n.9, p. 94753, 1972a.

BURLEIGH, J.R.; ROELFS, A.P.; EVERSMEYER, M.G. Estimating damage to wheat caused by Puccinia recondita tritici. Phytopathology, v.62, n.9, p. 944-6, 1972b.

BUTLER, D.R.; JADHAV, D.R. Requirements of leaf wetness and temperature for infection of groundnut by rust. Plant Pathology, v.40, n.3, p. 395-400, 1991.

CALPOUZOS, L. Some contributions from the tropics to plant disease control methods. Phytopathology, v.52, n.9, p. 942-5, 1962.

CAMPBELL, C.L.; MADDEN, L.V. Introduction to plant disease epidemiology. New York: John Wiley, 1990. 532p.

CARDOSO, E.J.B.N.; KIMATI, H. Doenças do trigo - Triticum spp. In: GALLI, F., coord. Manual de fitopatologia. 2.ed. São Paulo: Agronômica Ceres, 1980. v.2: Doenças das plantas cultivadas. cap. 36, p. 553-73.

CARISSE, O.; KUSHALAPPA, A.C.; CLOUTIER, D.C. Influence of temperature, leaf wetness, and high relative humidity duration on sporulation of Cercospora carotae on carrot leaves. Phytopathology, v.83, n.3, p. 33843, 1993.

CASTOR, L.L.; AYERS, J.E.; NELSON, R.R. Controlled-environment studies of the epidemiology of yellow leaf blight of corn. Phytopathology, v.67, n.1, p. 85-90, 1977. 
CASTRO, H.A. de.; BERGAMIN FILHO, A.; KRÜGNER, T.L. Padrão de produção de uredosporos em mudas de Eucaliptus spp inoculadas artificialmente com Puccinia psidii. Summa Phytopathologica, v.10, n.1/2, p. $155-70,1984$.

CHINN, S.H.F. Influence of fungicide sprays on sporulation of Cochliobolus sativus on Cypress wheat and on conidial populations in soil. Phytopathology, v.67, n.1, p. 133-8, 1977.

CLARK, R.V.; DICKSON, J.G. The influence of temperature on disease development in barley infected by Helminthosporium sativum. Phytopathology, v.48, n.6, p. 305-10, 1958.

COHEN, Y.; ROTEM, J. The relationship of sporulation to photosynthesis in some obligatory and facultative parasites. Phytopathology, v.60, n.11, p. 1600-4, 1970.

COLHOUN, J. Effects of environmental factors on plant disease. Annual Review of Phytopathology, v.11, p. 343-64, 1973.

COUTURE, L.; SUTTON, J.C. Relation of weather variables and host factors to incidence of airborne spores of Bipolaris sorokiniana. Canadian Journal of Botany, v.56, n.17, p. 2162-70, 1978.

DENISSEN, C.J.M. Influence of race and post infection temperature on two components of partial resistance to wheat leaf rust in seedlings of wheat. Euphytica, v.58, n.1, p. 13-20, 1991.

DENISSEN, C.J.M. Components of adult plant resistance to leaf rust in wheat. Euphytica, v.70, n.1/2, p. 131-40, 1993. 
DUCZEK, L.J. Sporulation of Cochliobolus sativus on crown and underground parts of spring cereals in relation to weather and host species, cultivar, and phenology. Canadian Journal of Plant Pathology, v.12, n.3, p. 273-8, 1990.

DUCZEK, L.J. Constitutive dormancy in conidia of Bipolaris sorokiniana. Canadian Journal of Plant Pathology, v.16, n.4, p. 347-9, 1994.

DUCZEK, L.J.; WILDERMUTH, G.B. Effect of temperature, freezing period, and drying on the sporulation of Cochliobolus sativus on mature stem bases of wheat. Canadian Journal of Plant Pathology, v.14, n.2, p. 130-6, 1992.

EMGE, R.G.; KINGSOLVER, C.H.; JOHNSON, D.R. Growth of the sporulating zone of Puccinia striiformis and its relationship to stripe rust epiphytology. Phytopathology, v.65, n.6, p. 679-81, 1975.

EVERSMEYER, M.G.; BURLEIGH, J.R. A method of predicting epidemic development of wheat leaf rust. Phytopathology, v.60, n.5, p. 805-11, 1970.

EVERSMEYER, M.G.; KRAMER, C.L. Local dispersal of inoculum from a wheat plot. In: INTERNATIONAL WORKSHOP ON PLANT DISEASE EPIDEMIOLOGY, 6., Giessen, 1990. Summary. Giessen: 1990a. 1v.

EVERSMEYER, M.G.; KRAMER, C.L. Models for forecasting multiple disease losses in Kansas wheat production. In: INTERNATIONAL WORKSHOP ON PLANT DISEASE EPIDEMIOLOGY, 6., Giessen, 1990. Summary. Giessen: 1990b. 1v.

EVERSMEYER, M.G.; KRAMER, C.L. Survival of Puccinia recondita and P. graminis urediniospores in the atmosphere. In: INTERNATIONAL 
WORKSHOP ON PLANT DISEASE EPIDEMIOLOGY, 6., Giessen, 1990. Summary. Giessen: 1990c. 1v.

EVERSMEYER, M.G.; KRAMER, C.L. Survival of Puccinia recondita and P. graminis urediniospores as affected by exposure to weather conditions at one meter. Phytopathology, v.84, n.4, p. 332-5, 1994.

EVERSMEYER, M.G.; KRAMER, C.L.; BROWDER, L.E. Effect of temperature and host : parasite combination on the latent period of Puccinia recondita in seedling wheat plants. Phytopathology, v.70, n.10, p. 938-41, 1980.

EVERSMEYER, M.G.; KRAMER, C.L.; BROWDER, L.E. Presence, viability, and movement of Puccinia recondita and P. graminis inoculum in the Great Plains. Plant Disease, v.68, n.5, p. 392-5, 1984.

EVERSMEYER, M.G.; KRAMER, C.L.; BROWDER, L.E. Winter and early spring survival of Puccinia recondita on Kansas wheat during 1980-1986. Plant Disease, v.72, n.12, p. 1074-6, 1988.

EYAL, Z.; PETERSON, J.L. Uredospore production of five races of Puccinia recondita Rob. ex. Desm. as affected by light and temperature. Canadian Journal of Botany, v.45, n.4, p. 537-9, 1967.

EZZAHIRI, B.; DIOURI, S. Pathogenicity of Puccinia recondita f. sp. tritici in Morocco during 1985, 1988, 1990, and 1992. Plant Disease, v.78, n.4, p. 407-10, 1994.

FEGIES, N.C. Desenvolvimento de modelo para simulação da progressão de doenças de plantas. Piracicaba, 1985. 102p. Dissertação (Mestrado) - 
Escola Superior de Agricultura "Luiz de Queiroz", Universidade de São Paulo.

FERNANDES, J.M.C.; HENDRIX, J.W. Leaf wetness and temperature effects on the hyphal growth and symptoms development on wheat leaves infected by Septoria nodorum blotch. Fitopatologia Brasileira, v.11, n.2, p. 835-45, 1986.

FETCH Jr., T.G.; STEFFENSON, B.J. Identification of Cochliobolus sativus isolates expressing differential virulence on two-row barley genotypes from North Dakota. Canadian Journal of Plant Pathology, v.16, n.3, p. 202-6, 1994.

GALLAGHER, J.N.; BISCOE, P.V.; SCOTT, R.K. Barley and its environment. VI. Growth and development in relation to yield. The Journal of Applied Ecology, v.13, n.2, p. 563-83, 1976.

GIVAN, C.V.; BROMFIELD, K.R. Light inhibition of uredospore germination in Puccinia graminis var. tritici. Phytopathology, v.54, n.4, p. 382-4, 1964a.

GIVAN, C.V.; BROMFIELD, K.R. Light inhibition of uredospore germination in Puccinia recondita. Phytopathology, v.54, n.1, p. 116-7, 1964 b.

GOULART, A.C.P.; PAIVA, F. de A. Controle das ferrugens do trigo com fungicidas triazóis em dose normal e em metade da dose isolados ou em mistura ao mancozebe. Fitopatologia Brasileira, v.17, n.1, p. 80-3, 1992.

GRANT, T.J. The role of plant pathology in tropical plantation agriculture. Phytopathology, v.52, n.9, p. 930-6, 1962. 
HABTU, A.; ZADOKS, J.C. Components of partial resistance in phaseolus beans against an Ethiopian isolate of bean rust. Euphytica, v.83, n.2, p. 95-102, 1995.

HAU, B.; KRANZ, J. Mathematics and statistics for analysis in epidemiology. In: KRANZ, J., ed. Epidemics of plant diseases: mathematical analysis and modeling. 2.ed. Berlin: Springer-Verlag, 1990. cap. 2, p. 12-52.

HAU, B.; AMORIM, L.; BERGAMIN FILHO, A. Mathematical functions to describe disease progress curves of double sigmoid pattern. Phytopathology, v.83, n.9, p. 928-32, 1993.

HEADRICK, J.M.; PATAKY, J.K. Expression of partial resistance to common rust in sweet corn hybrids at various host growth stages. Phytopathology, v.77, n.3, p. 454-8, 1987.

HEAGLE, A.S.; MOORE, M.B. Some effects of moderate adult resistance to crown rust on oats. Phytopathology, v.60, n.3, p. 461-6, 1970.

HOSFORD Jr., R.M.; LAREZ, C.R.; HAMMOND, J.J. Interaction of wet period and temperature on Pyrenophora tritici-repentis infection and development in wheats of differing resistance. Phytopathology, v.77, n.7, p. 1021-7, 1987.

HWANG, L. The effect of light and temperature on the viability of urediospores of certain cereal rusts. Phytopathology, v.32, n.8, p. 699-711, 1942.

IMHOFF, M.W.; LEONARD, K.J.; MAIN, C.E. Analysis of disease progress curves, gradients, and incidence-severity relationships for field and phytotron bean rust epidemics. Phytopathology, v.72, n.1, p. 72-80, 1982a. 
IMHOFF, M.W.; LEONARD, K.J.; MAIN, C.E. Patterns of bean rust lesion size increase and spore production. Phytopathology, v.72, n.4, p. 441-6, 1982b.

JACOME, L.H.; SCHUH, W. Effects of leaf wetness duration and temperature on development of Black Sigatoka disease on banana infected by Mycosphaerella fijiensis var. difformis. Phytopathology, v.82, n.5, p. 51520, 1992.

JAMES, W.C.; SHIH, C.S. Relationship between incidence and severity of powdery mildew and leaf rust on winter wheat. Phytopathology, v.63, n.1, p. 183-7, 1973.

JANZEN, D.H. Tropical agroecosystems. Science, v.182, n.4118, p. 1212-9, 1973.

JOHNSON, R.; TAYLOR, A.J. Spore yield of pathogens in investigations of the race-specificity of host resistance. Annual Review of Phytopathology, v.14, p. 97-119, 1976.

KAUL, K.; SHANER, G. Effect of temperature on adult-plant resistance to leaf rust in wheat. Phytopathology, v.79, n.4, p. 391-4, 1989.

KOLMER, J.A. Physiologic specialization of Puccinia recondita f. sp. tritici in Canada in 1989. Canadian Journal of Plant Pathology, v.12, n.1, p. 428$30,1990$.

KOLMER, J.A. Diversity of virulence phenotypes and effect of host sampling between and within populations of Puccinia recondita f. sp. tritici in Canada. Plant Disease, v.76, n.6, p. 618-21, 1992. 
KRANZ, J. Comparison of epidemics. Annual Review of Phytopathology, v.12, p. 355-74, 1974.

KRANZ, J. Comparative anatomy of epidemics. In: HORSFALL, J.G.; COWLING, E.B., ed. Plant disease: an advanced treatise. New York: Academic Press, 1978. v.2: How disease develops in populations. cap. 3, p. $33-62$.

KRANZ, J. Comparative epidemiology: an evaluation of scope, concepts and methods. In: INTERNATIONAL CONGRESS OF PLANT PATHOLOGY, 3., Munich, 1978. Comparative epidemiology: a tool for better disease management, proceedings. Wageningen: Centre for Agricultural Publishing and Documentation, 1980. p. 18-28.

KRANZ, J. The methodology of comparative epidemiology. In: KRANZ, J.; ROTEM, J., ed. Experimental techniques in plant disease epidemiology. Berlin: Springer-Verlag, 1988. cap. 20, p. 279-89.

KUHN, R.C.; OHM, H.W.; SHANER, G.E. Slow leaf-rusting resistance in wheat against twenty-two isolates of Puccinia recondita. Phytopathology, v.68, n.4, p. 651-6, 1978.

LANNOU, C.; VALLAVIEILLE-POPE, C. de.; GOYEAU, H. Host mixture efficacy in disease control: effects of lesion growth analyzed through computer-simulated epidemics. Plant Pathology, v.43, n.4, p. 651-62, 1994a.

LANNOU, C.; VALLAVIEILLE-POPE, C. de.; BIASS, C.; GOYEAU, H. The efficacy of mixtures of susceptible and resistant hosts to two wheat rusts of 
different lesion size: controlled condition experiments and computerized simulations. Journal of Phytopathology, v.140, n.3, p. 227-37, 1994 b.

LARGE, E.C. Growth stages in cereals, illustration of the Feekes scale. Plant Pathology, v.3, p. 128-9, 1954.

LEDINGHAM, R.J. Survival of Cochliobolus sativus conidia in pure culture and in natural soil at different relative humidities. Canadian Journal of Botany, v.48, n.10, p. 1893-6, 1970.

LEONARD, K.J. Factors affecting rates of stem rust increase in mixed plantings of susceptible and resistant oat varieties. Phytopathology, v.59, n.12, p.1845-50, 1969.

LONG, D.L.; KOLMER, J.A. A North American system of nomenclature for Puccinia recondita f. sp. tritici. Phytopathology, v.79, n.5, p. 525-9, 1989.

LUKE, H.H.; BERGER, R.D. Slow rusting in oats compared with the logistic and Gompertz models. Phytopathology, v.72, n.4, p. 400-2, 1982.

LUTHRA, J.K.; RAO, M.V. Multiline cultivars - how their resistance influence rust diseases in wheat. Euphytica, v.28, n.1, p. 137-44, 1979.

LUZ, W.C. da. Influência do período de umidificação pós-inoculação na reação de cultivares de trigo à mancha foliar (Cochliobolus sativus). Fitopatologia Brasileira, v.7, n.1, p. 111-5, 1982.

LUZ, W.C. da. Yield losses caused by fungal foliar wheat pathogens in Brazil. Phytopathology, v.74, n.12, p. 1403-7, 1984. 
LUZ, W.C. da.; BERGSTROM, G.C. Temperature-sensitive development of spot blotch in spring wheat cultivars differing in resistance. Fitopatologia Brasileira, v.11, n.1, p. 197-204, 1986.

MEHTA, Y.R. Doenças do trigo e seu controle. São Paulo: Agronômica Ceres, 1978. 190p.

MEHTA, Y.R. Identification of races of Helminthosporium sativum of wheat in Brazil. Pesquisa Agropecuária Brasileira, v.16, n.3, p. 331-6, 1981 .

MEHTA, Y.R. Produção de conídios, período de esporulação e extensão da lesão por Helminthosporium sativum nas folhas-bandeira de trigo. Pesquisa Agropecuária Brasileira, v.16, n. 1, p. 77-99, 1981 b.

MEHTA, Y.R. Manejo integrado de enfermedades del trigo. Santa Cruz de la Sierra: Imprenta Landivar S.R.L., 1993. 314p.

MEHTA, Y.R.; IGARASHI, S. Partial resistance in wheat against Puccinia recondita, a new view on its detection and measuring. Summa Phytopathologica, v.5, n.1/2, p. 90-100, 1979.

MEHTA, Y.R.; ZADOKS, J.C. Uredospore production and sporulation period of Puccinia recondita f. sp. triticina on primary leaves of wheat. Netherlands Journal of Plant Pathology, v.76, p. 267-76, 1970.

MEHTA, Y.R.; NAZARENO, N.R.X.; IGARASHI, S. Avaliação de perdas causadas pelas doenças do trigo. Summa Phytopathologica, v.5, n.3/4, p. 113-7, 1979. 
MEHTA, Y.R.; RIEDE, C.R.; CAMPOS, L.A.C.; KOHLI, M.M. Integrated management of major wheat diseases in Brazil: an example for the Southern Cone region of Latin America. Crop Protection, v.11, n.6, p. 517-24, 1992.

MENDES, B.M.J.; BERGAMIN FILHO, A. Influência da idade da folha na quantificação dos parâmetros monocíclicos da ferrugem do feijoeiro (Uromyces phaseoli var. typica). Fitopatologia Brasileira, v.14, n.1, p. 26-8, 1989.

MENDES, B.M.J.; BERGAMIN FILHO, A. Período infeccioso e esporulação de Uromyces phaseoli var. typica. Fitopatologia Brasileira, v.15, n.1, p. 54-7, 1990.

MILUS, E.A. Effects of leaf rust and Septoria leaf blotch on yield and test weight of wheat in Arkansas. Plant Disease, v.78, n.1, p. 55-9, 1994.

MORENO, R.A. Plant pathology in the small farm context. Annual Review of Phytopathology, v.23, p. 491-512, 1985.

MORTON, D.J. Influence of temperature, humidity, and inoculum concentration on development of Helminthosporium sativum and Septoria passerinii in excised barley leaves. Phytopathology, v.52, n.7, p. 704-8, 1962.

NUTTER Jr., F.W.; PEDERSON, V.D.; FOSTER, A.E. Effect of inoculations with Cochliobolus sativus at specific growth stages on grain yield and quality of malting barley. Crop Science, v.25, n.6, p. 933-8, 1985.

OHM, H.W.; SHANER, G.E. Three components of slow leaf-rusting at different growth stages in wheat. Phytopathology, v.66, n.11, p. 1356-60, 1976. 
PADDOCK, W.C. Phytopathology in a hungry world. Annual Review of Phytopathology, v.5, p. 375-90, 1967.

PARLEVLIET, J.E. Partial resistance of barley to leaf rust Puccinia hordei. I. Effect of cultivar and development stage on latent period. Euphytica, v.24, n.1, p. 21-7, 1975.

PARLEVLIET, J.E. Components of resistance that reduce the rate of epidemic development. Annual Review of Phytopathology, v.17, p. 203-22, 1979.

PARLEVLIET, J.E. Pleiotropic association of infection frequency and latent period of two barley cultivars partially resistant to barley leaf rust. Euphytica, v.35, n.1, p. 267-72, 1986.

PARLEVLIET, J.E.; VAN OMMEREN, A. Partial resistance of barley to leaf rust, Puccinia hordei. II. Relationship between field trials, micro plot tests and latent period. Euphytica, v.24, n.2, p. 293-303, 1975.

PICININI, E.C.; PRESTES, A.M. Trigo: fungos, prejuízo certo na lavoura. A Granja, n.450, p. 54-6, 1985.

POLITOWSKI, K.; BROWNING, J.A. Effect of temperature, light, and dew duration on relative numbers of infection structrures of Puccinia coronata avenae. Phytopathology, v.65, n. 12, p. 1400-4, 1975.

PUTTER, C.A.J. The management of epidemic levels of endemic diseases under tropical subsistence farming conditions. In: INTERNATIONAL CONGRESS OF PLANT PATHOLOGY, 3., Munich, 1978. Comparative epidemiology: a tool for better disease management; proceedings. Wageningen: Centre for Agricultural Publishing and Documentation, 1980. p. 93-103. 
REIS, E.M. Doenças do trigo. I. Podridão comum de raízes - Helmintosporiose. São Paulo: Companhia Nacional de Defensivos Agrícolas, 1988. 20p.

REIS, E.M.; AMBROSI, I. Efeito de rotação de culturas de inverno na densidade de inóculo de Helminthosporium sativum no solo, nas podridões radiculares e no rendimento do trigo. Fitopatologia Brasileira, v.12, n.4, p. 365-8, 1987.

REIS, E.M.; SANTOS, H.P. The increased sporulation of Cochliobolus sativus on above-ground tissues of small grains and its relationship to the origin of inoculum in the soil. Fitopatologia Brasileira, v.12, n.3, p. 206-8, 1987.

REIS, E.M.; WÜNSCHE, W.A. Sporulation of Cochliobolus sativus on residues of winter crops and its relationship to the increase of inoculum density in soil. Plant Disease, v.68, n.5, p. 411-2, 1984.

REIS, E.M.; MOREIRA, J.C.S.; PRESTES, A.M. Multiplicação de Septoria nodorum, S. tritici e Helminthosporium sativum em folhas senescentes de dez cultivares de trigo em três épocas de semeadura, sob condições naturais, em 1984. Fitopatologia Brasileira, v.12, n.3, p. 198-202, 1987.

ROTEM, J. Techniques of controlled-condition experiments. In: KRANZ, J.; ROTEM, J., ed. Experimental techniques in plant disease epidemiology. Berlin: Springer-Verlag, 1988. cap. 2, p. 19-31.

ROTEM, J.; PALTI, J. Epidemiological factors as related to plant disease control by cultural practices. In: INTERNATIONAL CONGRESS OF PLANT PATHOLOGY, 3., Munich, 1978. Comparative epidemiology: a tool for better disease management; proceedings. Wageningen: Centre for Agricultural Publishing and Documentation, 1980. p. 104-16. 
SACHE, I.; VALLAVIEILLE-POPE, C. de. Comparison of the wheat brown and yellow rusts for monocyclic sporulation and infection processes, and their polycyclic consequences. Journal of Phytopathology, v.138, n.1, p. 55-65, 1993.

SENTELHAS, P.C. Ocorrência de helmintosporiose (Helminthosporium sativum) e de oídio (Erysiphe graminis) na cultura do trigo (Triticum aestivum, L.) sob diferentes condições microclimáticas. Piracicaba, 1992. 103p. Dissertação (Mestrado) - Escola Superior de Agricultura "Luiz de Queiroz", Universidade de São Paulo.

SENTELHAS, P.C.; PEDRO Jr., M.J.; FELÍCIO, J.C.; IGUE, T. Estimativa agrometeorológica da ocorrência de helmintosporiose e oídio em trigo. Summa Phytopathologica, v.19, n.3,4, p. 180-3, 1993.

SEQUEIRA, L. Special contributions from the tropics to phytopathological mycology. Phytopathology, v.52, n.9, p. 936-42, 1962.

SHANER, G. Reduced infectability and inoculum production as factors of slow mildewing in Knox wheat. Phytopathology, v.63, n.10, p. 1307-11, 1973.

SHANER, G. Effect of environment on fungal leaf blights of small grains. Annual Review of Phytopathology, v. 19, p. 273-96, 1981.

SHANER, G.; BUECHLEY, G. Epidemiology of leaf blotch of soft red winter wheat caused by Septoria tritici and Stagonospora nodorum. Plant Disease, v.79, n.9, p. 928-38, 1995.

SHANER, G.; HESS, F.D. Equations for integrating components of slow leafrusting resistance in wheat. Phytopathology, v.68, n.10, p. 1464-9, 1978. 
SHOEMAKER, R.A. Biology, cytology, and taxonomy of Cochliobolus sativus. Canadian Journal of Botany, v.33, n.6, p. 562-76, 1955.

STATLER, G.D.; CHRISTIANSON, T. Temperature studies with wheat leaf rust. Canadian Journal of Plant Pathology, v.15, n.2, p. 97-101, 1993.

SUBBA RAO, K.V.; SNOW, J.P.; BERGGREN, G.T. Detection, viability, and possible sources of urediniospores of Puccinia recondita $\mathrm{f}$. sp. tritici in Louisiana. Plant Disease, v.73, n.5, p. 437-42, 1989a.

SUBBA RAO, K.V.; SNOW, J.P.; BERGGREN, G.T. Effect of growth stage and initial inoculum level on leaf rust development and yield loss caused by Puccinia recondita f. sp. tritici. Journal of Phytopathology, v.127, n.3, p. 200-10, 1989 b.

TENG, P.S. Estimating and interpreting disease intensity and loss in commercial fields. Phytopathology, v.73, n.11, p. 1587-90, 1983.

TENG, P.S. A comparison of simulation approaches to epidemic modeling. Annual Review of Phytopathology, v.23, p. 351-79, 1985.

THORNE, G.N. Distribution between parts of the main shoot and the tillers of photosynthate produced before and after anthesis in the top three leaves of main shoots of Hobbit and Maris Huntsman winter wheat. Annals of Applied Biology, v.101, n.3, p. 553-9, 1982.

TOMERLIN, J.R.; EVERSMEYER, M.G.; KRAMER, C.L.; BROWDER, L.E. Temperature and host effects on latent and infectious periods and on urediniospore production of Puccinia recondita f. sp. tritici. Phytopathology, v.73, n.3, p. 414-9, 1983. 
TORRES, G.A.M.; AMORIM, L.; BERGAMIN FILHO, A. Influência da temperatura e da umidade na quantificação de parâmetros monocíclicos da ferrugem da folha do trigo. In: CONGRESSO BRASILEIRO DE FITOPATOLOGIA, 28., Ilhéus, 1995. Resumos. Fitopatologia Brasileira, v.20, p. 305, 1995.

TOTTMAN, D.R.; MAKEPEACE, R.J. An explanation of the decimal code for the growth stages of cereals, with illustrations. Annals of Applied Biology, v.93, n.2, p. 221-34, 1979.

VALLAVIEILLE-POPE, C. de.; HUBER, L.; LECONTE, M.; GOYEAU, H. Comparative effects of temperature and interrupted wet periods on germination, penetration, and infection of Puccinia recondita $\mathrm{f}$. sp. tritici and P. striiformis on wheat seedlings. Phytopathology, v.85, n.4, p. 409-15, 1995.

VANDERPLANK, J.E. Plant diseases: epidemics and control. New York: Academic Press, 1963. 344p.

VECHIATO, M.H.; LASCA, C.C.; VALARINI, P.J. Sobrevivência do fungo Helminthosporium sativum em sementes de trigo (Triticum aestivum) armazenadas. Fitopatologia Brasileira, v.12, n.3, p. 226-31, 1987.

VILLAREAL, R.L.; MUJEEB-KAZI, A.; GILCHRIST, L.I.; DEL TORO, E. Yield loss to spot blotch in spring bread wheat in warm nontraditional wheat production areas. Plant Disease, v.79, n.9, p. 893-7, 1995.

VITTI, A.J. Epidemiologia comparativa entre a ferrugem comum (Puccinia sorghi SCHWEINITZ) e a helmintosporiose (Exserohilum turcicum (PASSERINI) LEONARD \& SUGGS) do milho (Zea mays L.). Piracicaba, 
1993. 102p. Dissertação (Mestrado) - Escola Superior de Agricultura "Luiz de Queiroz", Universidade de São Paulo.

VITTI, A.J.; BERGAMIN FILHO, A.; AMORIM, L.; FEGIES, N. de C. Epidemiologia comparativa entre a ferrugem comum e a helmintosporiose do milho. II. Desenvolvimento de epidemias sob condições naturais de infecção. Summa Phytopathologica, v.21, n.2, p.131-3, 1995.

WALLER, J.M. The influence of climate on the incidence and severity of some diseases of tropical crops. Review of Plant Pathology, v.55, n.3, p. 185-94, 1976.

WELLMAN, F.L. A few introductory features of tropical plant pathology. Phytopathology, v.52, n.9, p. 928-30, 1962.

WELTY, R.E.; BARKER, R.E. Evaluation of resistance to stem rust in perennial ryegrass grown in controlled and field conditions. Plant Disease, v.76, n.6, p. 637-41, 1992.

WIESE, M.V. Compendium of wheat diseases. 2.ed. St. Paul: APS, 1987. $112 p$.

WIESE, M.V.; RAVENSCROFT, A.V. Environmental effects on inoculum quality of dormant rust uredospores. Phytopathology, v.69, n.10, p. 1106-8, 1979.

WILDERMUTH, G.B.; McNAMARA, R.B. Susceptibility of winter and summer crops to root and crown infection by Bipolaris sorokiniana. Plant Pathology, v.36, n.4, p. 481-91, 1987. 
WOOD, L.S. Relation of variation in Helminthosporium sativum to seedling blight of small grains. Phytopathology, v.52, n.6, p. 493-8, 1962.

YARWOOD, C.E. Uredospore production by Uromyces phaseoli. Phytopathology, v.51, n.1, p. 22-7, 1961.

YIRGOU, D.; CALDWELL, R.M. Stomatal penetration of wheat seedlings by stem and leaf rust: effect of light and carbon dioxide. Science, v.141, n.3577, p. 272-3, 1963.

YIRGOU, D.; CALDWELL, R.M. Stomatal penetration of wheat seedlings by stem and leaf rusts in relation to effects of carbon dioxide, light, and stomatal aperture. Phytopathology, v.58, n.4, p. 500-7, 1968.

ZADOKS, J.C. Systems analysis and the dynamics of epidemics. Phytopathology, v.61, n.6, p. 600-10, 1971.

ZADOKS, J.C. A quarter century of disease warning, 1958-1983. Plant Disease, v.68, n.4, p. 352-5, 1984.

ZADOKS, J.C.; RABBINGE, R. Modelling to a purpose. In: INGRAM, D.S.; WILLIAMS, P.H., ed. Advances in plant pathology. London: Academic Press, 1985. v.3: Mathematical modelling of crop disease. cap. 10, p. 23144.

ZADOKS, J.C.; SCHEIN, R.D. Epidemiology and plant disease management, the known and the needed. In: INTERNATIONAL CONGRESS OF PLANT PATHOLOGY, 3., Munich, 1978. Comparative epidemiology: a tool for better disease management; proceedings. Wageningen: Centre for Agricultural Publishing and Documentation, 1980. p. 1-17. 
ZADOKS, J.C.; CHANG, T.T.; KONZAK, C.F. A decimal code for the growth stages of cereals. Weed Research, v. 14, n.6, p. 415-21, 1974. 
mínima

média máxima

pluviometria $\bigcirc \quad$ URar média

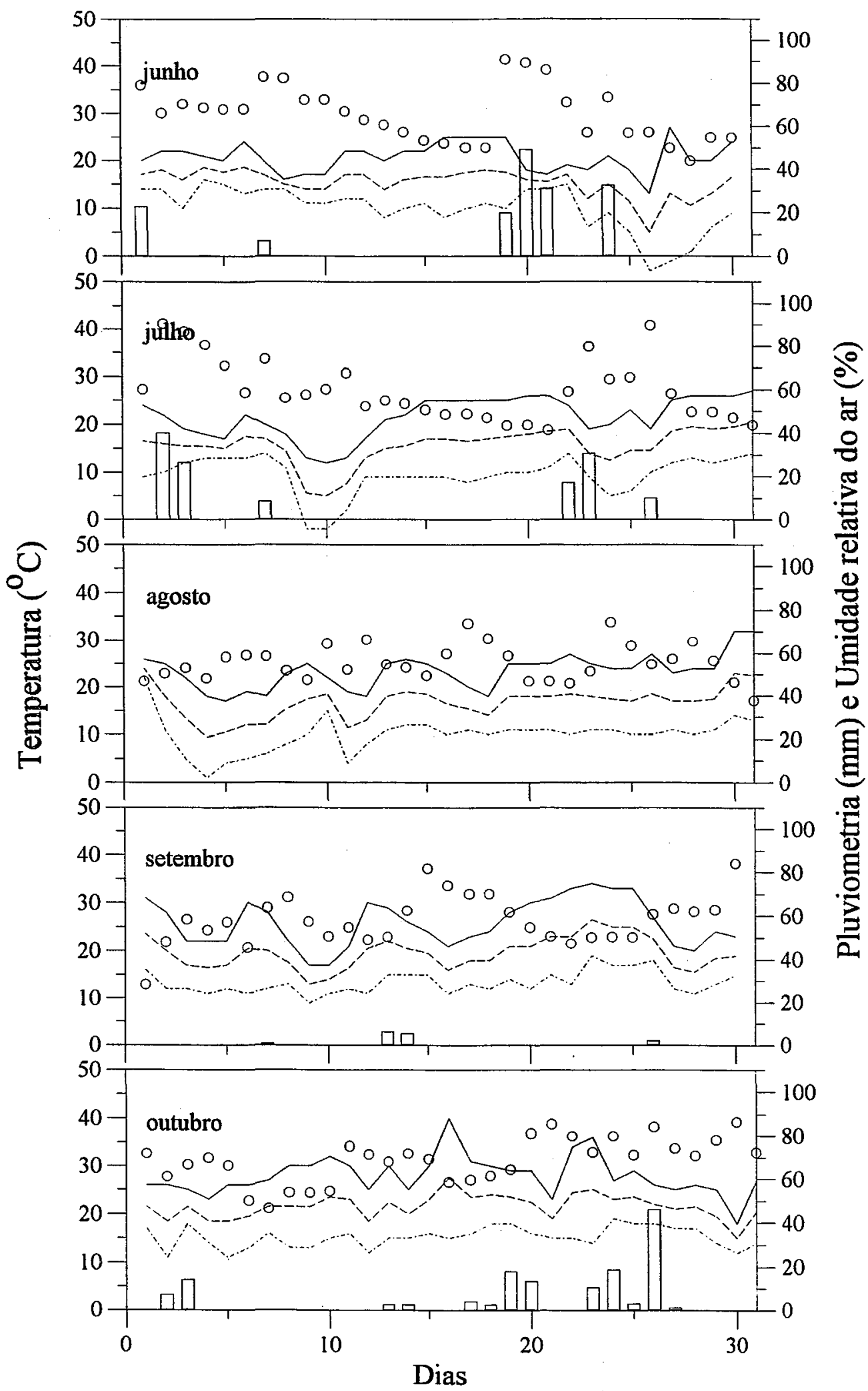

Apêndice 01. Dados climáticos (temperaturas mínima, média e máxima, umidade relativa do ar média e pluviometria) diários, obtidos no Campo Demonstrativo e Experimental da Cooperativa Agropecuária BATAVO, Ponta Grossa - PR, em 1994. 
mínima - máxima

\section{pluviometria O URar média}

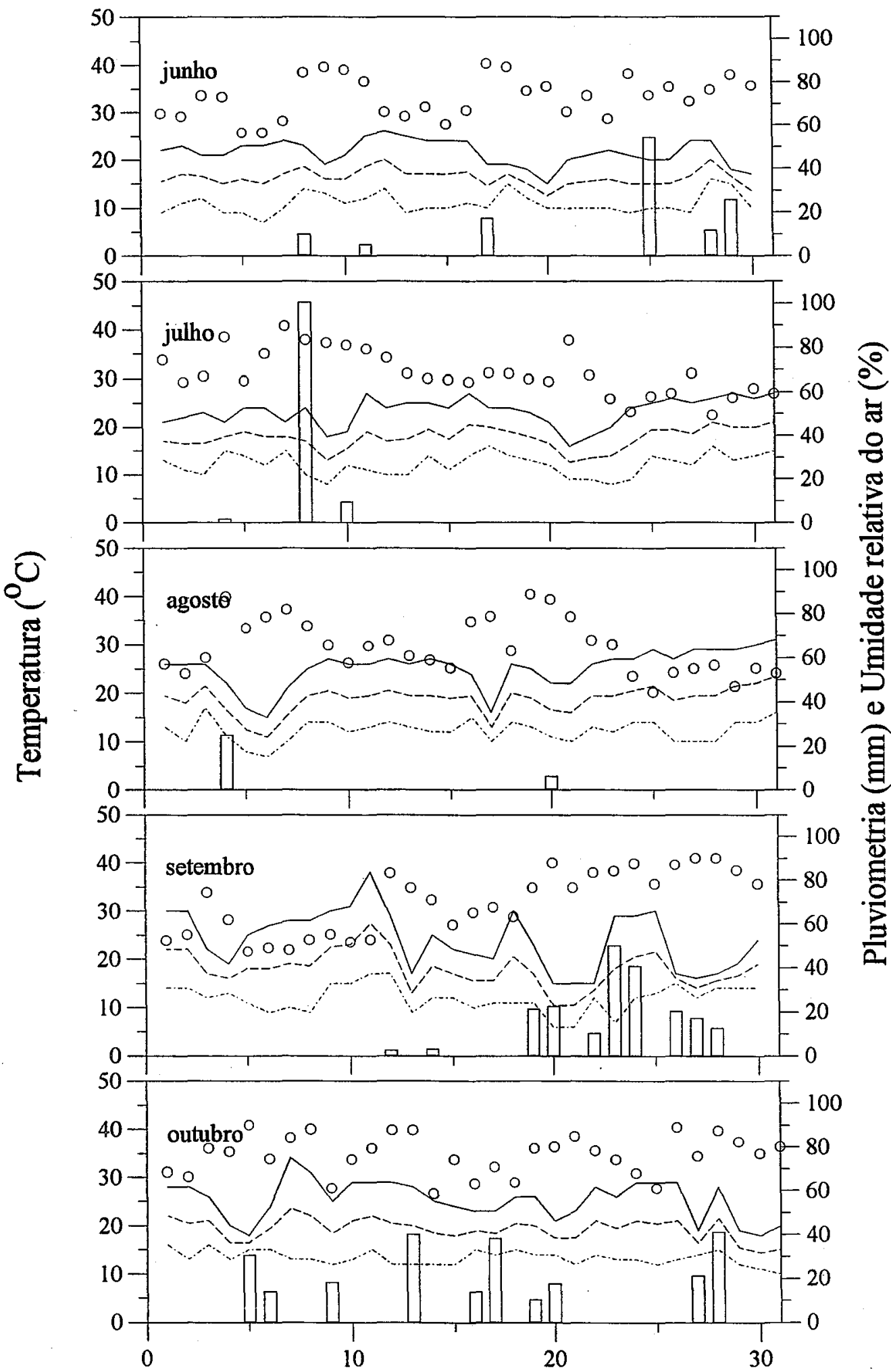

Dias

Apêndice 02. Dados climáticos (temperaturas mínima, média e máxima, umidade relativa do ar média e pluviometria) diários, obtidos no Campo Demonstrativo e Experimental da Cooperativa Agropecuária BATAVO, Ponta Grossa - PR, em 1995. 